Universidade de São Paulo

Faculdade de Odontologia de Ribeirão Preto

Departamento de Clínica Infantil

Denise de Souza Matos

Avaliação in vivo da formação óssea na sutura palatina mediana após irradiação com laser de baixa potência em pacientes submetidos a expansão rápida da maxila (ERM) 
Universidade de São Paulo

Faculdade de Odontologia de Ribeirão Preto

Departamento de Clínica Infantil

\section{Avaliação in vivo da formação óssea na sutura palatina mediana após irradiação com laser de baixa potência em pacientes submetidos a expansão rápida da maxila (ERM)}

Versão Corrigida

Tese apresentada ao Programa de Pós-graduação em Odontopediatria, área de concentração em Odontopediatria da Faculdade de Odontologia de Ribeirão Preto da Universidade de São Paulo, como requisito parcial para obtenção do título de Doutor em Ciências.

Aluna: Denise de Souza Matos

Orientador: Prof. Dr. Fábio Lourenço Romano

Ribeirão Preto 
Autorizo a reprodução total ou parcial deste trabalho, por qualquer meio convencional ou eletrônico, para fins de estudo e pesquisa, desde que citada a fonte.

Ficha Catalográfica

Matos, Denise Souza

Avaliação in vivo da formação óssea na sutura palatina mediana após irradiação com laser de baixa potência em pacientes submetidos a expansão rápida da maxila (ERM). Ribeirão Preto, 2016

Versão corrigida da Tese. A versão original se encontra disponível na Unidade que aloja o Programa.

103p. : il. ; $30 \mathrm{~cm}$

Tese de doutorado apresentada à Faculdade de Odontologia de Ribeirão Preto/USP - Área de Concentração: Odontopediatria.

Orientador: Prof. Dr. Fábio Lourenço Romano

1. Técnica de expansão palatina. 2. Terapia a laser de baixa potência.

3. Regeneração óssea. 4. Ortodontia interceptora 


\section{FOLHA DE APROVAÇÃO}

Matos DS. Avaliação in vivo da formação óssea na sutura palatina mediana após irradiação com laser de baixa potência em pacientes submetidos a expansão rápida da maxila (ERM).

Tese apresentada ao Programa de Pós-graduação em Odontopediatria, área de concentração em Odontopediatria da Faculdade de Odontologia de Ribeirão Preto da Universidade de São Paulo, como requisito parcial para obtenção do título de Doutor em Ciências.

Data da defesa:

\section{Banca Examinadora}

Prof. Dr.

Instituição:

Julgamento: Assinatura:

Prof. Dr.

Instituição:

Julgamento: Assinatura:

Prof. Dr. Instituição: Julgamento: Assinatura:

Prof. Dr. Instituição:

Julgamento: Assinatura:

Prof. Dr.

Instituição:

Julgamento: Assinatura: 


\section{DADOS CURRICULARES}

\section{Denise de Souza Matos}

Nascimento 24 de janeiro de 1987 - Patos de Minas/MG

Filiação Geraldo de Souza Magela

Diuza Geralda de Matos Souza

2005 - 2008 Graduação em Odontologia

Faculdade de Odontologia de Araraquara - UNESP

2011 - 2013 Especialização em Odontopediatria

Associação Odontológica de Ribeirão Preto - AORP

2011 - 2013 Mestrado em Ciências

Área de concentração: Odontopediatria

Faculdade de Odontologia de Ribeirão Preto - USP

Orientador: Prof. Dr. Fábio Lourenço Romano

Bolsa: CAPES

2013 - 2016 Doutorado em Ciências

Área de concentração: Odontopediatria

Faculdade de Odontologia de Ribeirão Preto - USP

Orientador: Prof. Dr. Fábio Lourenço Romano

Bolsa: CAPES 
Dedicatária 


\section{Dedicatóría}

$\mathcal{A} \mathcal{D} e u s$, responsável por todas as minhas conquistas. Obrigada por se fazer presente em todas as etapas da minha vida mesmo que em algumas delas eu não tenha percebido sua maravilhosa presença e influêncía. Obrigada por não ter me conduzido ao o caminho maís fácil e sim me acompanhado por esta longa estrada de aprendizado que é a vida e que ainda estou percorrendo com sua ajuda. Obrigada pelas oportunidades concedidas até hoje e pelo grande presente que é acordar todos os días com a certeza de estar na direção certa.

"Porque eu, o Senhor teu Deus, te tomo pela tua mão direita; e te digo: Nâa temas, eu te ajudo." 2saías 41:13

’̀ minha mãe Diuza, luz da nossa casa, guía das nossas vídas. Obrigada por todos os cuidados e ensinamentos. Por se preocupar com os minimos detalhes de tudo, por querer sempre o melhor em todos os aspectos e por me fazer buscar esse melhor. Seu carinho, incentivo e apoí foram muito importantes nessa etapa, e sua companfía e amizade essencial para me dar forças para continuar mesmo quando o desânimo se instalava. Mãe, com você aprendí que nossa famílía é o nosso bem maís precioso com quem podemos sempre contar.

Ao meu pai Geraldo, nosso herói e nosso porto seguro. Obrigada por me conduzír pelo caminho da honestidade com seus exemplos e por corrigir meus erros com amor. Hoje, grande parte de mím e das minhas conquistas foram inspiradas em você e na sua força. Obrigada por me fazer sentir segura e incentivar a voar cada vez mais alto, mesmo quando 
o medo e a dúvida me prendíam. Paí, minha determinação em tudo na vída vem da força que você faz eu sentir que tenho mesmo que no fundo eu sinta que não sou tão forte assím.

$\mathcal{A}$ vocês pai e mãe, dedíco toda a minha vida, todas as minha vitórias e todas as minhas conquistas!

"Foi o tempo que dedicastes à tua rosa que a fez tão importante." Antoine de Saint-Fxupéry 
Agradecimentas Especiais 


\section{Agradecimentos $\mathcal{E}_{\text {speciais }}$}

Ao meu orientador, Prof. Dr. Fábio Lourenço Romano, por todos os ensinamentos ao longo destes quase 6 anos de convívio. Obrigada pela orientação, paciência e principalmente pela preocupação com minha formação enquanto aluna, pesquísadora $e$ agora professora! Grande parte da profíssional que sou hoje é inspirada em você. Espero ser para meus alunos o que você foi para mim, e poder guía-los nos caminhos da Odontología com a competêncía e dedícação com a qual você me guiou. $\mathcal{A}$ você professor, desejo todo sucesso na sua caminhada e que mais alunos possam ter o privilégio da sua convívêncía e dos seus ensinamentos assim como eu tive. Nenhuma palavra sería suficiente para expressar minha admiração e respeito por você, mas deixo aqui meu agradecimento por tudo. Muito obrígada!

"Ensinar é um exercicio de imortalidade. De alguma forma continuamos a viver naqueles cujos olhos aprenderam a ver o mundo pela magia da nossa palavra. O professor, assim, não morre jamaís..” 


\section{Agradecimentos $\mathcal{E}_{\text {speciais }}$}

Aos pacientes e seus responsáveís. A vocês críanças, que me conquístaram, guardo uma lembrança especial de cada consulta, cada cartínha, cada desenho e cada bríncadeira que tivemos. Convíver durante o tratamento com vocês foi um presente e me fez ter certeza de ter escolhido o caminho certo quando entrei na Odontopediatría. Aos pais, irmãos maís velhos, tíos e avós que se disponibilizaram a acompanfí-los durante as consultas e entenderam a importâncía do comprometimento de cada um com este trabalho. Meu muito obrigada a todos vocês sem os quaís não tería sido possível a realização deste projeto e concretização deste sonho.

"Conheça todas as teorias, domine todas as técnicas, mas ao tocar uma alma humana, seja apenas outra alma humana.” Carl Gustav Jung 
Agradecimentas 


\section{Agradecimentos}

Profa. Dra. Regina Guenka Palma Dibb, pelas valiosas ideias e sugestões para elaboração e execução deste projeto. Sua ajuda foí essencial e sem dúvida seus ensinamentos contríbuiram para meu crescimento profissional.

Prof. Dr. Christiano de Oliveira Santos, pela disponíbilidade e atenção que dedicou a este trabalho, abraçando o projeto com total empenho. Sua dedicação a este trabalho agregou grande valor ao resultado final. Muito obrigada!

Profa. Dra. María Conceição Pereíra Saraiva, pelas longas conversas, pela paciêncía e pela dedicação durante a finalização deste trabalho. Obrigada professora pelo carinho, empenho e preocupação com este projeto.

Prof. Dr. Adílson Tomasin pela colaboração e por sempre se mostrar dísposto a ajudar e auxiliar no que fosse preciso. Obrigada!

Aos professores do departamento de Clinica Infantil, Aldevina Campos de Freitas, Alexandra Mussolino de Queiroz, Andiara De Rossi Daldegan, Fabrící Kitazono de Carvalho, José Tarcisio Lima Ferreira, Kranya Victoria Diaz Serrano, Léa Assed Bezerra da Silva, Maria Bernadete Sasso Stuani, Maria Crístina Borsato, Mirian Aiko Nakane Matsumoto, Paulo Nelson Filho, Raquel Assed Bezerra Segato, por serem exemplo de excelêncía no que fazem. 
Aos professores da Faculdade de Odontologia de Araraquara, que iniciaram a minha formação nesta profíssão e aos demaís professores com quem tive contato ao longo da vida. Cada um de vocês me acrescentaram algo e me fízeram crescer um pouquinho.

"Feliz aquele que transfere o que sabe e aprende o que ensina." Cora Coralina

Aos funcionários da Faculdade de Odontología de Ríbeirão Preto, de uma maneira especial os funcionários do departamento de Clínica Infantil: Carmo Euripedes T'erra Barretto, Carolina Paes Torres Mantovani, Fátima Aparecida Jacinto Daniel, Filomena Leli Placcití, Francísco Wanderley Garcia de Paula e Silva, Marco Antonio dos Santos, Marília Pacífico Lucisano, Matheus Morelli Zanela e Nilza Leticia Magalhães.

À secretáría da pós-graduação Micheli Cristina Leite Rovanholo, por estar sempre disposta a esclarecer nossas dúvidas e ajudar em qualquer situação. $\mathcal{A}$ você $\mathcal{M} i$, meu muito obrigada por tornar os días na pós-graduação maís leves com seu sorríso e sua atenção.

À secretáría do curso de especialízação em Ortodontía da Funorp Rosemary Alves de Sá, por toda a ajuda em várias situações ao longo desses quase 6 anos de pós-graduação. Rose, você é uma pessoa especial que me lembrarei sempre, obrigada pela amizade.

Aos funcionários das clínicas: Fernando Henrique Torrierí Codognotto, Karina Dadalt Quaglio, Vera do Nascimento Scandelai, Roberta da Silva Rute, José Neves do 
Nascimento e Tarciso Jose Rodrigues pela ajuda durante a execução da pesquisa, e por muitas vezes facilitar meu trabalho, sem o auxilio de vocês com certeza tería sido maís difícil. Meio muito obrigada de coração.

"A beleza não está na partida nem na chegada, mas na travessia."

Guimarães Rosa

Aos pós-graduandos do departamento de Clínica Infantil, em especial as amigas que desde o inicio fizeram parte dessa caminhada: Ana Caroline Fumes, Daniele Lucca Longo, Danielly Cunha Araújo, Driely Barreiros de Oliveira, Katharina Morant Holanda de Oliveira, Mariana Alencar Nemezio, Príscilla Coutinho Romualdo e Silvana Polizelí. A vocês amigas, desejo todo o sucesso desse mundo.

Às querílas amigas Juliana Faraoni Romano, Karla Orfelina Carpio Horta e María Gabriela Flores Bracho, obrigada pela amizade e pela ajuda em várías etapas deste trabalho.

Às amigas da graduação: Ana Elisa Plácido Moya, Cristina Pavan, Elaine Machado Pingueiro Okada, Emelly Aveiro, Ludmilla Faria, Juliana Rosado Valente e Margareth da Mata, amizades que levo para a vida toda.

Às melhores amigas que alguém podería ter: Carolini Satiko Tanaka e Sabrina Dornelas Mota. $\mathcal{A}$ amizade de vocês está no meu maís alto conceito e as consídero como irmãs. Obrigada pelas longas conversas e conselfos nos maís diversos assuntos, sempre estarei aqui quando precisarem, assím como sei que vocês são sempre estarão aí também. 
Aos funcionários do Faserv de Patos de Minas, em especial: Ana Ferreira, Égida Crístina, Eliane Barreto, Gislene Teixeira, Maria Flauzina Tiago e Simone Menegaz, obrigada pela amizade e pela compreensão. ’̇ Juliana Brito Valentín e Frederico Albuquerque meu mais sincero agradecimento pelo apoío e confiança.

"Todas as grandezas do mundo não valem um bom amigo." Voltaire

Aos meus irmãos Viviane de Souza Matos, Alexandre David de Souza Matos e meu cunhado Kleber José Moreira pelos inúmeros momentos de descontração e alegría. Vocês são meus grandes amigos e companheiros, obrigada por serem tão especiais e me fazerem sentir assim também.

Ao meu sobrinho João Gabriel Araújo Matos, alegría das nossas vidas e à Rosálía Aparecida da Silva Caíxeta, para sempre minha bombonzinha.

Aos tios, primos e familiares que torceram por essa vitória, meu muito obrígada!

"O amor verdadeiro comeşa lá onde não se espera maís nada em troca." Antoine de Saint-Exupéry

’̀ Universidade de São Paulo e à Faculdade de Odontologia de Ríbeirão Preto, na pessoa da atual diretora Profa. Dra. Léa Assed Bezerra da Silva e vice-diretor Prof. Dr. Arthur Belem Novaes Júnior. 
Ȧ seção de pós-graduação da Faculdade de Odontología de Ribeirão Preto.

À Capes (Coordenação de Aperfeiçoamento de Pessoal de Nivel Superior) pelo apoío.

"O sucesso nasce do querer, da determinação e persistência em se chegar a um objetivo. Mesmo não atingindo o alvo, quem busca e vence obstáculos, no minimo fará coisas admiráveis." José de Alencar 
Resuma 


\section{RESUMO}

\section{Matos, DS. Avaliação in vivo da formação óssea na sutura palatina mediana após irradiação com laser de baixa potência em pacientes submetidos a expansão rápida da maxila (ERM). [tese]. Ribeirão Preto: FORP-USP, 2016.}

O diagnóstico e tratamento precoce da mordida cruzada posterior esquelética ou atresia da maxila é extremamente importante e o uso de aparelhos disjuntores é o tratamento de escolha para estas maloclusões. A utilização de laser de baixa potência com a finalidade de estimular o reparo ósseo e diminuir a sensação dolorosa nesse tipo de tratamento vem sendo estudada e tem apresentado resultados promissores. O objetivo deste trabalho foi avaliar a ação osteoindutora do laser de baixa potência na sutura palatina mediana e os efeitos desta irradiação na sensação dolorosa em pacientes submetidos à expansão rápida da maxila (ERM) e o espaço nos arcos dentários antes e após o procedimento de ERM. Participaram da pesquisa 34 indivíduos sendo 16 no Grupo Controle e 18 no Grupo Experimental. Foram solicitadas documentações ortodônticas onde confirmou-se que os indivíduos apresentavam atresia esquelética de maxila e o plano de tratamento consistiu na utilização do aparelho Disjuntor Hyrax. Os pacientes do Grupo Experimental foram submetidos a irradiações com Laser de Diodo $(980 \mathrm{~nm}, 0,3 \mathrm{~W})$ a cada 5 dias durante a fase ativa do tratamento e 1 aplicação semanal durante 8 semanas após sobrecorreção e estabilização do parafuso expansor (fase passiva do tratamento) em seis pontos distribuídos bilateralmente à sutura palatina mediana, com duração de 10 segundos em cada ponto. Nos pacientes do Grupo Controle as irradiações foram realizadas no modo Standby do aparelho para caracterizar o efeito placebo. Durante o tratamento, os pacientes de ambos os grupos foram submetidos a exames radiográficos oclusais digitais nos seguintes tempos: estabilização do parafuso, 1 mês, 2 meses, 3 meses e 6 meses, padronizados com posicionador e penetrômetro. Para comparação entre as radiografias foi utilizado o programa Image J. A influência do laser na sensação dolorosa entre os grupos foi avaliada por meio de Escala Visual de Dor. Após a remoção do disjuntor, nova documentação ortodôntica foi solicitada para comparação do espaço nos arcos dentários antes e após o procedimento segundo o método de Moyers. Concordâncias inter e intra-examinadores foram avaliados por meio de teste de correlação intraclasses. Para a análise estatística da formação óssea foi utilizado modelo generalizado misto considerando o indivíduo como fator aleatório seguido do pós-teste de Tukey. Para a análise da dor também foi utilizado modelo generalizado misto para dados ordinais repetidos. Toda as análises foram realizadas no programa estatístico SAS 9.3. Os resultados mostraram que não houve diferença estatística entre os grupos com relação as variáveis analisadas, exceto em relação a análise de espaço no arco superior. Pode-se concluir que a terapia com laser de baixa potência nos parâmetros utilizados não influenciou a regeneração óssea e a sensibilidade dolorosa e que procedimento de ERM promoveu ganho de espaço no arco superior.

Palavras-chave: Técnica de expansão palatina, Terapia a laser de baixa potência, Regeneração óssea, Ortodontia interceptora. 


\section{ABSTRACT}

Matos, DS. Assessment of bone formation in vivo in median palatine suture after low power laser irradiation on patients undergoing rapid maxillary expansion (REM). [Thesis]. Ribeirão Preto: FORP-USP, 2016.

The diagnosis and early treatment of skeletal posterior cross bite or maxillary atresia is extremely important, and the use of disjunction appliances is the treatment of choice for these malocclusions. The use of low-power laser with the purpose of stimulating bone repair and diminishing the painful sensation in this type of treatment is being studied and has shown promising results. The aim of this work is to evaluate the osteoinductive action of low power laser on median palatine suture, and the effects of this radiation in the painful sensation in patients undergoing rapid maxillary expansion (RME). As a secondary objective, the dental arches space, before and after the procedure of RME, will be assessed. A total of 34 individuals participated in the research, being 16 in the Control Group and 18 in the Experimental Group. Orthodontic documentation was requested and they did confirm that the individuals had skeletal maxillary atresia, and the treatment plan consisted in the use of Hyrax disjunction appliance. Patients in the Experimental Group underwent Diode Laser irradiation (980nm, $0.3 \mathrm{~W}$ ) every 5 days during the active phase of treatment, and 8 weekly applications after overcorrection and stabilization of the expander screw (passive phase of treatment) in six points distributed bilaterally to the median palatine suture, for 10 seconds on each point. In patients of the Control Group irradiation was held in the Standby mode of the device to characterize the placebo effect. During treatment, patients in both groups underwent digital occlusal x-ray examinations according to the following timetable: stabilization of screw, 1 month, 2 months, 3 months and 6 months, patterned with positioner and penetrometer. The Image J program was used to compare the $\mathrm{x}$-rays. The influence of laser in painful sensation among the groups was evaluated through the Visual Scale of Pain. After removing the disjunction appliance, new orthodontic documentation was requested for comparison of dental arches space, before and after the procedure, according to Moyers's method. Inter and intra-examiners concordances were evaluated by means of intraclass correlation tests. The generalized mixed model was used, considering the individual as random factor followed by Tukey's post-test, for statistical analysis of bone formation. The mixed generalized model for ordinal repeated data was also used for the analysis of pain. All analyses were carried out in the statistical program SAS 9.3. The results showed that there was no statistical difference between the groups regarding the variables analyzed and that there was space gain in the upper arch. The paper concludes that the low-power laser therapy, in the parameters used, did not influence bone regeneration and the soreness; and that the RME procedure did promote space gain on the upper arch.

Keywords: Palatine expansion technique, low-power laser therapy, bone regeneration, interceptive Orthodontics. 
$\mathscr{L}_{\text {ista de Figuras }}$ 


\section{LISTA DE FIGURAS}

Figura 1: A - Atresia esquelética da maxila comprovada pelo estreitamento do arco e com distância intermolar $\leq 31 \mathrm{~mm}$. B - Desenho esquemático de mordida cruzada posterior lingual $\geq 4 \mathrm{~mm}$.

Figura 2: Aparelho Hyrax

Figura 3: $\quad$ A - Elástico de separação entre os segundos molares decíduos e os primeiros molares permanentes. B - Bandagem dos primeiros molares permanentes. C - Moldagem. D Transferência de bandas do paciente para a moldagem. E - Novo elástico de separação entre os segundos molares decíduos e os primeiros molares permanentes. F - Modelo de trabalho. G - Início da confeç̧ão do aparelho. H - Aparelho confeccionado sobre o modelo de trabalho. I - Aparelho cimentado e colado uma semana após a bandagem e moldagem

Figura 4: Final do procedimento de disjunção evidenciando sobrecorreção. A - Vista frontal, abertura de diastema; B - Vista oclusal, parafuso expansor imobilizado com resina acrílica; C - Vista lateral direita; D - Vista lateral esquerda.

Figura 5: Laser de diodo

Figura 6: Pontos de irradiação do laser próximos a sutura palatina mediana.

Figura 7: A - Ilustração da tomada radiográfica oclusal. B - Radiografia oclusal digital padronizada.......

Figura 8: $\quad$ Regiões de interesse (ROIs) delimitadas no centro da sutura palatina após abertura (ROI 1) e no degrau central do penetrômetro (ROI 2) para comparação e obtenção do valor de pixel ajustado.

Figura 9: Cronograma de aplicações do laser (L) e realização das tomadas radiográficas oclusais (R).

Figura 10: Escala visual analógica de dor.

Figura 11: Registro do diâmetro mesiodistal dos incisivos na ficha da ADM

Figura 12: Previsão do tamanho dos diâmetros combinados dos caninos e pré-molares por hemiarco.

Figura 13: Cálculo da discrepância de modelos por hemiarco para os lados direito e esquerdo..........

Figura 14: Ficha de Análise da Dentição Mista com tabela de proabilidade de Moyers.

Figura 15: A,B,C- Correção das linhas médias; $\mathbf{D}, \mathbf{E}, \mathbf{F}, \mathbf{G}-$ Mensuração do diâmetro M-D dos incisivos inferiores; H- Espaço necessário para alinhamento dos incisivos; I,JMensuração do espaço avaliado após alinhamento dos incisivos.

Figura 16: Fluxograma ilustrando a metodologia do estudo.

Figura 17: Variação de desvio padrão das radiografias realizadas durante tratamento de ERM para os grupos controle e experimental ao longo dos seis meses de acompanhamento, com intervalo de confiança de $95 \%$ em cada tempo. 
Figura 18: Trajetórias individuais de formação óssea (valor de pixel) durante tratamento de ERM para gupos controle e experimental durante seis meses de tratamento.

Figura 19: Formação óssea (valor de pixel) durante seis meses de tratamento com ERM para grupos controle e experimental com intervalos de confiança de $95 \%$, sem o ajuste da idade.

Figura 20: Formação óssea (valor de pixel) durante seis meses de tratamento com ERM para grupos controle e experimental com intervalos de confiança de 95\%, após o ajuste da idade.

65

Figura 21: Presença de dor entre os grupos ao longo da fase ativa do tratamento. 68

Figura 22: Evolução da dor moderada entre os grupos 68

Figura 23: Evolução da dor intensa entre os grupos 68

Figura 24: Ilustração gráfica mostrando a avaliação de espaço. Arcada superior apresentou ganho de espaço evidenciado pela ADM antes e após disjunção e a arcada inferior manteve-se constante com relação ao espaço já existente previamente ao tratamento. 
Lista de Tabelas 


\section{LISTA DE TABELAS}

Tabela 1: Critérios de inclusão e exclusão da amostra............................................................... 45

Tabela 2: Desvio padrão das imagens radiográficas realizadas durante tratamento de ERM para os $\mathbf{6 3}$ grupos controle e experimental ao longo dos seis meses de acompanhamento.

Tabela 3: Formação óssea sem o ajuste pela idade............................................................... $\quad 65$

Tabela 4: Formação óssea ajustada pela idade........................................................................ $\quad 66$

Tabela 5: Médias inicial e final para cada quadrante................................................................... 69

Tabela 6: Médias inicial e final divididas pelas arcadas superior e inferior....................................... $\quad 69$ 
Sumaria 


\section{SUMÁRIO}

1. INTRODUÇÃO

2. PROPOSIÇÃo

3. MATERIAL e MÉtodos

3.1 Seleção dos pacientes

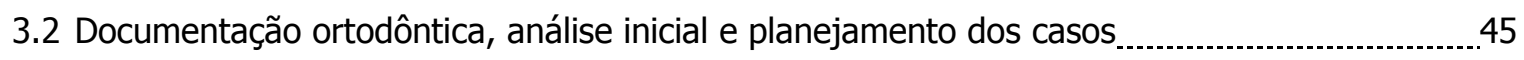

3.3 Procedimento de ERM

3.4 Irradiação do Laser

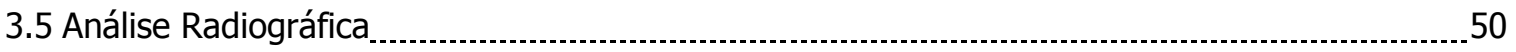

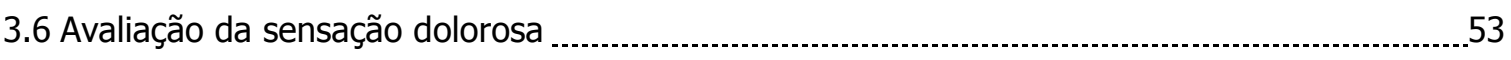

3.7 Análise da Dentição Mista (ADM)

3.7.1 Procedimento no arco inferior

3.7.2 Procedimento no arco superior

3.8 Análise Estatística.

4. RESULTADOS

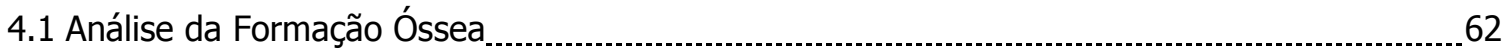

4.1.1 Descrição da amostra.

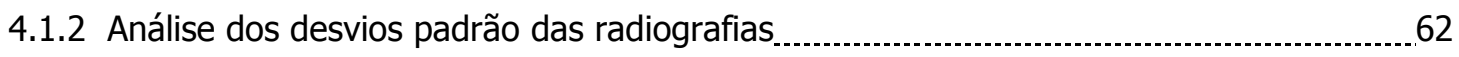

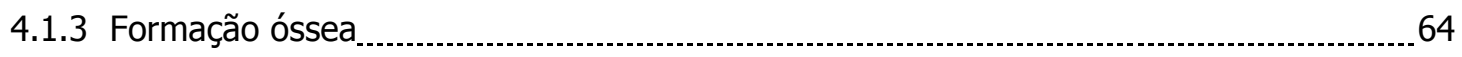

4.2 Sensação dolorosa.

4.3 Análise da dentição mista (ADM)

5. DISCUSSÃO

6. CONCLUSÃO

REFERÊNCIAS

ANEXOS 
1. Intraducãa 


\section{INTRODUÇÃO}

O principal objetivo da Ortodontia desde a antiguidade tem sido restabelecer a oclusão normal. Relatos de tentativas de correção das chamadas "irregularidades dentárias" como má posição de dentes e maloclusões, foram encontrados e datados a cerca de 1000 anos a.C. A aparência ruim causada pelo posicionamento dentário incorreto já se mostrava um problema para gregos e etruscos que desenvolveram aparelhos ortodônticos primitivos. Este foi o primeiro registro da utilização destes dispositivos com finalidade de correção para tal problema mostrando assim uma preocupação crescente. Mais tarde, em meados de 25 a.C., um escritor romano chegou a afirmar a possibilidade de movimentação dentária a partir da pressão digital para que um dente mal posicionado alcançasse sua posição correta (Weinberger, 1926; Vilella, 2007).

Após longo período de declínio durante a idade média que envolveu todas as ciências, a Odontologia voltou a ficar em evidência, embora com muitas dificuldades envolvendo os profissionais que a praticavam. Como a Odontologia era até então praticada e ensinada em escolas de Medicina e muitas vezes os alunos não demostravam interesse, Hayden (1769-1844) e Harris (1806-1860), dois praticantes da Odontologia, sendo este último médico de formação treinado pelo Hayden, decidiram em 1840 fundar a primeira escola de Odontologia do mundo, a Baltimore College of Dental Surgery (Maryland) (Ring, 1993; Vilella, 2007).

Com o avanço no ensino da Odontologia e à medida que ela se desenvolvia, uma grande variedade de aparelhos utilizados para correção de posições dentárias incorretas foram desenvolvidos e descritos, sendo utilizados pelos dentistas da época e abrindo para a Ortodontia novas possibilidades de tratamentos e de pesquisas que buscavam melhorar e aprimorar sua prática (Ring, 1993; Vilella, 2007).

Neste contexto, surge nos Estados Unidos, um nome que influenciou profundamente o desenvolvimento da Ortodontia no mundo. Edward Hartley Angle (18551930) foi o responsável por estruturar a Ortodontia da maneira como conhecemos hoje, classificando as maloclusões e estabelecendo normas e tratamentos para elas. Grande pesquisador, dedicou-se a estudar as movimentações dentárias e repassar este conhecimento aos seus alunos que se tornariam mais tarde grandes nomes da Ortodontia, entre eles Charles Tweed. Angle colocou a Ortodontia como a primeira especialidade da Odontologia em 1900 e seus artigos e publicações são ainda hoje referência para o tratamento ortodôntico, ficando conhecido como o "Pai da Ortodontia" (Hahn, 1965; Wahl, 2005; Vilella, 2007). 
A Ortodontia atual se baseia em técnicas e filosofias sedimentados em conhecimentos já consagrados, entretanto novos métodos tem mostrado resultados promissores. A cada dia, a preocupação em intervir precocemente em diversos tipos de maloclusões a fim de evitar agravamentos futuros tem aumentado e se tornado foco de muitos profissionais. Segundo McNamara, o principal objetivo de uma intervenção precoce é a correção de um desequilíbrio existente ou de um desenvolvimento incorreto dentoalveolar, esquelético e muscular, melhorando assim as condições orofaciais antes que termine a erupção da dentição permanente. Ainda segundo o autor, quando se inicia o tratamento ortodôntico ou ortopédico ainda na infância, a possibilidade de redução da complexidade de um tratamento ortodôntico envolvendo extrações de dentes permanentes e cirurgias ortognáticas na idade adulta é evidente. Ou seja, havendo a possibilidade de intervir precocemente em qualquer tipo de maloclusão, esta seria sem dúvida a melhor opção, uma vez que é mais lógico prevenir a ocorrência de uma anormalidade, do que esperar que ela se desenvolva para depois corrigi-la (McNamara, 1996).

Alguns aspectos influenciam na decisão dos profissionais em intervir durante a fase de dentição decídua e mista ou aguardar até a fase de dentição permanente. Fatores como o tipo de maloclusão apresentada, fase de crescimento em que o paciente se encontra, benefícios a longo prazo que facilitem ou dispensem o tratamento ortodôntico corretivo posterior, colaboração dos pais e do paciente, maturidade para aceitar o tratamento e cooperar com o mesmo (Da Silva Filho et al., 1995; McNamara, 1996; White 1998; Dugoni e Aubert, 2006). Alguns casos específicos requerem diagnóstico e tratamento precoce a fim de evitar alterações ósseas irreversíveis. Os casos de atresia esquelética da maxila é um bom exemplo onde a Ortodontia interceptora tem atuado com ótimos resultados (Da Silva Filho et al., 1995; McNamara, 1996; Da Silva Filho et al., 2000).

Considerando que o crescimento transversal dos arcos dentários é o primeiro a cessar, é de extrema importância o diagnóstico e tratamento precoce das mordidas cruzadas posteriores e da atresia esquelética da maxila, a fim de evitar agravamentos e alterações que posteriormente serão corrigidas com procedimentos cirúrgicos (Haas, 1965 e 1970; Bishara e Staley, 1987; McNamara, 2000; McNamara et al., 2003).

A correção das mordidas cruzadas posteriores decorrentes da atresia esquelética maxilar é indicada principalmente antes do surto máximo de crescimento puberal, que ocorre aproximadamente aos 10-11 anos para as meninas e aos 12-13 anos para os meninos (Bishara e Staley, 1987; Graber \& Vanarsdall, 1996; Proffit et al., 2007). Nesta faixa etária, a expansão rápida da maxila torna-se facilitada, pois ainda não houve a ossificação da sutura palatina mediana. Com o aumento da idade, esta sutura tende a tornar-se total ou 
parcialmente fusionada, dificultando o processo de disjunção palatina. Após o fechamento das suturas ou da finalização do crescimento transversal, a expansão ortopédica da maxila somente com o uso de aparelhos disjuntores é contra indicada e na maioria dos casos pode ocorrer fracasso do procedimento, causando desconforto e dor ao paciente (Betts et. al, 1995; Handelman, 1997; Handelman et al., 2000). As análises radiográficas da sutura palatina mediana são fundamentais para o correto planejamento e controle do tratamento, com finalidade de verificar a viabilidade e a possibilidade de abertura desta sutura. As radiografias oclusais, descritas pela primeira vez por Simpson em 1916, são as mais indicadas para este diagnóstico (Alvares e Tavano, 2002; De Melo et al., 2013). Neste campo, as radiografias digitais tem ganhado espaço por apresentarem melhor qualidade das imagens, menor tempo de exposição, maior conforto e segurança aos pacientes (Versteeg et al., 1997; Hayakawa et al., 1997; Yoshiura et al., 1999a; Yoshiura et al., 1999b; Berkhout et al., 2003; Anissi e Geibel, 2014).

O tratamento da atresia maxilar esquelética requer o aumento das dimensões transversais da arcada superior com o auxílio de aparelhos disjuntores. O primeiro registro de tratamento utilizando a expansão ortopédica da maxila é de 1860 quando Angell, em São Francisco nos Estados Unidos propôs sua utilização por meio de um aparelho primitivo em um caso de atresia da maxila em paciente adulto (Angell, 1860). Anos mais tarde, a Ortodontia americana recusou o tratamento de expansão ortopédica proposto por Angell tomando por base a ideia propagada por Angle (Angle, 1910) que afirmava que o crescimento ósseo intersticial era impulsionado pela movimentação ortodôntica. Na Europa o tratamento utilizando expansores para aumento transversal da maxila encontrou forças em alguns grupos de pesquisa (Derichsweiler, 1953; Korkhaus, 1960) que comprovaram sua eficácia e eficiência. Os resultados apresentados por grupos de pesquisa europeus incentivaram os pesquisadores americanos a trabalharem experimentalmente com aparelhos que promoviam a expansão ortopédica da maxila e estabeleceram novos caminhos na Ortodontia americana.

Grande parte do reconhecimento da técnica de expansão da maxila se deve aos estudos e trabalhos publicados por Haas (Haas, 1961; Haas, 1965; Haas, 1970; Haas, 1973; Haas, 1980) que foi capaz de demonstrar por meio de estudos histológicos, cefalométricos e clínicos, os resultados favoráveis desta técnica. Hoje, inúmeros estudos demostram e sedimentam a importância da técnica de expansão por meio de aparelhos disjuntores na correção das discrepâncias transversais da maxila (Da Silva et al., 1995; Da Silva et al., 2000; Weissheimer et al., 2011; Cepera et al., 2012; Luebbert et al., 2016). 
Os aparelhos mais comumente utilizados atualmente são: disjuntor de Haas, com ancoragem dentomuco suportada, o disjuntor Hyrax proposto por Biederman em 1968, que é dento suportado, e o disjuntor de McNamara também dento suportado (Haas, 1961; Biederman, 1968; McNamara e Brudon, 1993).

O aparelho proposto por Haas em 1961 e que levou seu nome, é composto parte por estrutura metálica rígida construída utilizando fio $1,0 \mathrm{~mm}$, e parte por resina acrílica sobreposta ao palato. A estrutura metálica é soldada a bandas ortodônticas que são posteriormente cimentadas aos primeiros molares permanentes. $O$ apoio em acrílico na região da mucosa palatina deve apresentar leve contato sem agredir áreas como gengiva marginal livre e rugosidades palatinas (Haas, 1961).

O disjuntor Hyrax, é constituído por estrutura metálica, com fio $1,0 \mathrm{~mm}$, que contorna as faces palatinas e vestibulares de pré-molares e molares sendo soldada às bandas ortodônticas. Para dentição mista, esse aparelho foi modificado de maneira que, a estrutura metálica contorne as faces palatinas e vestibulares de molares permanentes, molares e caninos decíduos. A estrutura metálica é soldada às bandas que posteriormente são cimentadas nos primeiros molares permanentes e o fio ortodôntico colado com compósito nos caninos decíduos. O parafuso expansor, elemento ativo do aparelho, é posicionado na região da rafe palatina mediana, centralmente no arco dentário, na região de segundos pré-molares ou segundos molares decíduos, o mais próximo possível da profundidade do palato e unindo as duas partes do aparelho. Este aparelho é conhecido por facilitar a higienização do paciente uma vez que não possui acrílico na região do palato (Biederman, 1968).

O disjuntor McNamara por sua vez, também é constituído por estrutura metálica que contorna as faces palatinas e vestibulares de pré-molares e molares mas diferente dos outros aparelhos disjuntores que possuem bandas ortodônticas, este possui cobertura oclusal de acrílico nos dentes posteriores. Esta cobertura oclusal com cerca de $3 \mathrm{~mm}$ de acrílico, atua como um batente de mordida posterior, inibindo a extrusão dos molares durante o tratamento, sendo indicado para pacientes com tendência de crescimento vertical (McNamara e Brudon, 1993).

O procedimento clínico de expansão rápida da maxila inclui uma fase ativa, que libera forças transversais com a finalidade de promover a abertura da sutura palatina mediana, e outra passiva, para contenção. A ativação do aparelho deverá ser interrompida quando houver sobrecorreção da oclusão posterior com as vertentes vestibulares das cúspides palatinas dos dentes posteriores superiores ocluindo nas vertentes linguais das cúspides vestibulares dos dentes posteriores inferiores. Neste momento, o parafuso 
expansor é imobilizado e o aparelho deverá permanecer passivo na cavidade bucal por aproximadamente 6 meses para neoformação óssea na sutura palatina (McNamara, 1996; Simões et al., 2003; Da Silva Filho et al., 2006; Da Silva Filho et al., 2008; Lione et al., 2008; Martins et al., 2009, Franchi et al., 2010; De Melo et al., 2013). Nesta fase, novo osso é formado no espaço da sutura e a expansão estará consolidada, diminuindo assim o risco de recidivas (Inoue et al., 1970; Melsen, 1972; Da Silva Filho, 2003; Cepera et al., 2008; De Melo et al., 2013). Alguns autores defendem a necessidade de retenção do aparelho na cavidade bucal por um período mínimo de 3 meses, afirmando que períodos de retenção inferiores a 6 meses são capazes de promover reorganização óssea necessária para evitar recidiva (Angell, 1860; Haas, 1961; Haas, 1965; Ekastrom et al., 1977; Ten Cate et al., 1977). Há ainda quem preconize o uso de contenção por placa palatina removível por um período mínimo de 6 meses após a remoção do aparelho aos 3 meses da fase passiva (Bell, 1982; Capelozza Filho e da Silva Filho, 1997a; Capelozza Filho e da Silva Filho, 1997b).

O processo de formação ou regeneração óssea pós disjunção é complexo. De maneira geral, em qualquer tecido ósseo, a matriz é inicialmente secretada pelos osteoblastos que são derivados de células mesenquimais primitivas, chamadas células osteoprogenitoras. O estímulo para o funcionamento e produção de osteoblastos depende de inúmeros fatores genéticos ou locais e uma vez diferenciadas, estas células (osteoblastos) passam a sintetizar e secretar a matriz orgânica que dará origem ao futuro osso. Os osteoblastos também funcionam como transmissores de sinais para a ativação da remodelação óssea atuando como receptores de fatores que irão regular a função local das células ósseas estimulando a proliferação, diferenciação e produção de proteínas da matriz extracelular. Os osteoclastos, por sua vez, originam-se do sistema hematopoiético do osso trabecular que dão origem também as células da linhagem dos monócitos e macrófagos e são elas as responsáveis pela reabsorção da matriz que ocorre na remodelação óssea.

Existe ainda entre as células responsáveis pela formação e remodelação óssea, os osteócitos, que apresentam a mesma origem dos osteoblasto. Essas células se localizam em lacunas dentro da matriz óssea e além de auxiliarem com a sua nutrição, eles contribuem para a homeostase do cálcio sanguíneo. Os osteócitos possuem ainda uma função mecanosensora onde em decorrência de deformação óssea, estas células enviam mensagens as células em repouso, que desencadeiam resposta e modulam a atividade de remodelação óssea dos osteoblastos e osteoclastos. Este complexo processo conta ainda com o sistema RANK/RANK-L/OPG que orquestra todo o mecanismo (Katchburian e Arana, 2012; Junqueira e Carneiro, 2013). 
Durante as ativações do aparelho disjuntor em sua fase ativa, pode ocorrer sintomatologia dolorosa que atinge seu pico imediatamente após cada ativação e declina minutos depois. Normalmente a queixa dos pacientes ocorre nos primeiros dias de ativação e a medida que a sutura se abre a sintomatologia diminui sensivelmente. Pacientes mais jovens costumam apresentar menor sensibilidade a dor durante o procedimento, o que pode estar relacionado com a facilidade de abertura da sutura pelo fato de esta ainda não ter iniciado o processo de consolidação (Haas, 1965; Haas, 1970, Handelman, 1997; Handelman et al., 2000; Needleman et al., 2000; Baldini et al., 2015). Estudo em camundongos comprovou ativação de estruturas do cérebro relacionadas com a percepção de estímulos dolorosos durante a disjunção (Joviliano et al., 2008), e níveis de cortisol aumentado foram encontrados em crianças submetidas ao procedimento de disjunção, indicando estresse e ansiedade causados pelo tratamento (Gecgelen et al., 2012). As escalas visuais analógicas são instrumentos utilizados para estimar a intensidade da dor e são indicadas por serem de fácil e rápida aplicação, sendo uma forma adequada e validada para qualificar esta sensação. Por ser um instrumento unidimensional ela analisa apenas a intensidade da dor, desconsiderando quaisquer outros aspectos que possam estar relacionados a ela (Gift, 1989; Mottola, 1993; Garra et al., 2013; Baldini et al., 2015).

O uso de disjuntores pode trazer outros inconvenientes além da sensação dolorosa. Problemas na adaptação envolvendo dificuldades na alimentação e alterações na pronúncia de algumas palavras são normalmente relatadas pelos pacientes e seus responsáveis nos primeiros dias (Matsuoka et al., 2006; Navarro et al., 2013). A dificuldade de higienização é outra preocupação constante que pode levar ao aumento do risco à cárie caso o paciente não seja acompanhado e orientado pelo profissional responsável (Lundström e Hamp, 1980; Jenatschke et al., 2001).

O acompanhamento do paciente submetido ao procedimento de expansão rápida da maxila é extremamente importante. Durante a fase ativa do tratamento o paciente deve ser acompanhado semanalmente, devendo o profissional estar à disposição caso ocorra qualquer inconveniente neste período. Na fase passiva ou durante a contenção, o paciente passa a ser acompanhado uma vez por mês e neste momento avaliar a higiene, o risco à cárie e a ocorrência de lesões em tecidos moles resultante do uso do aparelho é essencial para o bom andamento do tratamento (Schuster et al., 2005; Consolaro et al., 2009; Maia et al., 2011).

Algumas alterações são frequentemente observadas após a disjunção. O sinal clássico de abertura da sutura palatina é o diastema entre os incisivos superiores que tende a fechar ao longo da fase passiva (fase de contenção) do tratamento (Haas, 1965; Bishara e Staley, 1987, Da Silva Filho et al., 1995). No arco superior as mudanças são mais evidentes 
e diversos estudos apontam o ligeiro deslocamento da maxila para frente e para baixo, aumento das larguras interorbital, maxilar e nasal (Haas, 1970; Da Silva Filho et al., 1995; Chung e Font, 2004, Lagravère et al., 2006; Izuka et al., 2015) e aumento da permeabilidade nasal (Wertz, 1968; Haas, 1970; Da Silva Filho et al., 1995). Pode-se observar uma inclinação vertibular dos molares superiores acompanhada por discreta extrusão além de palato-versão e extrusão dos incisivos superiores em alguns casos (Bishara e Staley, 1987; Christie et al., 2010).

No arco inferior, é frequente observar rotação para baixo e para trás da mandíbula, devendo o procedimento ser cuidadosamente realizado em pacientes verticais e com tendência a mordida aberta. Esse deslocamento da mandíbula leva ao aumento do ângulo do plano mandibular e do eixo $\mathrm{Y}$ de crescimento, bem como o aumento da altura facial anterior (Bishara e Staley, 1987; Chung e Font, 2004). Alguns autores afirmam que as alterações verticais encontradas após os tratamento, mesmo sendo estatisticamente significantes, são transitórias, não devendo ser um problema para os pacientes com tendências de crescimento vertical (Velázquez et al., 1996; Chang et al., 1997; Lagravère et al., 2005; Garib et al., 2007; Lione et al., 2013).

A falta de espaço no arco superior na fase de dentição mista pode ser decorrente de muitos fatores, inclusive da atresia esquelética da maxila. A instalação e ativação de aparelhos disjuntores contribui para o ganho de perímetro no arco superior por meio do aumento de suas dimensões transversais (Bishara e Staley, 1987, Adkins et al., 1990; Lagravère et al., 2010; Lione et al., 2013; Perillo et al., 2014; D'Souza et al., 2015). A Análise da Dentição Mista (ADM) segundo Moyers (1991) propõe avaliar a quantidade de espaço disponível para os dentes permanentes sucessores tanto para o arco superior como para o inferior e os ajustes necessários para correta oclusão após irrompimento destes dentes, sendo um importante instrumento para quantificar a falta ou não de espaço nos arcos dentários. Outro dado diagnóstico importante é a distância intermolar que segundo McNamara (2000), um valor menor ou igual a 31mm para crianças de 6 a 12 anos, caracteriza atresia esquelética da maxila, sendo uma indicação para ERM. O aumento do perímetro do arco superior após ERM e consequente aumento da distância intermolar é observado em diversos estudos apresentando boa estabilidade a longo prazo (Bishara e Staley, 1987; McNamara et al., 2003; Mutinelli et al., 2008; Domann et al., 2011; Wong et al., 2011).

Alterações no perímetro do arco inferior após o procedimento de disjunção ainda são pouco estudadas. Alguns estudos indicam que há aumento significativo com um efeito clínico importante e positivo nas dimensões mandibulares após ERM (Baccetti et al., 2001; 
McNamara et al., 2003; Grassia et al., 2015; Ugolini et al., 2016). Outros autores afirmam que não ocorrem alterações nas dimensões do arco mandibular após ERM ou que estas não são estatisticamente significantes (Bishara e Staley, 1987; Lagravère et al., 2006).

$\mathrm{O}$ uso do laser (Light Amplification by Stimulated Emission of Radiation) nas mais diversas áreas saúde tem crescido rapidamente nas últimas décadas. A Medicina e a Odontologia tem se beneficiado desta ascensão que trouxe avanços no tratamento de diferentes enfermidades. Em 1960, Theodore Maiman foi o responsável pela primeira emissão estimulada de radiação e consequentemente o desenvolvimento do primeiro aparelho de laser. O pesquisador utilizou como meio ativo uma roda de Rubi que por meio da excitação com pontos luminosos intensos resultou na emissão do primeiro raio laser com espectro vermelho, abrindo assim caminhos para a criação dos inúmeros tipos de laser com suas distintas finalidades existentes nos dias de hoje (Brugnera Júnior et al., 1991; Pinheiro et al., 2010; Verma et al., 2012).

O laser é uma forma de radiação não ionizante, extremamente concentrada e não invasiva na maioria dos comprimentos de ondas utilizados. Quando utilizado com finalidade terapêutica é muito bem tolerado pelas tecidos e sua interação resulta, de acordo com o tipo de laser, em efeitos térmicos, fotoquímicos e não lineares. Os comprimentos de onda utilizados no laser de forma terapêutica não apresentam efeitos mutagênicos e podem ser utilizados repetidamente sem riscos, desde que respeitados as normas de biossegurança exigidas para cada aparelho (Brugnera Júnior et al., 1991; Pinheiro et al., 2010, Verma et al., 2012).

O primeiro estudo na Odontologia envolvendo o uso do laser foi o de Stern e Sogannaes (1964) que observaram após a irradiação do laser de Rubi em esmalte e dentina, uma redução da permeabilidade dentinária e desmineralização do esmalte. A partir daí começaram a surgir questionamentos acerca do calor gerado pelo aparelho e sua influência negativa sobre polpa dental (Goldman et al., 1965; Adrian et al., 1971; Adrian, 1977). Iniciou-se então uma série de pesquisas nas mais diversas áreas da Odontologia e com os mais variados tipos de aparelhos afim de estabelecer parâmetros para a utilização segura do equipamento (Fisher e Frame, 1984; Stewart et al., 1985; Frame, 1985; Wigdor et al., 1995; Strauss, 2000; Sulieman, 2005).

Existem muitos meios ativos para o desenvolvimento de equipamentos de lasers e estes podem ser sólidos (Rubi), gasoso $\left(\mathrm{CO}_{2}\right.$, $\left.\mathrm{He}-\mathrm{Ne}, \mathrm{Ar}\right)$, semicondutor (Diodo, AsGaAl, AsGa), semissólido (Nd-YAG, Er-YAG, YAP), excímero ( $\mathrm{KrF}, \mathrm{XeCl})$ ou líquidos (rodamine e cumarina). Os meios ativos resultam em diferentes tipos de radiação e cada uma possui um determinado efeito nos tecidos. De acordo com o meio ativo e o comprimento de onda que o 
aparelho emite, os aparelhos podem ser classificados em lasers de baixa potência, quando este não possui capacidade de remover tecidos ou materiais, ou seja, não é capaz de promover ablação, e os lasers de alta potência ou lasers cirúrgicos, capazes de promover ablação (Brugnera Júnior et al., 1991; Pinheiro et al., 2010, Carroll et al., 2014).

Na Odontologia, a utilização de lasers se faz presentes nas diversas especialidades inclusive na Ortodontia onde tem trazido avanços para os tratamentos e vantagens aos pacientes, embora estes benefícios ainda não estejam bem difundidos entre os profissionais da área. Dentre as diversas finalidades e utilizações do laser na Ortodontia podemos citar: descolagem de bráquetes cerâmicos (Matos, 2013a; Macri et al., 2015), odontalgias decorrentes da movimentação ortodôntica e outros procedimentos que provoquem dor (Lim et al., 1995; Turhani et al., 2006; Tortamano et al., 2009; Doshi-Mehta e Bhad-Patil, 2012), facilitação da movimentação ortodôntica acelerando esse processo (Carvalho-Lobato et al., 2014), polimerização da resina durante a colagem de bráquetes (Pinto et al, 2011; Matos, 2013b), holografia para análise tridimensional dos modelos de gesso (Romeo et al., 1995), scanner a laser que permite a obtenção de imagens tridimensionais do paciente e auxiliam no planejamento do tratamento (Kusnoto e Evans, 2002), diagnóstico e prevenção de lesões de mancha branca em pacientes de alto risco a cárie (Stangler et al., 2013; Lacerda et al., 2014; Yassaei, et al., 2014; Bahrololoomi et al., 2015; Mansour et al., 2016), diminuição do risco à cárie por meio da terapia fotodinâmica (Rajesh et al., 2011; Baptista et al., 2012; Hakimiha et al., 2014), cicatrização de úlceras traumáticas decorrentes do tratamento ortodôntico (Lilge et al., 2000; Morton et al., 2015), interação ortodontia/periodontia em pacientes que apresentem problemas periodontais concomitantes ao tratamento ortodôntico (Glez et al., 2010; Pejcic et al., 2010; Rajesh et al., 2011) e por fim, na reparação óssea em pacientes submetidos à expansão rápida da maxila (Cepera et al., 2012).

A utilização de laser no reparo ósseo após expansão rápida da maxila tem atraído atenção da comunidade científica por ser alternativa promissora para acelerar a regeneração do tecido após a abertura da sutura e consequentemente diminuir o tempo de contenção dos aparelhos disjuntores. A necessidade de determinar os efeitos bioestimulatórios do laser de baixa potência na regeneração óssea fez com que os pesquisadores buscassem elucidar e relacionar a função osteoblástica com a laserterapia. Foi observado em estudos in vitro que a síntese e a deposição óssea da matriz extracelular é fortemente estimulada quando associada a irradiação do laser (Dörtbudak et al., 2000; Pretel et al., 2007; De Souza Merli et al., 2012; Guzzardella et al., 2002; Crisan et al., 2015). Focados nos benefícios do laser na regeneração óssea da sutura palatina, os autores Saito e Shimizu, em 1997, obtiveram bons resultados com a utilização do laser de baixa potência após a disjunção palatina em 
camundongos. Os autores sugeriram que a ação fotobiomoduladora do laser possa trazer benefícios terapêuticos, encurtando o período de contenção do procedimento ortodôntico devido à aceleração da regeneração óssea.

Recentemente, Amini et al. (2015) e Aras et al. (2015) avaliaram o efeito da irradiação com o laser sobre a cicatrização de sutura palatina após a expansão da sutura palatina em camundongos. Os autores encontraram que o laser foi capaz de aumentar a taxa de osteogênese na sutura palatina, acelerando a regeneração óssea após a disjunção. Outros autores também avaliaram in vitro os efeitos da laserterapia em procedimentos de expansão rápida da maxila encontrando resultados favoráveis sobre sua influência na regeneração óssea (Da Silva et al., 2012; Santiago et al., 2012).

Em 2012, Cepera et al. avaliaram os efeitos da laserterapia sobre a regeneração óssea em procedimentos de expansão de 27 crianças com idade média de 10,2 anos. Os autores utilizaram Laser de Diodo $(780 \mathrm{~nm}, 40 \mathrm{~mW})$ em 10 pontos não paralelos, por um tempo de 10 segundos em cada ponto e encontraram que esta aplicação influenciou no processo de regeneração óssea da sutura, acelerando a cicatrização da sutura palatina e diminuindo o tempo de contenção do aparelho.

O aparelho de laser normalmente utilizado para estimular a formação óssea, inclusive nos estudos que avaliaram essa estimulação na sutura palatina mediana, é o Laser de Diodo, variando-se os parâmetros principalmente relacionados ao comprimento de onda, potência e tempo de irradiação. A maioria dos estudos utilizam comprimentos de onda que variam entre 780-830 nm (Saito e Shimizu, 1997; Dörtbudak et al., 2000; Pretel et al., 2007; Cepera et al., 2012; Da Silva et al., 2012; De Souza Merli et al., 2012; Santiago et al., 2012, Amini et al., 2015; Aras et al. 2015). Jawad et al. (2013), analisou o efeito da irradiação com Laser de Diodo em diferentes potências e tempos de exposição no comprimento de onda de $940 \mathrm{~nm}$ sobre os estágios de proliferação e diferenciação dos osteoblastos. Os autores encontraram que o grupo onde foi utilizada a potência de $300 \mathrm{~mW}$ apresentou a maior taxa de proliferação celular, embora os grupos com potências de 100 e 200 mW apresentaram taxas significativamente mais elevadas de diferenciação celular, sendo que os melhores resultados foram apresentados para o grupo de $200 \mathrm{~mW}$ com tempo de exposição de 6 minutos, deixando claro a importância de trabalhos que avaliem a ação dos diferentes parâmetros de um mesmo equipamento. Existem poucos estudos utilizando o laser de diodo com comprimento de onda de $980 \mathrm{~nm}$ na área da Odontologia (Azma e Safavi, 2013; Luers et al., 2014), no entanto não existe nenhum estudo que se proponha a avaliar o efeito terapêutico na sensação dolorosa e fotobiomodulação óssea desse comprimento de onda em pacientes submetidos a expansão rápida da maxila. 
A diminuição do tempo necessário para que ocorra o reparo ósseo após a expansão rápida da maxila, e a diminuição dos incômodos causados durante este processo são vantagens que podem levar a maior adesão e aceitação do tratamento pelo paciente, uma vez que a grande maioria deles são crianças e devido à pouca idade possuem maior dificuldade em entender e colaborar durante os procedimentos (Saito e Shimizu, 1997; Cepera et al., 2012; Da Silva et al., 2012).

Tendo em vista os aspectos apresentados, justifica-se a pesquisa pela necessidade de mais estudos na área, com a finalidade de avaliar os benefícios do laser com relação a diminuição do incômodo pós-ativação e do tempo de contenção e estímulo à formação óssea, em procedimentos de expansão rápida da maxila em humanos. Paralelamente, será de grande utilidade avaliar o espaço nos arcos dentários superior e inferior após ERM. 
2. Prapasiçãa 


\section{PROPOSIÇÃo}

Os objetivos deste estudo foram:

1. Avaliar a ação do laser de baixa potência na formação óssea da sutura palatina mediana em pacientes submetidos a ERM.

2. Comparar a sensação dolorosa durante o procedimento de ERM entre pacientes submetidos à irradiação com laser de baixa potência e pacientes submetidos à irradiação com efeito placebo.

3. Avaliar o espaço nos arcos dentários superior e inferior antes e após o procedimento de ERM. 
3. Materiale Métados 


\section{Material e Métodos}

Previamente a sua realização, esta pesquisa foi submetida e aprovada pelo Comitê de Ética em Pesquisa para seres humanos da Faculdade de Odontologia de Ribeirão Preto da Universidade de São Paulo com o protocolo CAAE 50417215.4.0000.5419 (Anexo 1, página 95).

\subsection{Seleção dos pacientes}

Inicialmente foram selecionados 40 participantes para esta pesquisa de acordo com cálculo amostral realizado pelo programa SAS "Statistical Analysis System" 9.3 (SAS, Cary, NC, USA), que considerou um poder de teste de $80 \%$ e alfa de 0.05 e revelou a necessidade de 20 indivíduos em cada grupo, levando-se em consideração as possíveis perdas. Desta forma, os 40 participantes da pesquisa foram aleatoriamente alocados em dois grupos, sendo um grupo experimental e um grupo controle $(n=20)$.

Os participantes da pesquisa foram de ambos os sexos, com idades entre 6 a 12 anos, com atresia esquelética da maxila caracterizada por distância intermolar menor ou igual a $31 \mathrm{~mm}$ (medida entre os primeiros molares permanentes superiores, por palatino na região cervical adjacente ao sulco) (Figura 1A) (McNamara, 2000), ou mordida cruzada lingual posterior esquelética maior ou igual a $4 \mathrm{~mm}$, medida da ponta das cúspides vestibulares dos primeiros molares permanentes superiores até a superfície vestibular dos primeiros molares permanentes inferiores (Figura 1B). Os pacientes que apresentavam tais características e se encaixassem nos critérios de inclusão e exclusão propostos na Tabela 1 (página 45) foram convidados a participar da pesquisa.
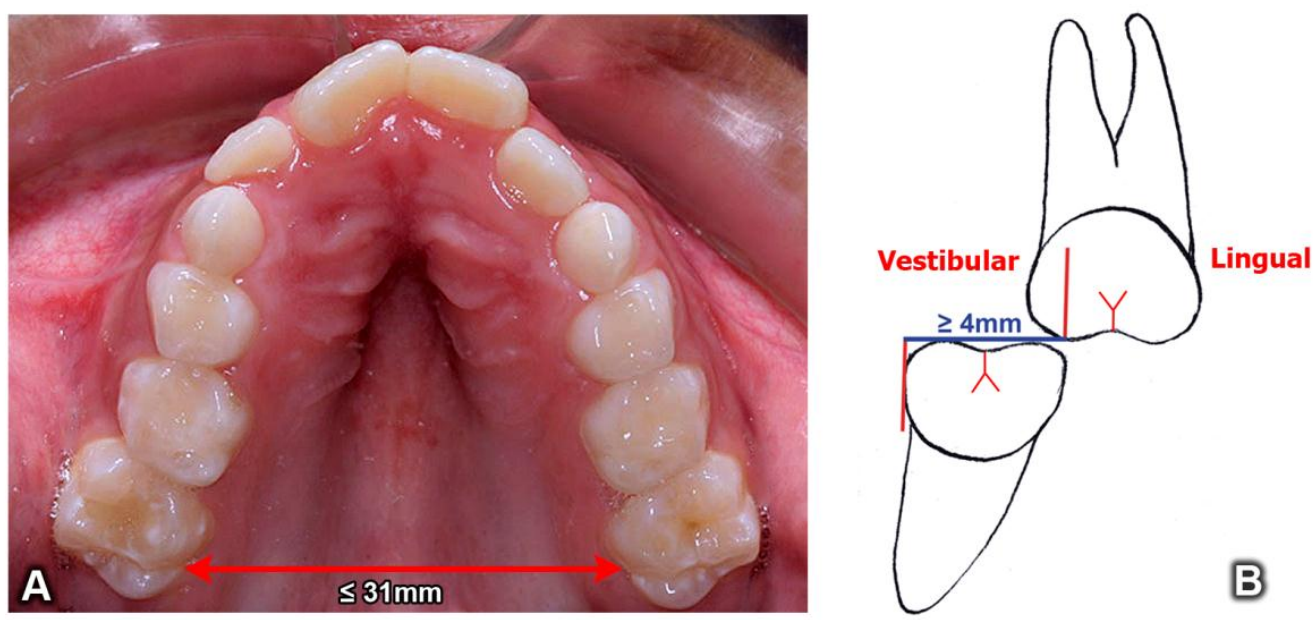

Figura 1: A - Atresia esquelética da maxila comprovada pelo estreitamento do arco e com distância intermolar $\leq 31 \mathrm{~mm}$. B - Desenho esquemático de mordida cruzada posterior lingual $\geq 4 \mathrm{~mm}$. 
Tabela 1: Critérios de inclusão e exclusão da amostra.

\begin{tabular}{cc} 
Critérios de Inclusão & Critérios de Exclusão \\
- Idade: 6 a 12 anos & - Pigmentação melânica na região do palato \\
- Sexo: feminino ou masculino & - Pacientes com alterações sistêmicas \\
- Dentição Mista & - Pacientes com necessidades especiais \\
- Atresia esquelética maxilar ou mordida & - Mal formações dentárias \\
cruzada posterior $\geq 4$ mm uni ou bilateral & - Alto risco à cárie \\
- Distância intermolar $\leq 31 \mathrm{~mm}$ & - Alta atividade de cárie \\
\hline
\end{tabular}

Os responsáveis legais pelos participantes da pesquisa foram esclarecidos sobre a metodologia utilizada na pesquisa e seus objetivos. Após concordarem com a participação das crianças no estudo, eles assinaram o TCLE (Termo de Consentimento Livre e Esclarecido - Anexo 2, página 99) e os participantes da pesquisa o Termo de Assentimento (Anexo 3, página 101).

\subsection{Documentação ortodôntica, análise inicial e planejamento dos casos}

Foram solicitadas documentações ortodônticas aos participantes da pesquisa incluindo radiografia oclusal da maxila, radiografia panorâmica, teleradiografia lateral, modelos de estudo e fotografias extrabucais (frente, frente sorrindo e perfil), intrabucais (lateral direita, lateral esquerda, frontal, oclusal superior e oclusal inferior). Os pacientes foram submetidos à exame clínico, anamnese e todas as avaliações necessárias para diagnóstico e planejamento do caso. A avaliação e planejamento dos casos seguiram o protocolo utilizado na clínica de graduação da disciplina de Ortodontia da FORP - USP.

A discrepância óssea, obtida pela Análise da Dentição Mista (ADM) nos modelos de gesso, foi realizada seguindo o método proposto por Moyers (1951) para posterior comparação com a documentação final que foi solicitada ao final do tratamento.

\subsection{Procedimento de ERM}

O plano de tratamento inicial para todos os pacientes consistiu na utilização do aparelho Hyrax (Figura 2, página 46). 


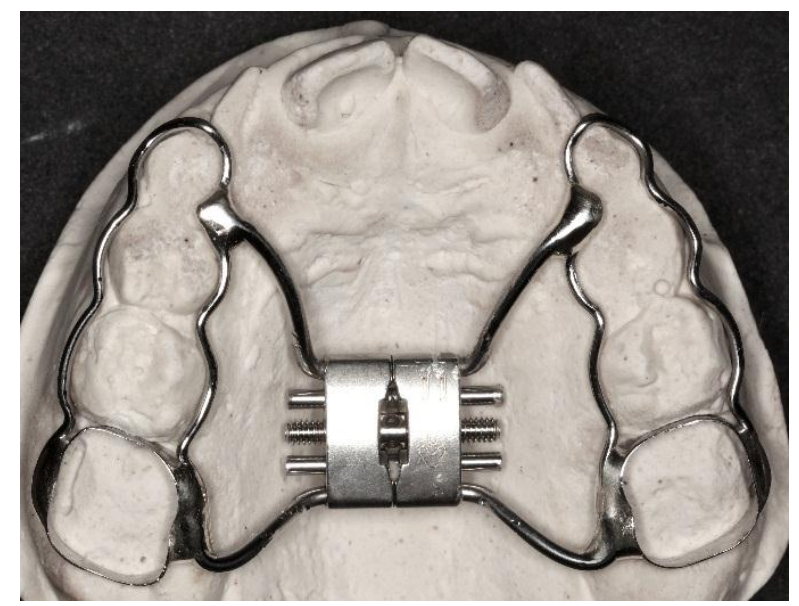

Figura 2: Aparelho Hyrax.

Os passos clínicos para confecção e cimentação do aparelho foram:

Inicialmente foi colocado elástico de separação entre os segundos molares decíduos e os primeiros molares permanentes superiores. Após uma semana foi realizado o procedimento de bandagem dos primeiros molares permanentes, moldagem, transferência das bandas e vazamento do gesso com as bandas posicionadas corretamente. Os elásticos de separação foram novamente colocados entre os segundos molares decíduos e os primeiros molares permanentes superiores.

A confecção do aparelho foi realizada com fio ortodôntico 1,0mm que circundou os molares e caninos decíduos e posteriormente foi soldado às bandas dos molares permanentes superiores. O parafuso expansor foi posicionado centralmente no palato e unido por meio de seu fio às bandas e à estrutura metálica que circundou os molares e caninos decíduos (Figura 2).

$\mathrm{Na}$ semana seguinte à bandagem e moldagem, foi cimentado o aparelho nos primeiros molares permanentes e colado com resina por vestibular nos caninos. 0 passo a passo da confecção do aparelho incluindo as fases clínicas e laboratoriais estão descritas na Figura 3 (página 47). 

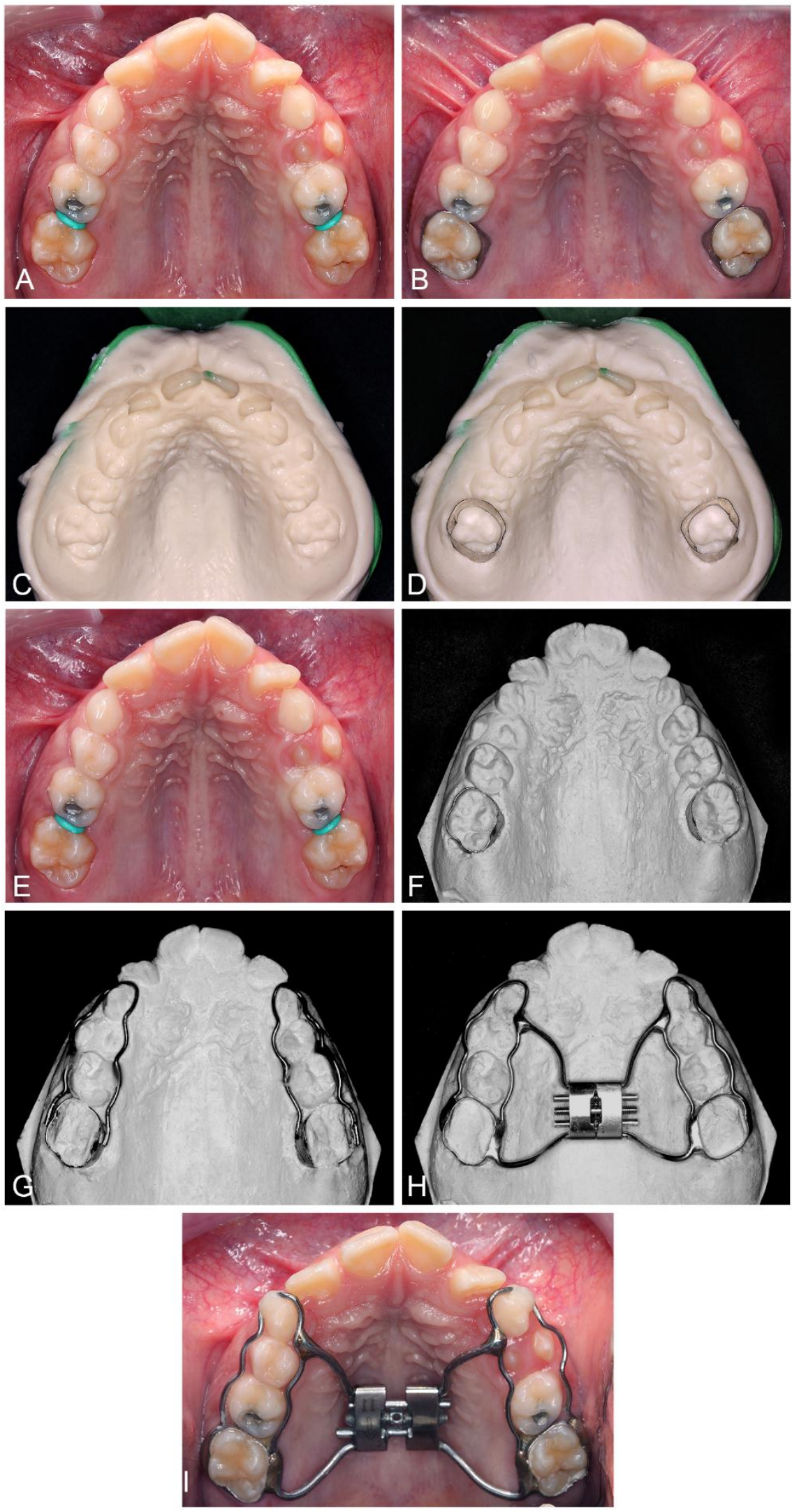

Figura 3: A - Elástico de separação entre os segundos molares decíduos e os primeiros molares permanentes. B - Bandagem dos primeiros molares permanentes. C - Moldagem. D - Transferência de bandas do paciente para a moldagem. E - Novo elástico de separação entre os segundos molares decíduos e os primeiros molares permanentes. F - Modelo de trabalho. G - Início da confecção do aparelho. H - Aparelho confeccionado sobre o modelo de trabalho. I - Aparelho cimentado e colado uma semana após a bandagem e moldagem. 
Todos os procedimento clínicos foram realizados pelos mesmo operador (F.L.R.) na clínica 1 da Faculdade de Odontologia de Ribeirão Preto. As fases laboratoriais também foram realizadas por um único profissional (C.E.T.B.) no laboratório de apoio clinico da disciplina de Ortodontia. O acompanhamento dos pacientes após a cimentação do aparelho foi realizado pela operadora (D.S.M.).

A fase ativa iniciou-se no dia da instalação do aparelho, seguindo o protocolo descrito por Haas, em 1961. Foram realizadas 4 ativações iniciais de $1 / 4$ de volta, com intervalos de 15 minutos entre cada ativação. A profissional (D.S.M.) realizou 2 ativações e o responsável outras 2 ativações para treinamento, calibração e verificação de que realizaria as ativações de forma correta. Neste momento o paciente e seu responsável receberam orientações quanto à ativação e higienização do aparelho, sendo entregue um folheto (Anexo 4, página 103) com todas as informações e telefone de contato da profissional (D.S.M.) para eventuais problemas ou dúvidas. A partir do $2^{\circ}$ dia foram realizadas pelo responsável 2 ativações diárias, sendo $1 / 4$ de volta pela manhã e outro $1 / 4$ de volta à noite com intervalo de 12 horas entre elas. Foram realizados controles semanais e a ativação do aparelho foi interrompida quando houve sobrecorreção da mordida cruzada posterior ou da atresia maxilar, com as vertentes vestibulares das cúspides palatinas dos dentes posteriores superiores ocluindo nas vertentes linguais das cúspides vestibulares dos dentes posteriores inferiores (Figura 4A, B, C e D). Após a sobrecorreção, que ocorreu entre 15 a 21 dias após o início da ativação, o parafuso foi imobilizado com resina acrílica cobrindo toda sua extensão (Figura 4B). O próprio aparelho permaneceu na boca como contenção por um período de 6 meses.
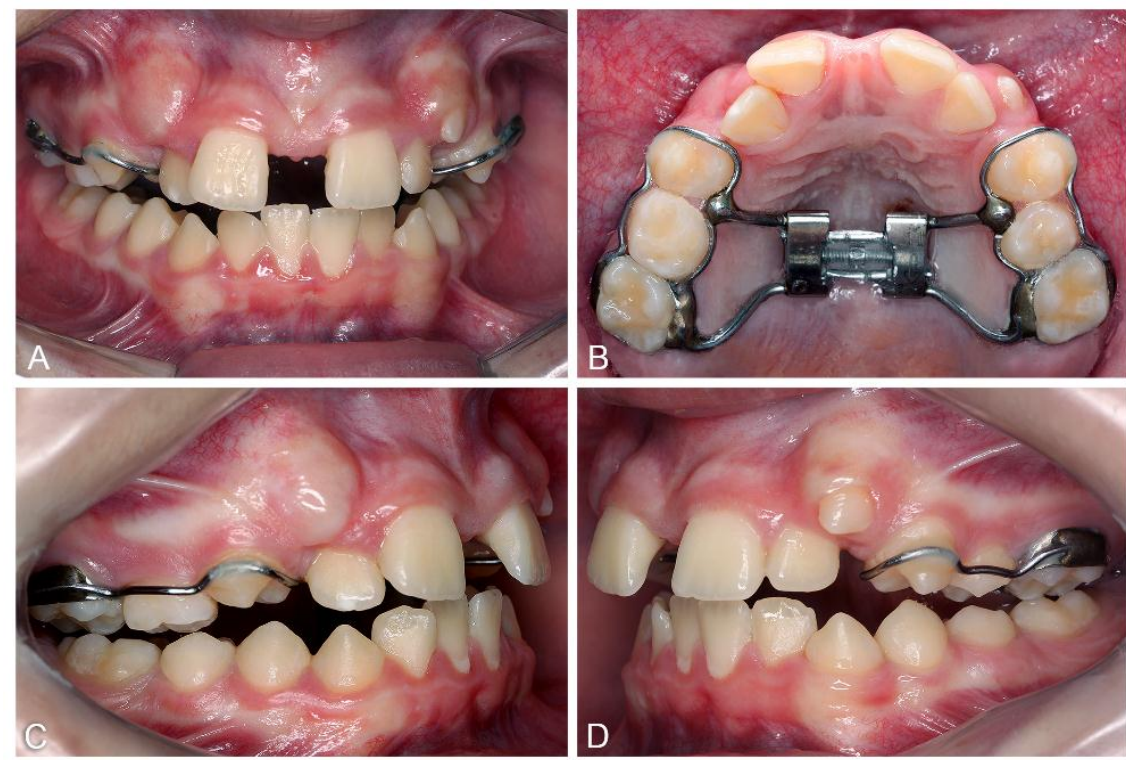

Figura. 4: Final do procedimento de disjunção evidenciando sobrecorreção. A - Vista frontal, abertura de diastema; B - Vista oclusal, parafuso expansor imobilizado com resina acrílica; C - Vista lateral direita; D Vista lateral esquerda. 


\subsection{Irradiação do Laser}

A irradiação do laser de diodo (Einstein DL da Empresa DC International, Carmel, CA, USA) (Figura 5) com 980nm, 0,3 W, CW (corrente contínua) e fibra óptica com diâmetro de $0,4 \mathrm{~mm}$ foi realizada no momento da instalação do aparelho logo após às 4 ativações iniciais (L1) em 6 pontos distribuídos bilateralmente, paralelos e a uma distância de cerca de $0,5 \mathrm{~cm}$ da sutura palatina mediana, com duração de 10 segundos em cada ponto. A distância entre a papila incisiva e a porção anterior do parafuso foi mensurada e dividida em três partes iguais para determinação dos pontos (Figura 6). A localização dos pontos foi definida com base no fato de que a abertura da sutura durante os procedimentos de disjunção ocorre em "V", sendo na região anterior e inferior da maxila onde verifica-se maior abertura.

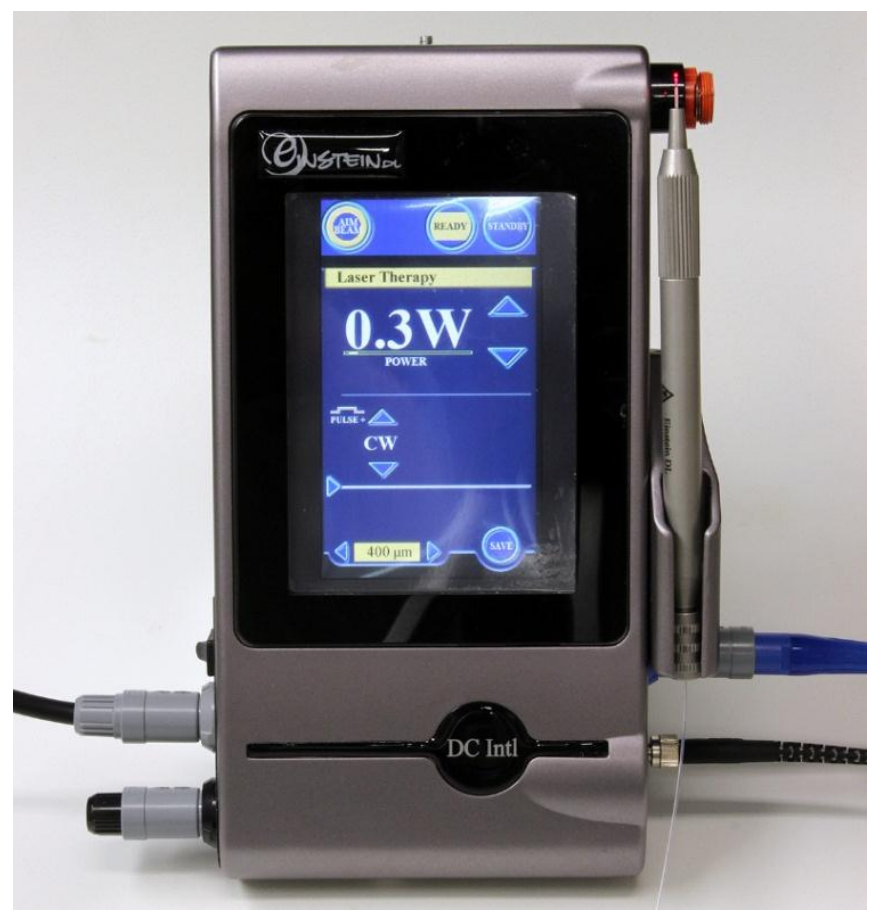

Figura 5: Laser de diodo.

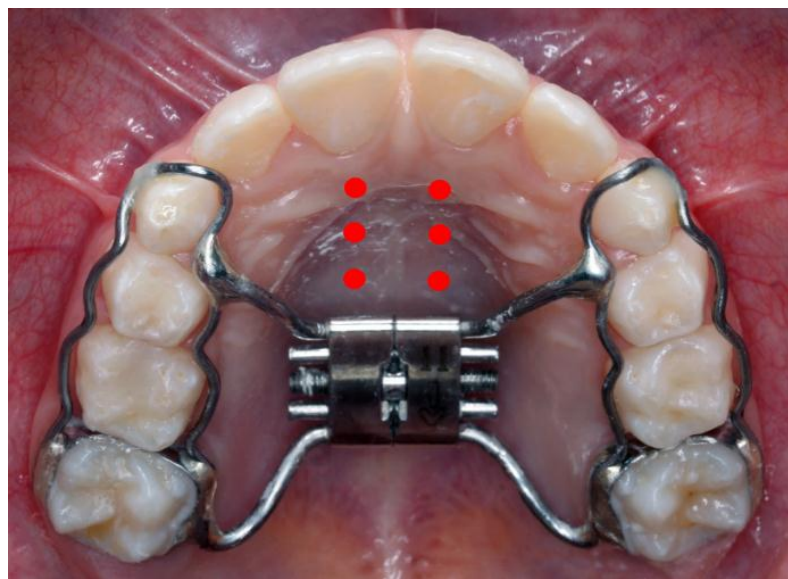

Figura 6: Pontos de irradiação do laser próximos a sutura palatina mediana. 
Durante a fase ativa do tratamento foram realizadas mais 3 aplicações: 5, 10 e 15 dias de tratamento (L2, L3 e L4) e após a imobilização do parafuso, 1 vez por semana durante 8 semanas (L5, L6, L7, L8, L9, L10, L11, L12) sendo a L5 logo após a imobilização. Os pacientes do grupo controle receberam simulação da irradiação do laser com o aparelho desligado (modo Standby) para caracterizar o efeito placebo.

As aplicações de laser foram realizadas pela profissional D.S.M que foi previamente treinada e calibrada por profissional especialista na área (R.G.P.D.).

\subsection{Análise Radiográfica}

Para avaliação da densidade óssea, foram realizadas radiografias oclusais digitais com auxílio de posicionador radiográfico (Prisma, Pirituba, SP, Brasil) e penetrômetro para padronização e posterior comparação dos tons de cinza encontrados nas radiografias. Todas as radiografias foram realizadas com o paciente posicionado sentado em cadeira odontológica, de maneira que o plano oclusal estivesse paralelo ao solo. Foi utilizado o sistema digital Vista Scan (Dürr Dental, Bietigheim-Bissingen, Baden-Württemberg, Alemanha) e o mesmo sensor radiográfico digital (placa de fósforo) foi utilizado para todos os participantes. O sensor foi envolvido em plástico descartável que foi trocado a cada tomada radiográfica, seguindo os princípios de biossegurança. Os parâmetros de tempo de exposição e voltagem giraram em torno de 0,25 segundos e 70kV sendo utilizado em todos os exames o mesmo aparelho radiográfico (Dabi Atlante Seletronic, Ribeirão Preto, SP, Brasil). As imagens foram exportadas no formato JPEG e arquivadas no computador para posterior análise. Para o procedimento radiográfico, os pacientes estavam devidamente protegidos com avental de chumbo e protetor de tireóide (Figura 7A e B, página 51). 

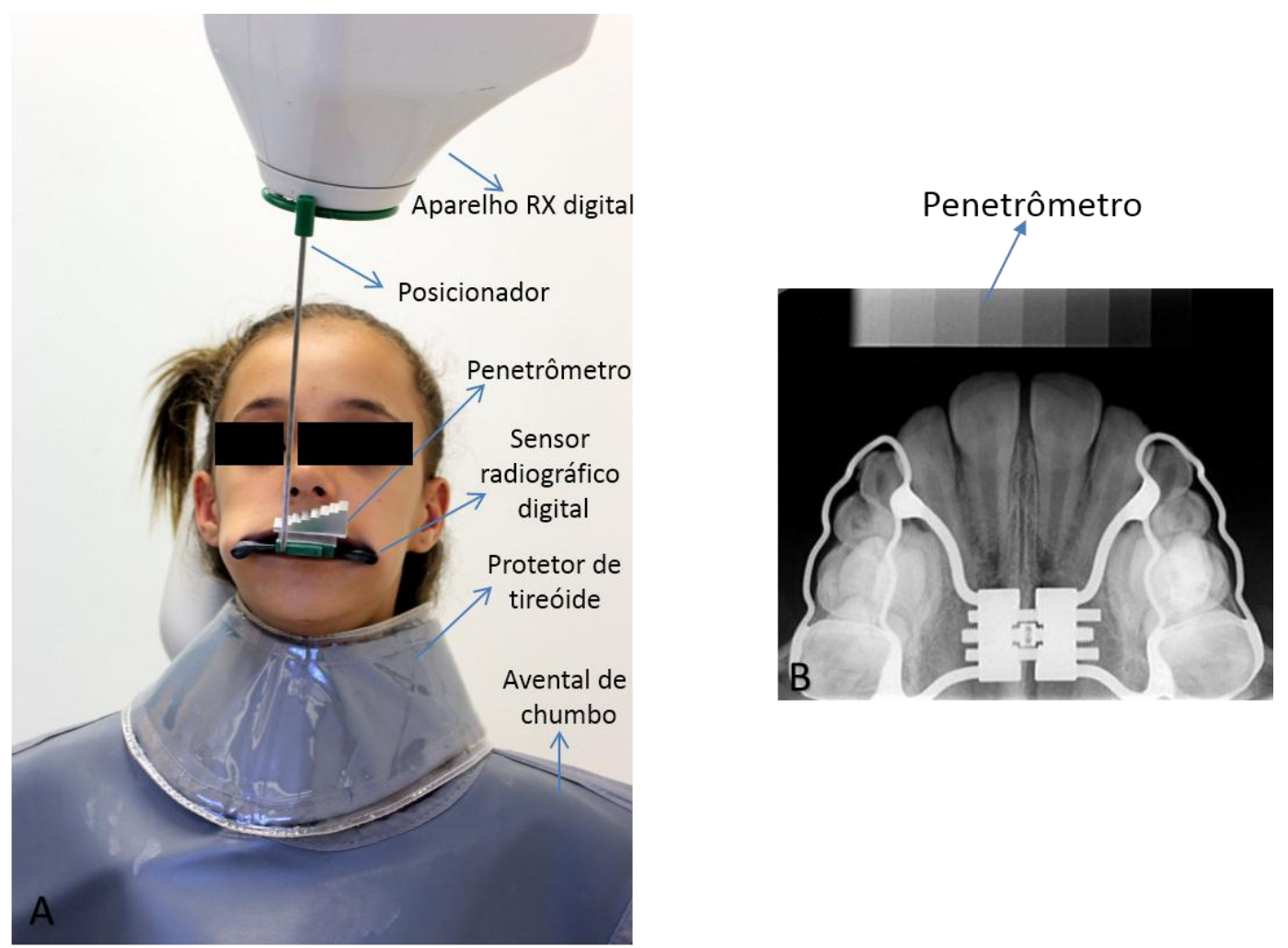

Figura 7: A - Ilustração da tomada radiográfica oclusal. B - Radiografia oclusal digital padronizada.

Todas as tomadas radiográficas foram realizadas pela mesma operadora (D.S.M) que foi treinada e calibrada pelo profissional responsável da área (T.J.R.).

Além da radiografia oclusal para diagnóstico incluída na documentação ortodôntica inicial, foram realizadas outras 5 radiografias: no momento da imobilização do parafuso expansor (R1), 1 mês (R2), 2 meses (R3), 3 meses (R4) e 6 meses (R5). As radiografias foram avaliadas por meio do software Image J 1.50 b (National Institutes Health, Betheseda, MD, USA) que mede o valor de pixel em pontos previamente selecionados. Para padronização destes pontos, foi traçada em cada radiografia uma linha horizontal próxima à borda anterior do parafuso expansor e após foi delimitado uma ROI (Region of Interest Região de Interesse) o mais próximo possível deste parafuso, na área radiolúcida entre as hemi-maxilas obtida após a abertura da sutura (R1), sem incluir suas extremidades (ROI 1). O programa Image $\mathrm{J}$ fornece o valor de pixel que corresponde ao tom de cinza na imagem variando-se de 0 (preto) a 255 (branco). Para comparações entre os diferentes tempos, levando-se em consideração eventuais variações energéticas entre as diferentes tomadas radiográficas, foi realizado ajuste do valor de pixel através da mensuração deste valor em objeto com material, espessura e densidade constantes. Para tal, foi selecionada também uma ROI no centro do quarto degrau do penetrômetro medindo $120 \times 120$ pixels (ROI 2), para mensuração do valor de pixel desta área. A ROI 1, delimitada na área da sutura, foi 
então comparada por meio de regra de três com a ROI 2 delimitada no penetrômetro, obtendo assim o valor de pixel ajustado para aquela imagem (Figura 8). Nas demais radiografias ( $R 2$, $R 3$, R4 e R5), foram realizados os mesmos procedimentos para delimitação da ROI e obtenção do valor de pixel. As áreas delimitadas nas demais radiografias continham as mesmas dimensões para um mesmo paciente.

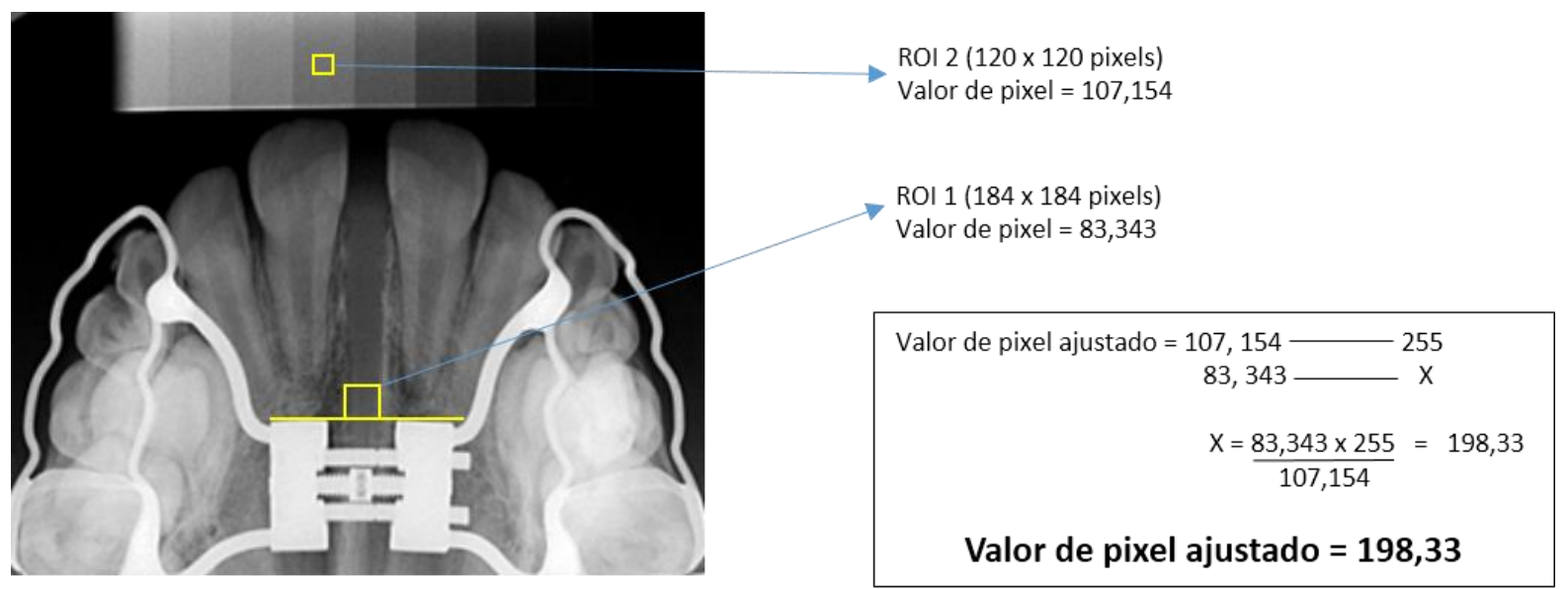

Figura 8: Regiões de interesse (ROIs) delimitadas no centro da sutura palatina após abertura (ROI 1) e no degrau central do penetrômetro (ROI 2) para comparação e obtenção do valor de pixel ajustado.

As radiografias digitais foram escolhidas para este trabalho por apresentarem menor possibilidade de repetição em consequência de erros no processamento, melhor qualidade das imagens, menor tempo de exposição, além de diminuir uma etapa na análise das imagens que seria a digitalização das mesmas (Hayakawa et al., 1997; Yoshiura et al., 1999a, Yoshiura et al., 1999b; Anisse e Geibel, 2014).

A examinadora (D.S.M.) foi treinada e calibrada previamente a realização das análises radiográficas no programa Image J. Para a calibração, foram analisadas 34 radiografias pelo calibrador (C.O.S) e essas mesmas radiografias foram reanalisadas posteriormente pela examinadora sendo que a correlação intraclasse foi de 0,971 com intervalo de confiança de $95 \%(0,942-0,985)$. Foi avaliada também a reprodutibilidade dos dados apresentados pela examinadora que reavaliou outras 34 radiografias aleatorizadas pelo calibrador, 15 dias após a primeira avaliação, sendo encontrada uma correlação de 0,988 com intervalo de confiança de 0,95\% $(0,977-0,994)$.

Ao longo da pesquisa, foram perdidos alguns participantes devido a falta de assiduidade às consultas e algumas radiografias foram descartadas levando-se em consideração a qualidade da imagem. Ao final, o grupo experimental apresentava-se com 18 participantes $(n=18)$ e o grupo o controle com 16 participantes $(n=16)$ com um total de 164 radiografias analisadas nesta fase. 
A Figura 9 ilustra quando foram realizadas as aplicações do laser e as tomadas radiográficas oclusais.

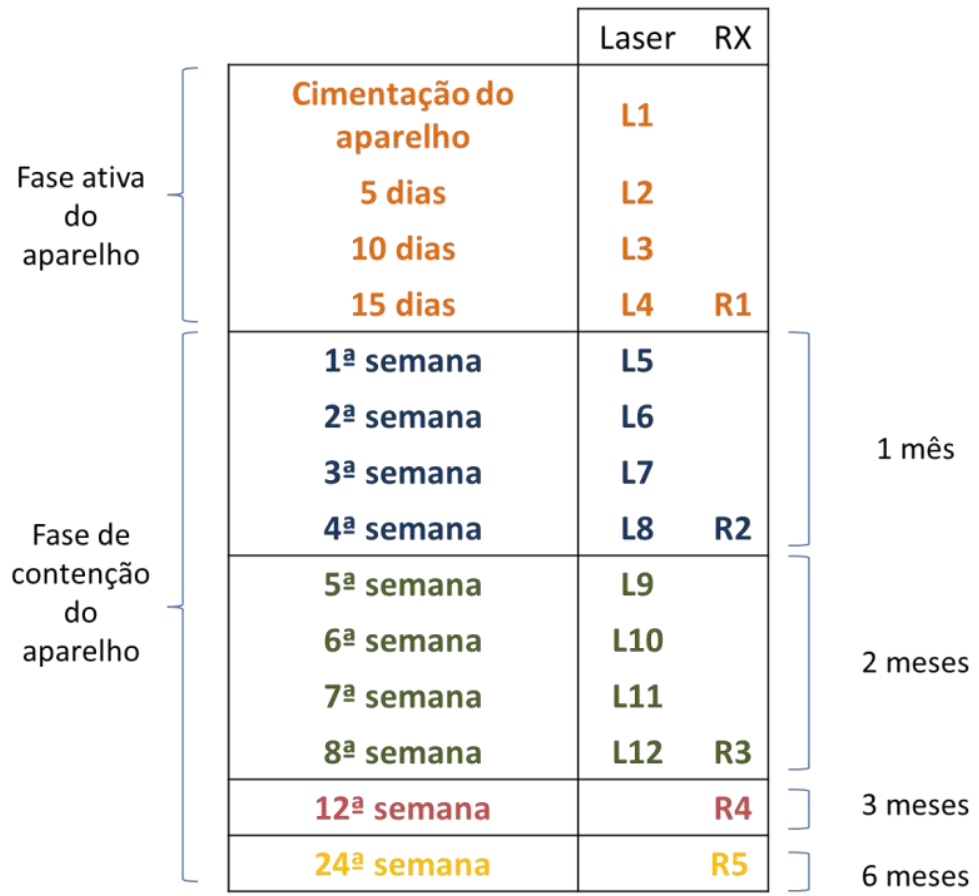

Figura 9: Cronograma das aplicações do laser (L) e realização das tomadas radiográficas oclusais (R).

\subsection{Avaliação da sensação dolorosa}

Durante a fase de ativação do aparelho, os pacientes foram orientados a anotarem diariamente o nível de dor sentido após cada ativação, em uma escala visual analógica baseada na "Wong-Baker Faces Pain Scale" (FPS) (Garra et al., 2013; Baldini et al., 2015) (Figura 10). Posteriormente foi comparado entre os grupos da pesquisa (controle e experimental) se o laser foi capaz de diminuir a sensação dolorosa ou o incômodo durante a fase ativa do tratamento.

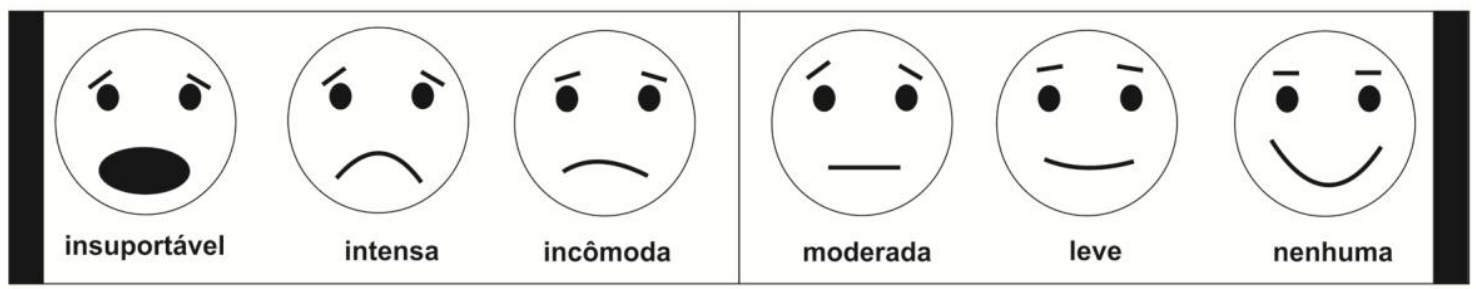

Figura 10: Escala visual analógica de dor.

\subsection{Análise da Dentição Mista (ADM)}

Ao final do período de contenção, após a remoção do aparelho disjuntor, novas documentações ortodônticas foram solicitadas aos pacientes para avaliação do tratamento 
executado e planejamento das próximas etapas. Uma nova ADM seguindo o método proposto por Moyers (1991) foi realizada nos modelos finais, a fim de comparar e avaliar as alterações ocorridas após a disjunção no perímetro dos arcos dentários superior e inferior.

Dos 34 indivíduos que participaram da primeira etapa do estudo, 3 não realizaram a documentação ortodôntica final, portanto nesta fase onde foi avaliado o ganho ou não de espaço por meio da ADM foram analisados somente 31 indivíduos. A reprodutibilidade dos dados apresentados pela examinadora (K.O.C.H.) foi avaliada, sendo encontrada uma correlação de 0,997 com intervalo de confiança de 95\% (0,995 - 0,998).

O método utilizado para ADM consistiu:

Inicialmente foi realizada a correção das linhas médias (superior e inferior) por meio de um transferidor apoiado sobre o modelo de gesso superior com sua linha central $\left(90^{\circ}\right)$ coincidente com a rafe palatina mediana e com sua base paralela a região posterior do modelo de gesso. A linha de $90^{\circ}$ do transferidor foi transferida para a região dos incisivos superiores onde fez-se a marcação no modelo. Com os modelos ocluídos foi realizada a transferência da linha média corrigida no arco superior para o arco inferior (Figura 15 A, B e C, página 58).

\subsubsection{Procedimento no arco inferior}

1. Mensuração do maior diâmetro mesiodistal de cada um dos quatro incisivos inferiores próximo ao bordo incisal (área de maior diâmetro) com um paquímetro digital de pontas finas (Figura 15 D, E, F e G, página 58). Na sequência, os valores obtidos foram registrados na ficha da ADM (Figura 11).

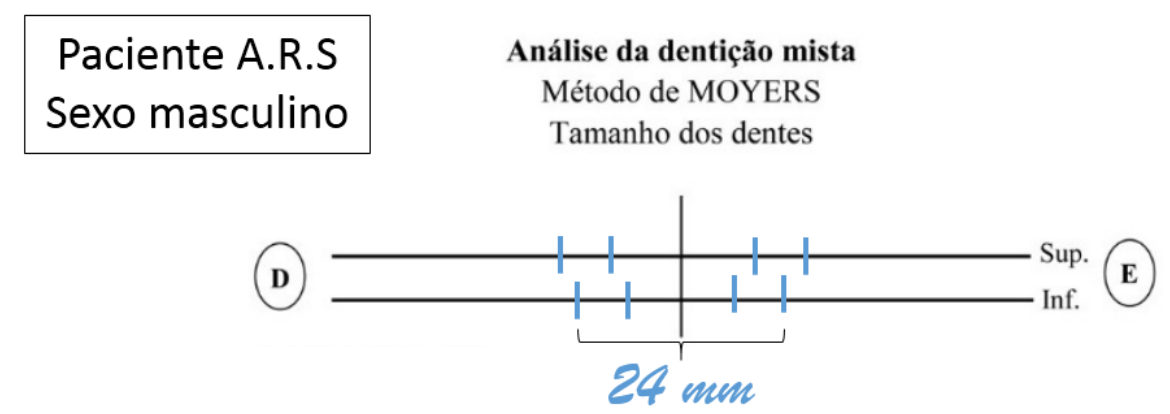

Figura 11: Registro do diâmetro mesiodistal dos incisivos na ficha da ADM.

2. Determinação da quantidade de espaço necessária para o alinhamento dos incisivos. Primeiramente, regulando a ponta do paquímetro em um valor igual à soma dos diâmetros MD dos incisivos central e lateral direito, posicionou-se uma ponta do instrumento na linha média da crista alveolar entre os incisivos centrais e a outra ponta ao longo da linha do arco dentário do lado direito e marcou-se no modelo. $\mathrm{O}$ processo foi repetido para o lado esquerdo (Figura $15 \mathrm{H}$, página 58). 
3. A quantidade de espaço disponível após o alinhamento dos incisivos foi mensurada medindo-se a distância do ponto marcado na linha do arco no modelo de estudo (passo 2) até a superfície mesial do primeiro molar permanente em ambos os hemiarcos (Figura 15 I e J, página 58).

4. Previsão dos diâmetros mesio-distais combinados de caninos e pré-molares inferiores que estão intra-ósseos por meio do quadro de probabilidades de Moyers com nível de predição de 75\%. Com a soma dos diâmetros mésio-distais (M-D) dos incisivos inferiores, localizou-se na tabela (Figura 12) o valor estimado para a somatória dos diâmetros de caninos e pré-molares por hemiarco, de acordo com o sexo do paciente.

Paciente A.R.S

Sexo masculino
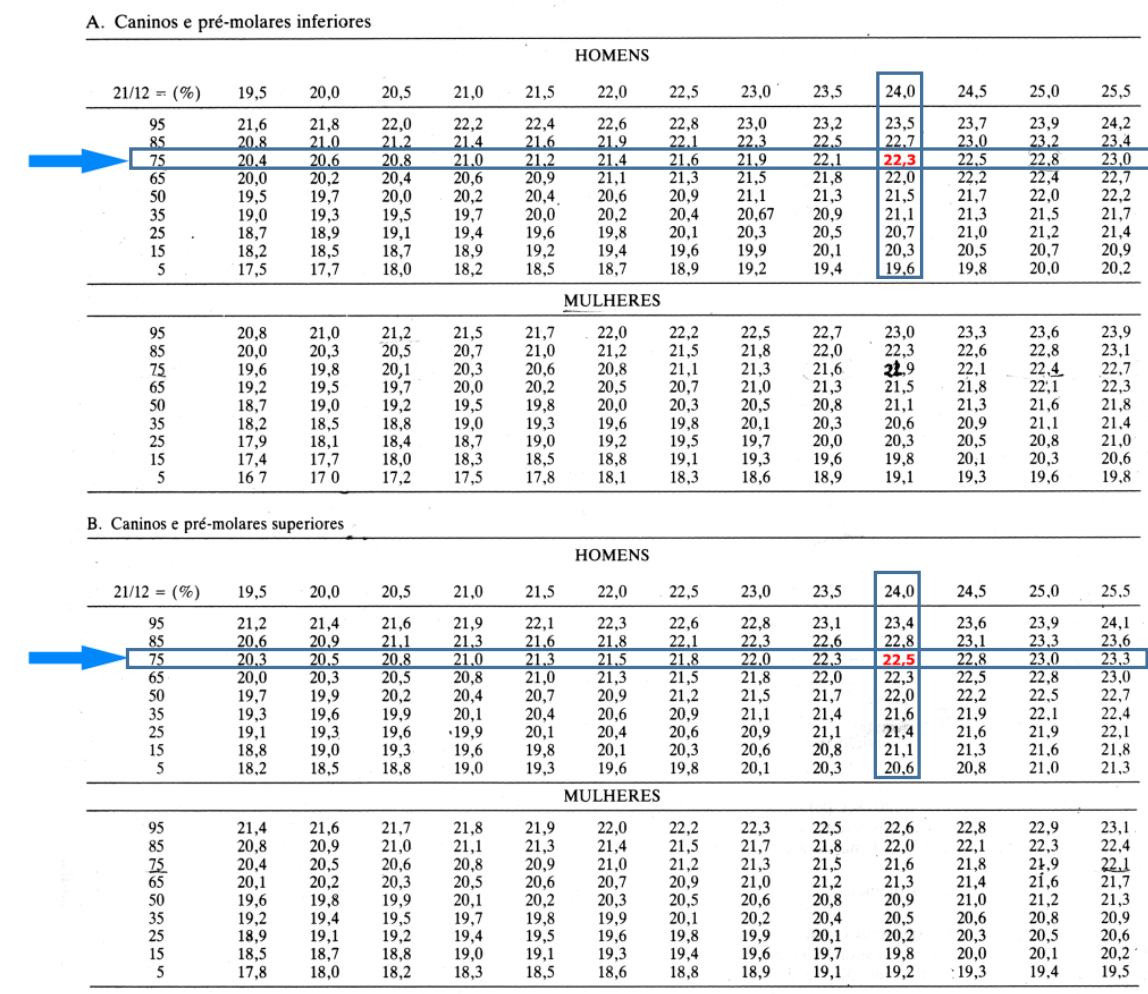

Figura 12: Previsão do tamanho dos diâmetros combinados dos caninos e pré-molares por hemiarco.

5. Acrescentou-se ao tamanho da previsão de caninos e pré-molares o espaço necessário para obtenção da relação molar em classe I (ajuste molar) quando foi necessário.

6. Subtração do valor da quantidade de espaço disponível após alinhamento dos incisivos (passo 3) com a previsão do tamanho dos diâmetros de caninos e prémolares inclusos mais o valor do ajuste molar (passos 4 e 5). A diferença foi computada para os lados direito e esquerdo (Figura 13, página 56). 


\begin{tabular}{|l|c|c|c|c|}
\hline \multirow{2}{*}{ Paciente A.R.S } \\
\cline { 2 - 5 } Sexo masculino & \multicolumn{2}{|c|}{ Inferior } & \multicolumn{2}{c|}{ Superior } \\
\cline { 2 - 5 } \multicolumn{1}{l|}{} & Direito & Esquerdo & Direito & Esquerdo \\
\hline Espaço deixado após alinhamento de 2 e 1 & $20.53 \mathrm{~mm}$ & $20.07 \mathrm{~mm}$ & $20.29 \mathrm{~mm}$ & $20.65 \mathrm{~mm}$ \\
\hline Tamanho previsto para 3+4+5 & $22.30 \mathrm{~mm}$ & $22.30 \mathrm{~mm}$ & $22.50 \mathrm{~mm}$ & $22.50 \mathrm{~mm}$ \\
\hline Ajuste molar & & & & - \\
\hline Discrepância de Modelos & $-1.77 \mathrm{~mm}$ & $-2.23 \mathrm{~mm}$ & $-2.21 \mathrm{~mm}$ & $-1.85 \mathrm{~mm}$ \\
\hline
\end{tabular}

Figura 13: Cálculo da discrepância de modelos por hemiarco para os lados direito e esquerdo.

A ficha utilizada na ADM está representada na Figura 14 (página 57).

\subsubsection{Procedimento no superior}

O procedimento para o arco superior foi similar ao do arco inferior, com duas diferenças:

1. Um quadro diferente de probabilidade foi usado para predizer a somatória de caninos e pré-molares superiores (Figura 12, página 55).

2. Os diâmetros dos incisivos inferiores também foram usados para predizer os diâmetros dos caninos e pré-molares superiores intra-ósseos por hemiarco (Figura 13). 


\section{Análise da dentição mista}

Método de MOYERS

Tamanho dos dentes

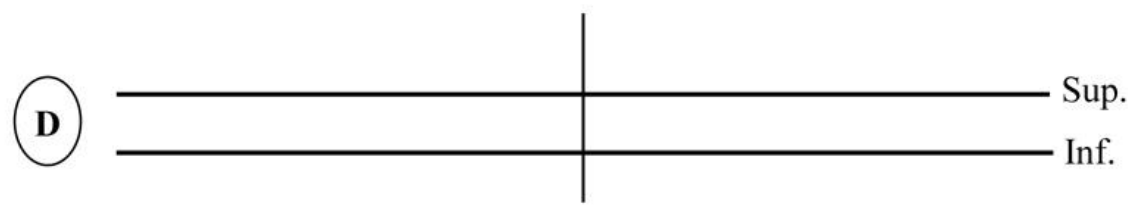

\begin{tabular}{|c|c|c|c|c|c|c|c|c|c|c|c|c|c|}
\hline \multicolumn{14}{|c|}{ HOMENS } \\
\hline $2 \mathrm{~L} / 12 \sim(\%)$ & 19.5 & 20,0 & 20.5 & 21,0 & 21.5 & 22.0 & 22.5 & 23.0 & 23.5 & 24,0 & 24,5 & 25.0 & 25.5 \\
\hline 95 & 21,6 & 21,8 & 22,0 & 22,2 & 22,4 & 22.6 & 22.8 & 23.0 & 23.2 & 23,5 & 23.7 & 23,9 & 24.2 \\
\hline 85 & 20.8 & 21,0 & 21.2 & 21,4 & 21,6 & 21.9 & 22.1 & 22.3 & 22.5 & 22,7 & 23,0 & 23,2 & 23.4 \\
\hline 75 & 20,4 & 20.6 & 20,8 & 21.0 & 21,2 & 21.4 & 21.6 & 21.9 & 22.1 & 22.3 & 22.5 & 22,8 & 23,0 \\
\hline 65 & 20,0 & 20.2 & 20,4 & 20,6 & 20,9 & 21,1 & 21.3 & 21.5 & 21.8 & 22.0 & 22.2 & 22,4 & 22.7 \\
\hline 50 & 19.5 & 19,7 & 20,0 & 20.2 & 20.4 & 20,6 & 20,9 & 21.1 & 21.3 & 21.5 & 21.7 & 22.0 & 22.2 \\
\hline 35 & 19.0 & 19.3 & 19.5 & 19.7 & 20,0 & 20.2 & 20.4 & 20.67 & 20.9 & 21,1 & 21,3 & 21.5 & 21.7 \\
\hline 25 & 18,7 & 18.9 & 19,1 & 19,4 & 19.6 & 19.8 & 20.1 & 20.3 & 20.5 & 20.7 & 21,0 & 21,2 & 21.4 \\
\hline 15 & 18,2 & 18,5 & 18,7 & 18,9 & 19,2 & 19.4 & 19,6 & 19.9 & 20.1 & 20.3 & 20.5 & 20.7 & 20,9 \\
\hline 5 & 17.5 & 17.7 & 18,0 & 18.2 & 18.5 & 18.7 & 18.9 & 19,2 & 19.4 & 19.6 & 19,8 & 20,0 & 20.2 \\
\hline \multicolumn{14}{|c|}{ MULHERES } \\
\hline 95 & 20.8 & 21.0 & 21.2 & 21.5 & 21,7 & 22,0 & 22.2 & 22.5 & 22,7 & 23,0 & 23,3 & 23.6 & 23,9 \\
\hline$\times 5$ & 20.0 & 20,3 & 20.5 & 20.7 & 21,0 & 21.2 & 21.5 & 21.8 & 22,0 & 22,3 & 22,6 & 22,8 & 23.1 \\
\hline 75 & $\begin{array}{l}20,0 \\
19.6\end{array}$ & 19,8 & 20.1 & 20.3 & 20,6 & 20.8 & 21.1 & 21.3 & 21.6 & 32.9 & 22.1 & $22,4$. & 22.7 \\
\hline 65 & $\begin{array}{l}19,0 \\
19.2\end{array}$ & 19,5 & $\begin{array}{l}29.7 \\
19.7\end{array}$ & 20,0 & 20.2 & 20,5 & 20,7 & 21.0 & 21,3 & 21.5 & 21.8 & 22,1 & 22.3 \\
\hline so & 18.7 & 19.0 & 19.2 & 19.5 & 19.8 & 20.0 & 20.3 & 20.5 & 20.8 & 21.1 & 21.3 & 21.6 & $21 . x$ \\
\hline 35 & 18.2 & 18.5 & $\begin{array}{l}19.2 \\
18.8\end{array}$ & 19,0 & 19,3 & $\begin{array}{l}20.0 \\
19.6\end{array}$ & $\begin{array}{l}20.3 \\
19.8\end{array}$ & 20.1 & $\begin{array}{l}20.8 \\
20.3\end{array}$ & $\begin{array}{l}20.1 \\
20.6\end{array}$ & $\begin{array}{l}21.3 \\
20.9\end{array}$ & $\begin{array}{l}21.6 \\
21.6\end{array}$ & 21.4 \\
\hline 25 & $\begin{array}{l}18.2 \\
17.9\end{array}$ & $\begin{array}{l}18.5 \\
18.1\end{array}$ & $\begin{array}{l}8.8 \\
18.4\end{array}$ & $\begin{array}{l}18,0,7 \\
18,7\end{array}$ & $\begin{array}{l}19,3 \\
19,0\end{array}$ & $\begin{array}{l}19.6 \\
19.2\end{array}$ & $\begin{array}{l}19.8 \\
19.5\end{array}$ & $\begin{array}{l}20.1 \\
19.7\end{array}$ & 20.0 & $\begin{array}{l}20,3 \\
20.3\end{array}$ & 20,5 & 20.8 & 21.0 \\
\hline 15 & 17.9 & $\begin{array}{l}18.1 .1 \\
17.7\end{array}$ & $\begin{array}{l}18.4 \\
18,0\end{array}$ & $\begin{array}{l}18,7 \\
18,3\end{array}$ & 18,5 & $\begin{array}{l}18,2 \\
18,8\end{array}$ & $\begin{array}{l}19.5 \\
19.1\end{array}$ & $\begin{array}{l}19,1 \\
19,3\end{array}$ & $\begin{array}{l}200.0 \\
19.6\end{array}$ & $\begin{array}{l}20,3 \\
19,8\end{array}$ & $\begin{array}{l}20,1 \\
20,5\end{array}$ & $\begin{array}{l}20,8 \\
20,8\end{array}$ & 20.6 \\
\hline 5 & 16,7 & 17.0 & 17.2 & 17.5 & 17.8 & 18.1 & 18,3 & 18.6 & 18,9 & 19.1 & 193 & 196 & 19.0 \\
\hline
\end{tabular}

B. Caninos e pré-molares superiores

\begin{tabular}{|c|c|c|c|c|c|c|c|c|c|c|c|c|c|}
\hline $21 / 12=(\%)$ & 19.5 & 20.0 & 20,5 & 21.0 & 21.5 & 22.0 & 22.5 & 23.0 & 23.5 & 24.0 & 24.5 & 25.0 & 25.5 \\
\hline 95 & 21,2 & 21.4 & 21,6 & 21,9 & 22.1 & 22,3 & 22,6 & 22.8 & 23.1 & 23,4 & 23.6 & 23,4 & 24,1 \\
\hline 85 & 20.6 & 20.9 & 21.1 & 21.3 & 21.6 & 21.8 & 22.1 & 22,3 & 22.6 & 22,8 & 23,1 & 23,3 & 23,6 \\
\hline 75 & 20.3 & 20,5 & 20.8 & 21.0 & 21.3 & 21,5 & 21.8 & 22,0 & 22,3 & 22.5 & 22.8 & 23,0 & 23,3 \\
\hline 65 & 20.0 & 20,3 & 20.5 & 20.8 & 21,0 & 21,3 & 21.5 & 21.8 & 22,0 & 22,3 & 22,5 & 22.8 & 23,0 \\
\hline 50 & 19.7 & 19,9 & 20.2 & 20.4 & 20,7 & 20,9 & 21.2 & 21.5 & 21,7 & 22,0 & 22,2 & 22.5 & 22,3 \\
\hline 35 & 19.3 & 19.6 & 19.9 & 20.1 & 20,4 & 20,6 & 20,9 & 21.1 & $\begin{array}{l}21,1 \\
21.4\end{array}$ & $\begin{array}{l}22.0 \\
21.6\end{array}$ & 21.9 & 22,1 & 224 \\
\hline 25 & 19.1 & 19,3 & 19,6 & $\begin{array}{l}.20 .9 \\
.19 .9\end{array}$ & 20,1 & 20,4 & 20.6 & 20.9 & $\begin{array}{l}21.4 \\
21,1\end{array}$ & $\begin{array}{l}21.6 \\
21.4\end{array}$ & 21.6 & 21.9 & 22.1 \\
\hline is & 18.8 & 19,0 & 19.3 & 19.6 & $\begin{array}{l}20,1 \\
19,8\end{array}$ & $\begin{array}{l}20,4 \\
20,1\end{array}$ & $\begin{array}{l}20.6 \\
20.3\end{array}$ & 20.6 & 20,8 & $\begin{array}{l}21.4 \\
21.1\end{array}$ & $\begin{array}{l}21,6 \\
21,3\end{array}$ & 21.6 & 21.8 \\
\hline 5 & 18,2 & 18.5 & 18.8 & 19.0 & 19,3 & 19.6 & 19,8 & 20,1 & 20.3 & 20,6 & 20,8 & 21.0 & 21.3 \\
\hline \multicolumn{14}{|c|}{ MULHERES } \\
\hline
\end{tabular}

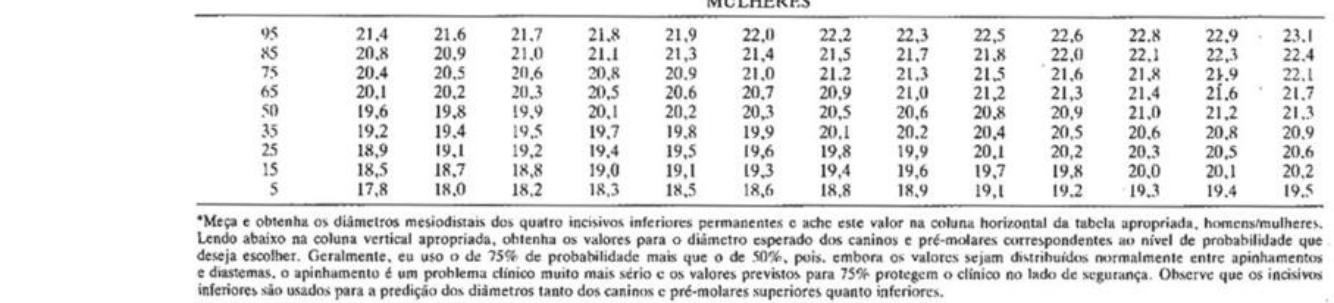

\begin{tabular}{|l|c|c|c|c|}
\cline { 2 - 4 } \multicolumn{1}{c|}{} & \multicolumn{2}{c|}{ Inferior } & \multicolumn{2}{c|}{ Superior } \\
\cline { 2 - 5 } \multicolumn{1}{c|}{} & Direito & Esquerdo & Direito & Esquerdo \\
\hline Espaço deixado após alinhamento de 2 e 1 & & & & \\
\hline Tamanho previsto para 3+4+5 & & & & \\
\hline Ajuste molar & & & & \\
\hline Discrepância de Modelos & & & & \\
\hline
\end{tabular}

Figura 14. Ficha de Análise da Dentição Mista com tabela de proabilidade de Moyers.

Os passos para a Análise da Dentição Mista segundo o método de Moyers estão ilustrados detalhadamente na Figura 15 (página 58). 


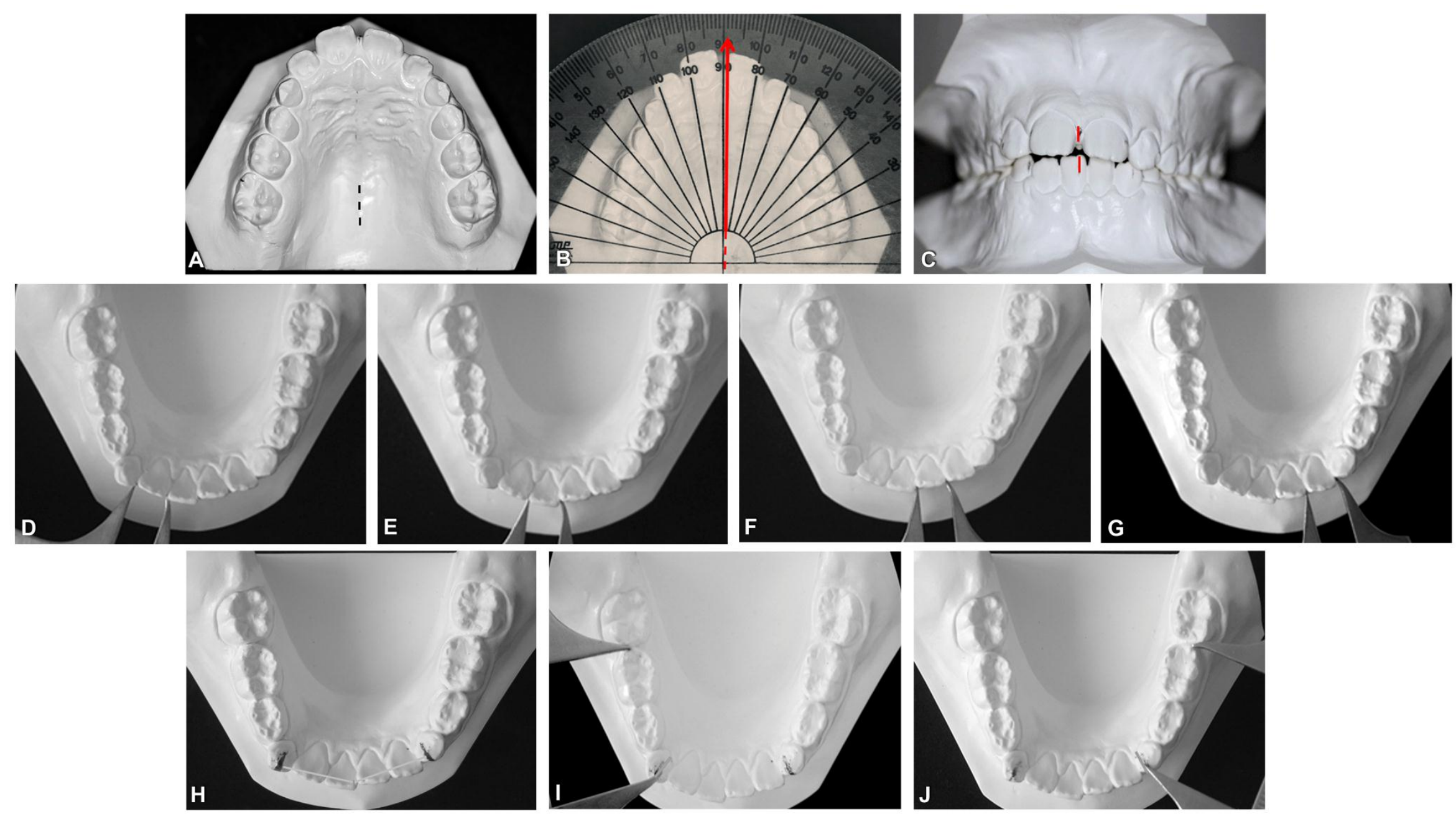

Figura 15. A, B, C- Correção das linhas médias; D, E, F, G- Mensuração do diâmetro M-D dos incisivos inferiores; H- Espaço necessário para alinhamento dos incisivos; I, J- Mensuração do espaço avaliado após alinhamento dos incisivos. 
Após a expansão palatina, período de contenção e remoção do aparelho, os pacientes foram novamente avaliados para verificar a necessidade da continuação do tratamento ortodôntico com outros tipos de aparelho, ou colocação de contenção removível.

\subsection{Análise Estatística}

Para a análise estatística dos dados fornecidos pelo programa Image J características como sexo e idade dos grupos foram comparados respectivamente por meio dos testes Qui-Quadrado e Test-t. A variabilidade da formação óssea nas radiografias de cada indivíduo ao final da disjunção até o sexto mês foi comparada entre os grupos experimental e controle por meio de modelo de equação generalizada, considerando o indivíduo como fator aleatório levando-se em conta a dependência dos dados e o tratamento como fator fixo. Para todos os modelos de equação generalizadas neste estudo foram realizadas análises de resíduos e de diagnóstico para verificar adequação aos pressupostos. Como foi observada diferença de idade entre os grupos controle e experimental, a idade entrou como fator fixo nos modelos finais. Comparação entre as médias de formação óssea foi realizada por meio de teste de Tukey apropriado para modelos generalizados. Além dos gráficos de média foram gerados gráficos de trajetórias individuais para visualizar a progressão de formação óssea de cada indivíduo ao longo do tempo. O efeito da irradiação com laser de baixa potência na dor (variável ordinal) foi avaliado utilizando-se modelo marginal para dados correlacionados longitudinais pelo método de modelos generalizados por meio do procedimento PROC GENMOD (Diggle et al., 1994) atribuindo-se ao desfecho a distribuição multinomial.

Quanto a Análise da Dentição Mista, foram gerados estimadores descritivos para cada quadrante e para a análise final que verificou se o tratamento na arcada superior influenciou o ganho de espaço na arcada inferior. Foi utilizado também modelo de equação generalizada levando em consideração o indivíduo como fator aleatório e a arcada como fator fixo. Análise de resíduo também foi realizada para verificar adequação de pressupostos do teste utilizado. Todos os procedimentos estatísticos foram realizados utilizando o programa estatístico SAS 9.3 (SAS, Cary, NC, USA) sendo que o modelo generalizado foi realizado utilizando-se o procedimento GLIMMIX. 

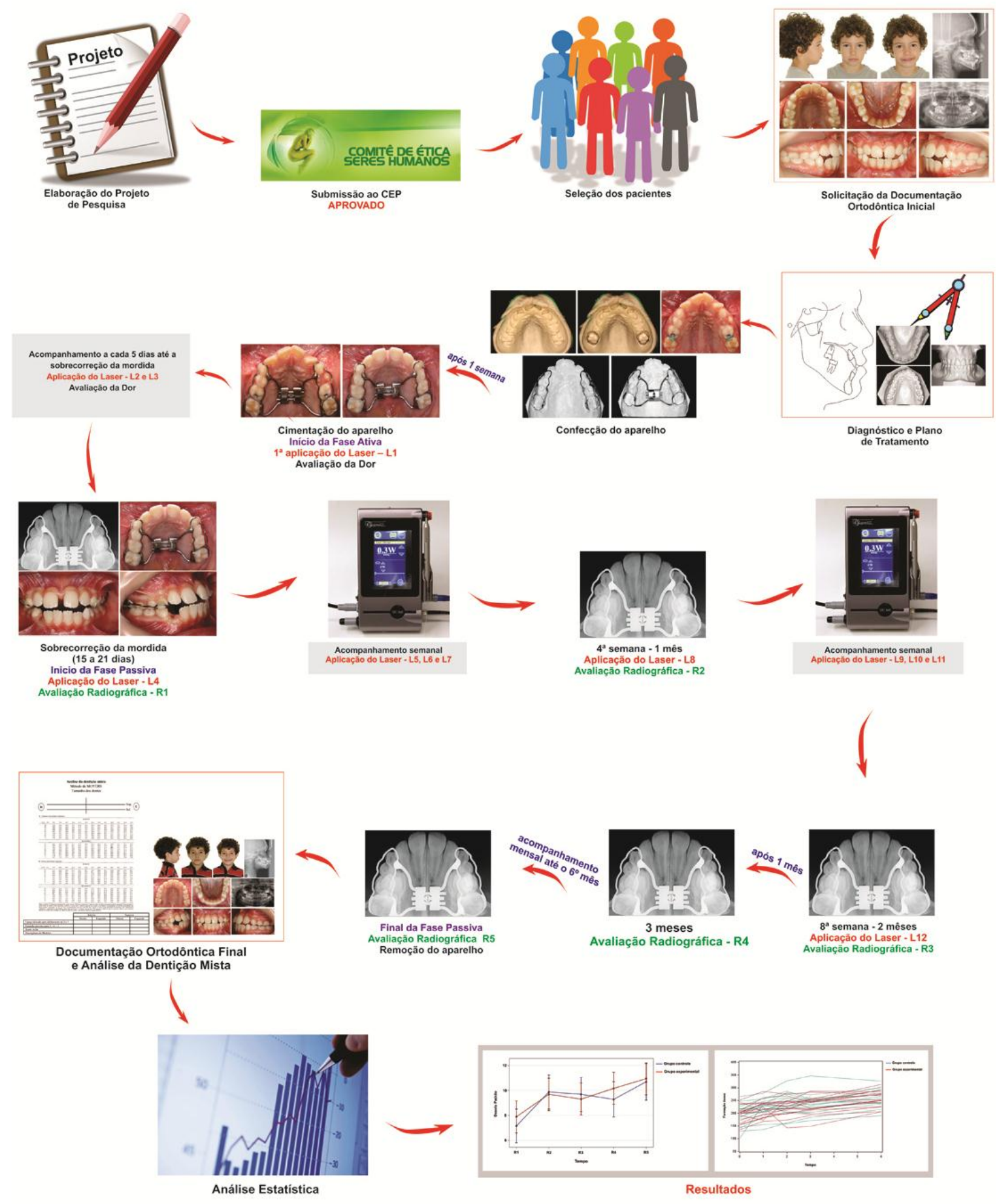

Figura 16: Fluxograma ilustrando a metodologia do estudo. 
4. Resultados 


\section{Resultados}

\subsection{Análise da Formação Óssea}

\subsubsection{Descrição da amostra}

Participaram efetivamente desta etapa da pesquisa 34 pacientes, sendo 16 pacientes no grupo controle e 18 pacientes no grupo experimental. Deste total, 18 eram do sexo masculino e 16 do sexo feminino, distribuídos aleatoriamente entre os grupos. 0 grupo controle contou com 8 integrantes do sexo masculino e 8 do sexo feminino e o grupo experimental com 10 integrantes do sexo masculino e 8 integrantes do sexo feminino. 0 grupo controle apresentou $44,4 \%$ de meninos em comparação a $55,5 \%$ do grupo experimental, porém esta diferença não foi estatisticamente significante $(p=0,7460)$.

Os meninos apresentaram idade média de 9,2 anos (Erro Padrão, EP=0,3) e as meninas com 9,1 anos (EP $=0,4)$ não sendo possível encontrar diferenças estatisticamente significantes entre os sexos ( $p=0,8377)$. A média de idade do grupo controle foi de 8,2 anos $(E P=0,2)$ e do grupo experimental 9,2 anos $(E P=0,3)$ sendo a idade dos indivíduos do grupo controle estatisticamente menor do que os indivíduos do grupo experimental $(p=$ 0,0308).

\subsubsection{Análise dos desvios padrão das radiografias}

Ao fornecer um valor de pixel para a área delimitada da radiografia (ROI), o programa Image J fornecia também um desvio padrão para este valor. A análise dos desvios padrão fornecidos pelo programa descreve a heterogeneidade ou variância das imagens. $A$ análise estatística dos dados demonstrou que os desvios não foram diferentes quando comparados entre os grupos controle e experimental nos mesmos tempos, não havendo influência do tratamento $(p=0,3278)$.

A Figura 17 (página 63) ilustra esta variação entre os grupos ao longo do tempo. 


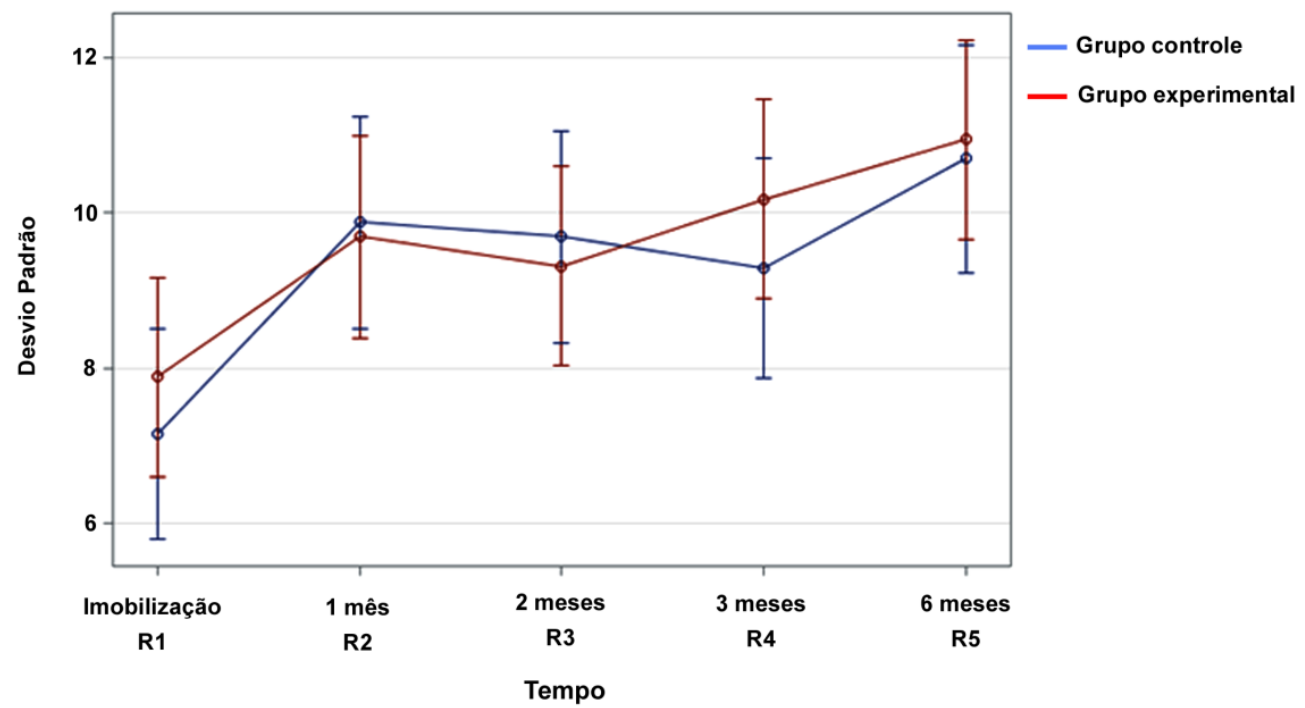

Figura 17: Variação de desvio padrão das radiografias realizadas durante tratamento de ERM para os grupos controle e experimental ao longo dos seis meses de acompanhamento, com intervalo de confiança de $95 \%$ em cada tempo gerado pela análise de modelos de equação generalizadas considerando-se indivíduos como fator aleatório e tempo $(p<0.001)$, tratamento $(p=0,3278)$ e idade como efeito fixo.

\section{A Tabela 2 mostra os valores que deram origem a figura acima.}

Tabela 2: Desvio padrão das imagens radiográficas realizadas durante tratamento de ERM para os grupos controle e experimental ao longo dos seis meses de acompanhamento.

\section{Imobilização (R1) 1 mês (R2) 2 meses (R3) 3 meses (R4) 6 meses (R5)}

\begin{tabular}{lcccccccccc} 
& $\mathrm{M}$ & $\mathrm{EP}$ & $\mathrm{M}$ & $\mathrm{EP}$ & $\mathrm{M}$ & $\mathrm{EP}$ & $\mathrm{M}$ & $\mathrm{EP}$ & $\mathrm{M}$ & $\mathrm{EP}$ \\
\cline { 2 - 10 } Controle & 6,8 & 0,4 & 9,5 & 0,8 & 9,3 & 0,6 & 8,9 & 0,8 & 10,3 & 0,6 \\
Experimental & 8,0 & 0,7 & 9,8 & 0,6 & 9,4 & 0,5 & 10,3 & 0,7 & 11,0 & 0,8 \\
p & 0,9699 & & 0,9999 & & 0,9999 & & 0,9429 & & 0,9991 & \\
\hline
\end{tabular}

$M=$ médias ; $E P=$ erro padrão

IC $95 \%$ = Intervalo de Confiança de 95\% após ajuste por comparação múltipla (Tukey-Kramer)

$\mathrm{p}=$ valor de $\mathrm{p}$ ajustados por comparação múltipla (Tukey-Kramer)

Nota: Valores de médias, intervalos de confiança e valores de $p$, obtidos no modelo de equação de estimador generalizada levando-se em consideração o indivíduo como fator aleatório e tratamento $(p=0,3278)$, tempo $(p<0.001)$ e idade $(p=$ 0,4951 ) como fatores fixos.

Após 1 mês, nas radiografias R2, R3, R4 e R5, os desvios foram maiores sendo a diferença estatisticamente significante quando comparada com a radiografia inicial (R1) $(p<0,05)$. A radiografia $R 1$ apresentou maior homogeneidade da imagem uma vez que foi obtida no momento da imobilização do parafuso (final da fase ativa e início da fase passiva) onde a área estava totalmente radiolúcida (abertura da sutura), pois não havia ainda iniciado a formação óssea. A análise dos desvios indica que após 1 mês houve início da formação óssea onde as imagens começaram a apresentar maior radiopacidade que aumentou com o tempo e consequentemente maior variabilidade nos tons de cinza. O tempo não foi estatisticamente significante para as radiografias de 1 (R2), 2 (R3), 3 (R4) e 6 (R5) meses 
quando comparadas entre si, somente quando foi realizada a comparação entre a radiografia inicial (R1) e as demais.

\subsubsection{Formação óssea}

O resultado final da análise estatística mostrou que não foi possível encontrar diferença entre os grupos com relação à formação óssea, sinalizando que o tratamento com laser de baixa potência nos parâmetros testados, não foi capaz de influenciar positivamente a formação óssea $(p=0,2273)$. A formação óssea foi influenciada apenas pelo tempo ( $p=$ 0,001).

A Figura 18 mostra esta comparação ao longo do tempo de contenção com as trajetórias individuais de formação óssea (valor de pixel) para os grupos controle e experimental. A Figura 19 mostra a comparação entre os três primeiros meses de tratamento.

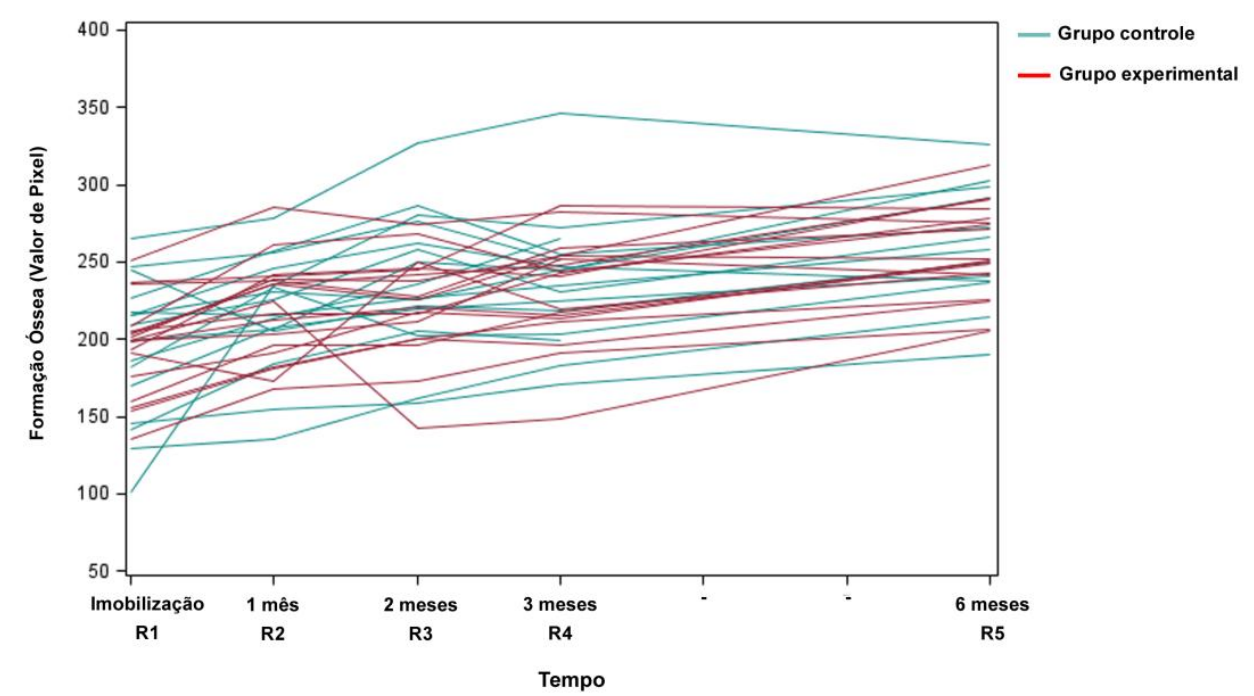

Figura 18: Trajetórias individuais de formação óssea (valor de pixel) durante tratamento de ERM para gupos controle e experimental durante seis meses de tratamento.

A Figura 18 mostra que apenas o tempo foi estatisticamente significante $(p=$ 0,001). O aumento da formação óssea ao longo do tratamento fica evidente pelo aumento da radiopacidade presente nas radiografias ao longo dos meses, em ambos os grupos.

A idade dos indivíduos foi levada em consideração na análise uma vez que houve diferença estatística significante entre os grupos $(p=0,0308)$. Portanto foi realizado ajuste estatístico desta variável com a finalidade de compensar as diferenças finais. A Figura 19 mostra as médias de formação óssea ajustadas pela idade e a Figura 20 mostra os valores sem esse ajuste com seus respectivos intervalos de confiança (95\%). 


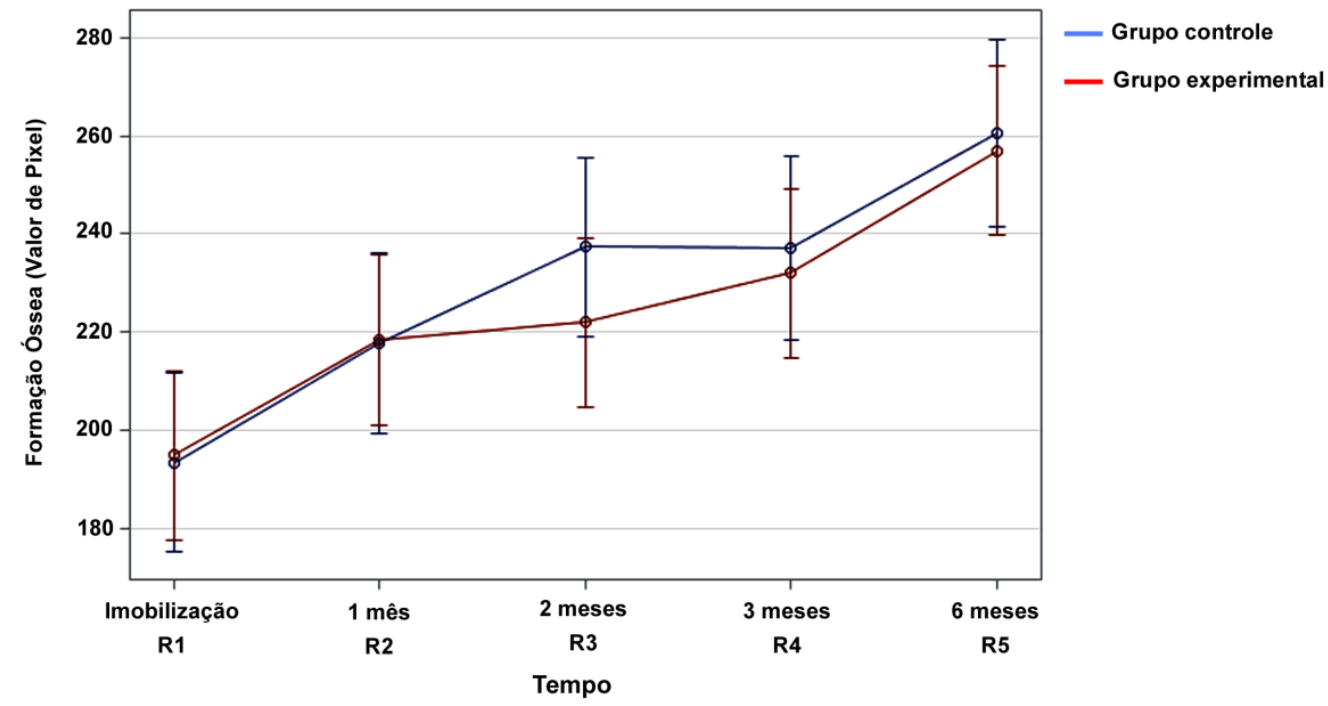

Figura 19: Formação óssea (valor de pixel) durante seis meses de tratamento com ERM para grupos controle e experimental com intervalos de confiança de $95 \%$, sem o ajuste da idade.

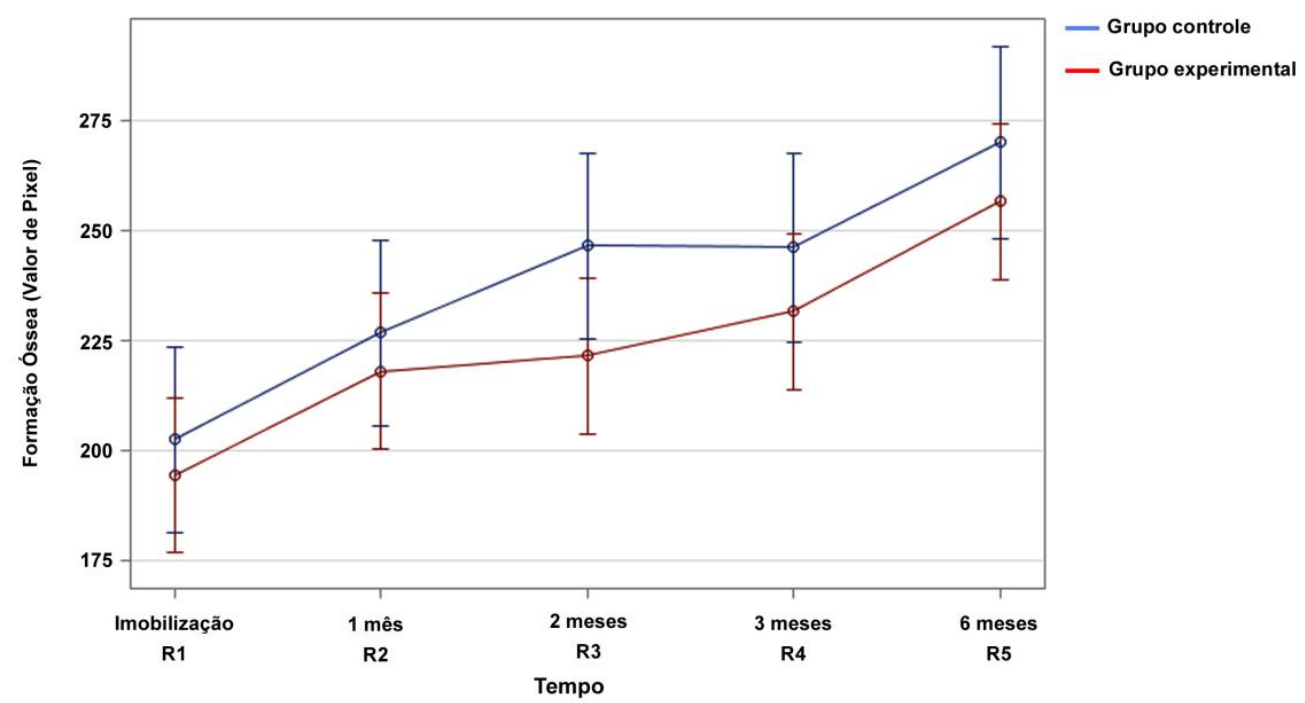

Figura 20: Formação óssea (valor de pixel) durante seis meses de tratamento com ERM para grupos controle e experimental com intervalos de confiança de $95 \%$, após o ajuste da idade.

A Tabela 3 mostra as médias sem ajuste de idade mostrando a necessidade de levar em consideração esta variável.

Tabela 3: Formação óssea sem o ajuste pela idade.

\begin{tabular}{lccccccccccc} 
& \multicolumn{2}{c}{$\begin{array}{c}\text { Imobilização } \\
\text { (R1) }\end{array}$} & \multicolumn{2}{c}{$\begin{array}{c}\text { 1 mês } \\
\text { (R2) }\end{array}$} & \multicolumn{2}{c}{$\begin{array}{c}\text { 2 meses } \\
\text { (R3) }\end{array}$} & \multicolumn{2}{c}{$\begin{array}{c}\text { 3 meses } \\
\text { (R4) }\end{array}$} & \multicolumn{2}{c}{ meses (R5) } \\
& M & EP & M & EP & M & EP & M & EP & M & EP \\
\hline Controle & 193,4 & 11,5 & 217,7 & 9,2 & 237,4 & 11,1 & 237,3 & 11,7 & 260,4 & 10,5 \\
Experimental & 194,7 & 7,1 & 216,6 & 7,9 & 221,9 & 7,6 & 232,0 & 8,0 & 256,0 & 7,1 \\
\hline
\end{tabular}

$M=$ médias ; $E P=$ erro padrão 
A Tabela 4 mostra as médias ajustadas pela idade que deram origem a Figura 20, na página 65.

Tabela 4: Formação óssea ajustada pela idade.

\begin{tabular}{lcccccccccc} 
& \multicolumn{2}{c}{$\begin{array}{c}\text { Imobilização } \\
\text { (R1) }\end{array}$} & \multicolumn{2}{c}{$\begin{array}{c}\mathbf{1} \text { mês } \\
\text { (R2) }\end{array}$} & \multicolumn{2}{c}{$\begin{array}{c}\text { 2 meses } \\
\text { (R3) }\end{array}$} & \multicolumn{2}{c}{$\begin{array}{c}\text { 3 meses } \\
\text { (R4) }\end{array}$} & \multicolumn{2}{c}{$\begin{array}{c}\text { meses } \\
\text { (R5) }\end{array}$} \\
Controle & M & EP & M & EP & M & EP & M & EP & M & EP \\
\cline { 2 - 12 } Experimental & 202,5 & 10,4 & 226,8 & 10,4 & 246,6 & 10,4 & 246,2 & 10,6 & 270,0 & 10,9 \\
p & 194,5 & 8,8 & 218,1 & 8,8 & 221,6 & 8,8 & 231,7 & 8,8 & 256,6 & 8,8 \\
\hline & 0,9998 & & 0,9996 & & 0,6634 & & 0,9826 & & 0,9911 & \\
\hline
\end{tabular}

$M=$ médias ; $E P=$ erro padrão

IC $95 \%$ = Intervalo de Confiança de 95\% após ajuste por comparação múltipla (Tukey-Kramer) $\mathrm{p}=$ valor de $\mathrm{p}$ ajustados por comparação múltipla (Tukey-Kramer)

Nota: valores de medias, intervalos de confiança e valores de $p$, obtidos no modelo de equação de estimador generalizada levando-se em consideração o individuo como fator aleatório e tratamento $(p=0,2357)$, tempo $(p<0.001)$ e idade $(p=$ 0,2372 ) como fatores fixos.

Foi comparada a formação óssea no terceiro e sexto mês especificamente em ambos os grupos e foi observado que houve diferença estatística entre os tempos demostrando que ao terceiro mês o tecido ósseo estava bem menor radiopaco que ao 60 mês ( $p=0,0249$ para o grupo controle e $p=0,0010$ para o grupo experimental).

\subsection{Sensação dolorosa}

Participaram desta etapa da pesquisa 34 pacientes, sendo 19 pacientes no grupo controle e 15 pacientes no grupo experimental. A diferença na quantidade de indivíduos entre os grupos nesta fase da pesquisa é explicada devido ao fato de que alguns participantes avaliados foram excluídos nas demais etapas do estudo, devido a falta de assiduidade às consultas de acompanhamento. Destes 34 pacientes, 18 pacientes eram do sexo masculino $(52,9 \%)$ e 16 do sexo feminino $(47,1 \%)$. Os indivíduos do sexo masculino representaram respectivamente $47,4 \%(n=9)$ do grupo controle e $60 \%(n=9)$ no grupo experimental. Embora esta diferença entre sexo nos grupos controle e experimental não tenha sido significante $(p=0,4637)$, o sexo feminino foi levemente sub-representado no grupo experimental. A média de idade no grupo controle foi de $8,3(E P=0,3)$ e 9,2 para o grupo experimental $(E P=0,3)$ sendo estatisticamente diferentes $(p=0,0542)$.

De todos os indivíduos apenas 1 em cada grupo não relatou dor em nenhum momento do estudo. A dor intensa e insuportável foi relatada por 3 pacientes $(16.7 \%)$ no grupo controle no primeiro dia e por 1 paciente $(5,6 \%)$ no segundo dia. No grupo experimental, a dor intensa e insuportável foi relatado no sexto dia por apenas 1 paciente $(7,14 \%)$. 
A comparação de sensação dolorosa entre os grupos experimentais e controle durante 14 dias foi realizada utilizando-se estimação marginal para medidas repetidas. Embora a distribuição de idade entre grupos controle e experimental tenha sido estatisticamente diferente e a distribuição de sexo não tenha apresentado diferença, estas variáveis foram consideradas no modelo final por terem apresentado diferenças pontuais e devido a reconhecida importância na formação óssea. Assim, o modelo final revelou que a chance do grupo experimental apresentar níveis mais altos de dor ao longo dos 14 dias de tratamento (fase ativa) foi 1,74 vezes maior que a chance de o grupo controle apresentar altos níveis de dor após ter sido controlado a idade e sexo no modelo com intervalo de confiança de $95 \%(0,48-6,26)$ e $p=0,3940$. Esta probabilidade, no entanto, não foi estatisticamente significante. $O$ tempo foi estatisticamente significante $(p<0,01)$ sendo comparado ao nível de dor do 140 dia, a dor foi significantemente maior até 070 dia. Começando no $8^{\circ}$ dia a percepção de dor não foi diferente do último dia. A faixa etária de 7 anos também demonstrou menos dor do que os indivíduos de 11 anos de idade $(p=0,0176)$.

As figuras abaixo representam a evolução da dor entre os grupos, sendo que a sensibilidade dolorosa foi expressa em porcentagem. A Figura 21 (página 68), mostra a presença de dor (moderada e intensa) ao longo do tratamento entre os grupos onde foi possível observar que os indivíduos do grupo experimental relataram mais dor do que os indivíduos do grupo controle, embora esta diferença não tenha disso estatisticamente significante. Nesta figura também podemos notar que houve diminuição nos relatos de dor ao longo da fase ativa, com exceção do primeiro para o segundo dia onde houve um pico em ambos os grupos. 0 gráfico de progressão de dor moderada (Figura 22, página 68), revela que o grupo experimental apresentou maior frequência de dor moderada quando comparado ao grupo controle. A evolução da dor intensa (Figura 23, página 68) mostra que houve um declínio da dor severa relatada pelos pacientes ao longo do estudo, não apresentando visualmente grande diferença entre os grupos controle e experimental. 


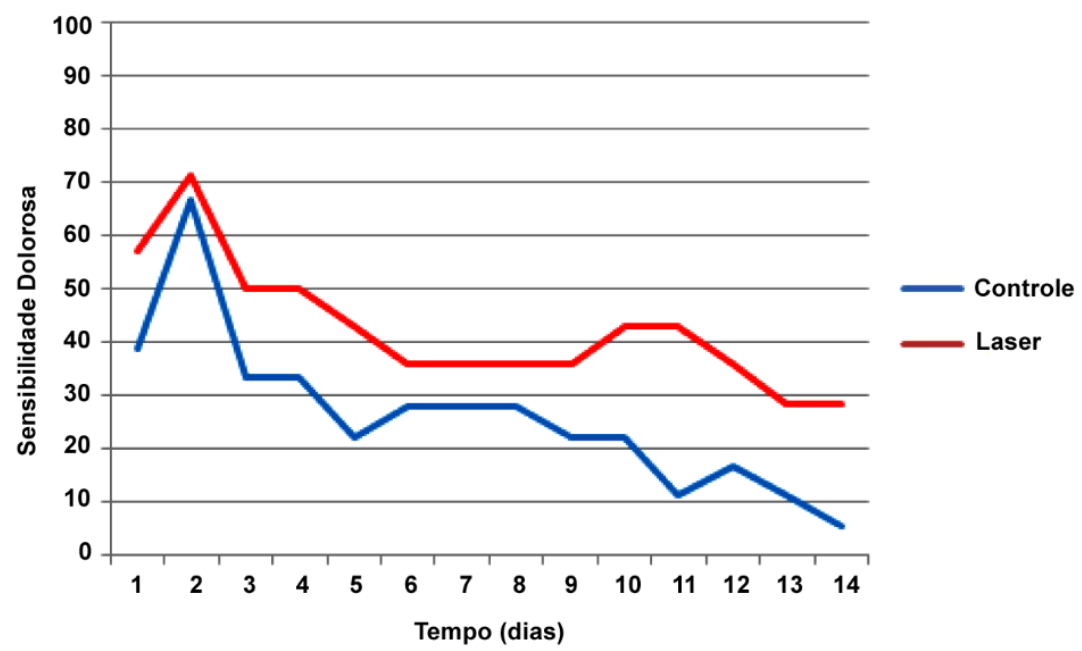

Figura 21: Presença de dor entre os grupos ao longo da fase ativa do tratamento.

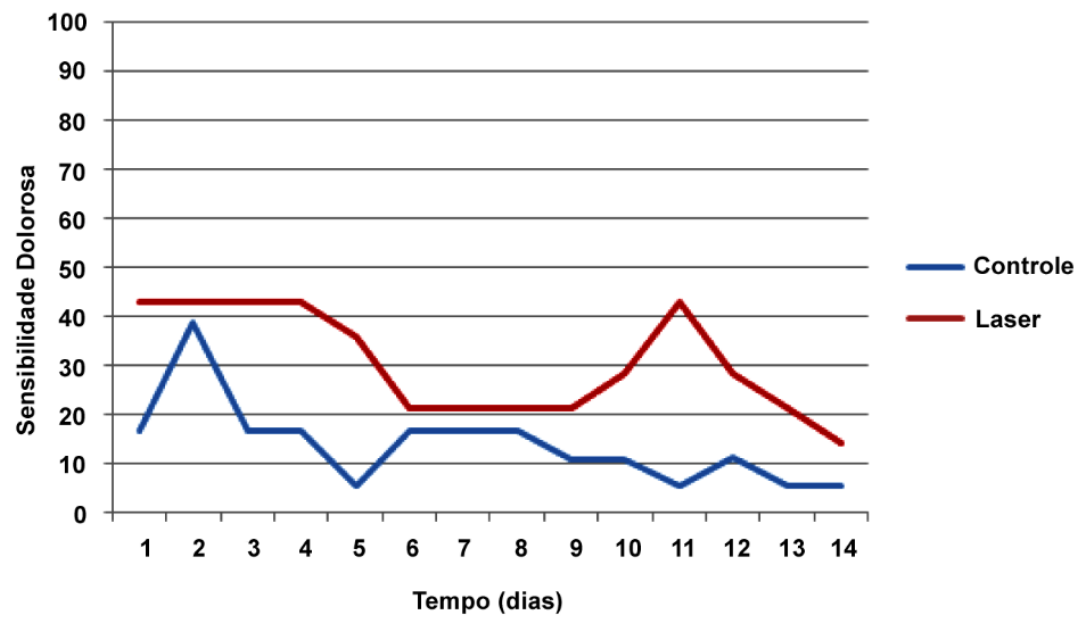

Figura 22: Evolução da dor moderada entre os grupos.

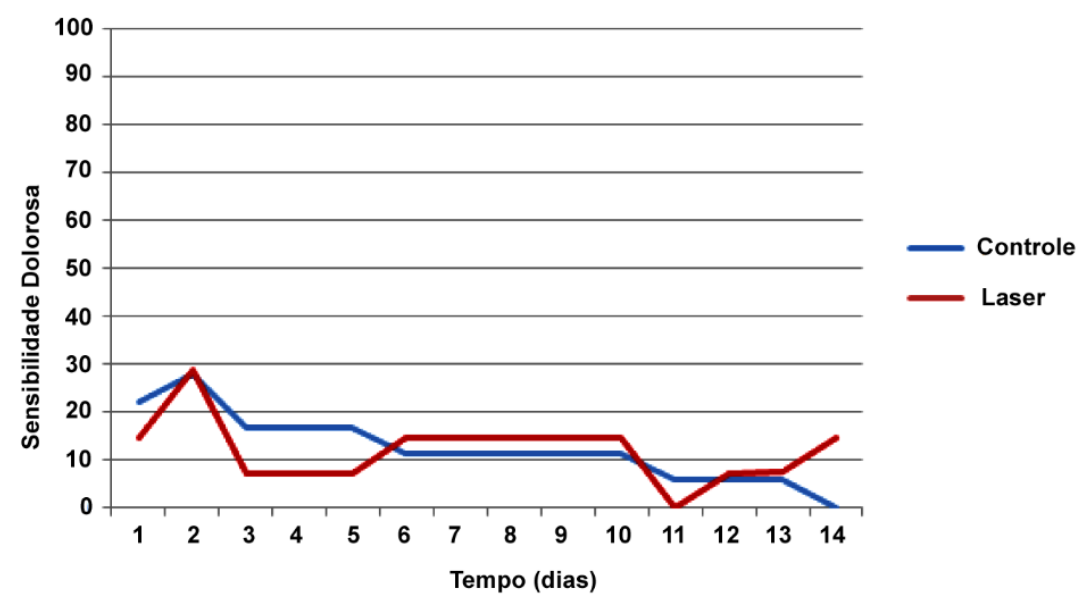

Figura 23: Evolução da dor intensa entre os grupos. 


\subsection{Análise da dentição mista (ADM)}

Foram realizadas ADM dos modelos de estudo contidos na documentação ortodôntica inicial dos indivíduos participantes da pesquisa e ao final do tratamento em uma nova documentação, para comparação antes e após o tratamento com disjunção. Dos 34 participantes da pesquisa que concluíram o tratamento, somente 31 realizaram a documentação ortodôntica final. A análise para cada indivíduo apresentava 4 medidas iniciais e 4 medidas finais, sendo que cada medida correspondia a um quadrante, perfazendo um total de 248 medidas. Nesta etapa da pesquisa os indivíduos não foram considerados em seus grupos (controle e experimental), pois o objetivo foi avaliar o espaço, não havendo influência do tratamento com laser neste aspecto. Dados como idade e sexo não foram estatisticamente significantes para esta análise, por isso não foram considerados.

A Tabela 5 mostra as médias encontradas para cada quadrante na avaliação inicial e final da ADM.

Tabela 5: Médias inicial e final para cada quadrante.

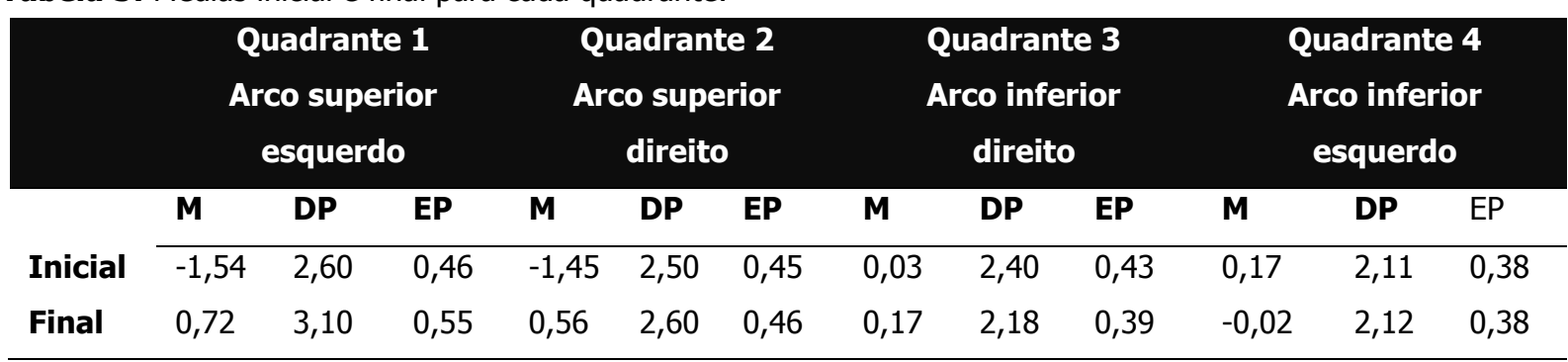

$\mathrm{M}=$ Média, $\mathrm{DP}=$ Desvio padrão, EP= Erro padrão.

A tabela acima mostra que de um modo geral houve ganho de espaço após a disjunção palatina em todos os quadrantes, com exceção do quadrante 4 que apresentou diminuição do espaço de 0,17 para -0,02. Entretanto, essa diferença não foi estatisticamente significante.

O arco superior apresentou ganhos (média de 2,18mm), é ilustrado na Tabela 6.

Tabela 6: Médias inicial e final divididas pelas arcadas superior e inferior.

\begin{tabular}{l|lccccc} 
& \multicolumn{3}{c}{$\begin{array}{c}\text { Quadrantes 1 e 2 } \\
\text { Arco superior }\end{array}$} & \multicolumn{3}{c}{$\begin{array}{c}\text { Quadrantes 3 e 4 } \\
\text { Arco Inferior }\end{array}$} \\
\cline { 2 - 7 } Inicial & M & DP & EP & M & DP & EP \\
\cline { 2 - 7 } Final & $0,64,50$ & 2,50 & 0,32 & 0,10 & 2,24 & 0,28 \\
\hline
\end{tabular}

$\mathrm{M}=$ Média, $\mathrm{DP}=$ Desvio padrão, $\mathrm{EP}=$ Erro padrão.

A Tabela 6 mostra claramente que o ganho no arco superior após a disjunção e contenção (6 meses), foram estatisticamente significantes quando comparadas as medidas 
de ADM realizadas anteriormente ao tratamento. No arco inferior, onde não foi executado nenhum tipo de tratamento, manteve-se as medidas iniciais com leve diminuição dos valores, porém as diferenças não foram estatisticamente significantes.

A Figura 24 ilustra os resultados apresentados na tabela acima onde o arco superior (em azul) mostra que houve ganho de espaço entre as análises inicial e final. $O$ arco inferior (em vermelho) mostra-se constante, não havendo diferença estatística entre as análises, evidenciando manutenção do espaço já existente no início do tratamento. Estes resultados mostram que a disjunção no arco superior foi incapaz de influenciar o arco inferior com relação ao ganho de espaço no período de tempo avaliado.

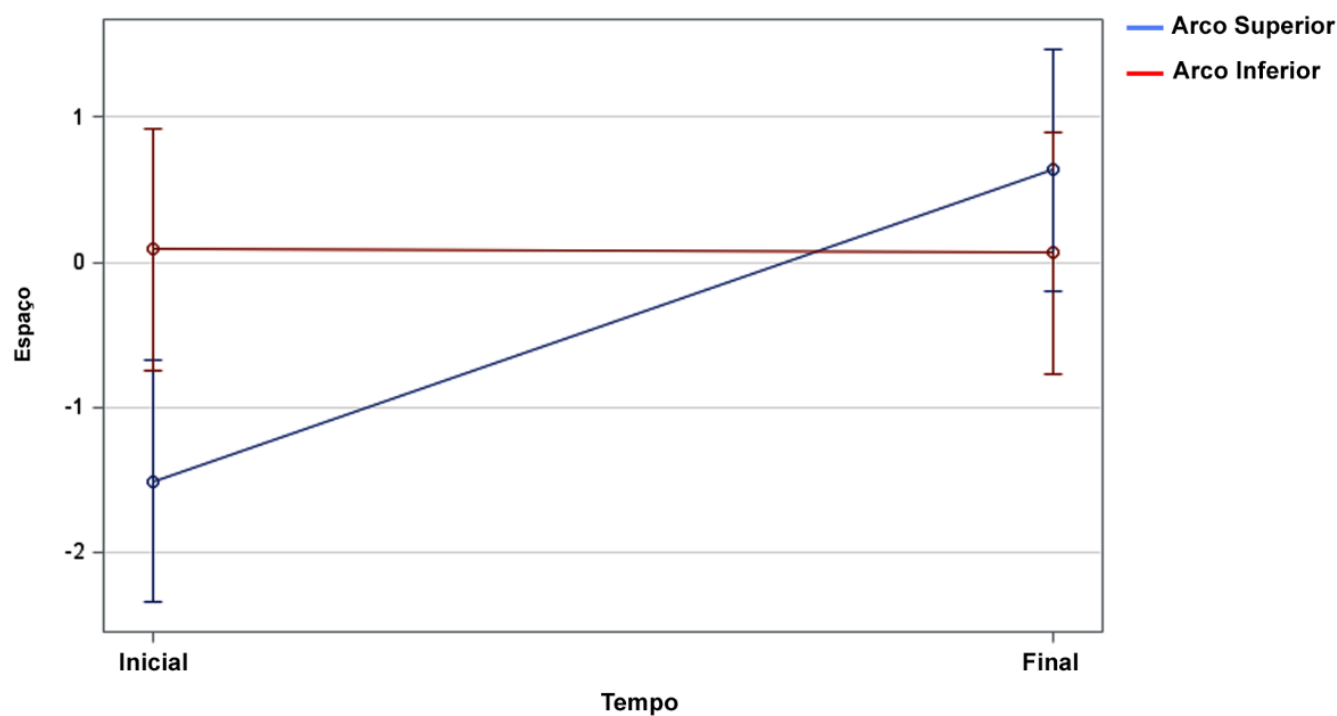

Figura 24: Ilustração gráfica mostrando a avaliação de espaço. Arcada superior apresentou ganho de espaço evidenciado pela ADM antes e após disjunção e a arcada inferior manteve-se constante com relação ao espaço já existente previamente ao tratamento. 
5. Discussãa 


\section{Discussão}

A intervenção em determinados tipos de maloclusão em pacientes jovens traz diversos benefícios e busca evitar agravamentos futuros como por exemplo, alterações ósseas irreversíveis que posteriormente devem ser corrigidas somente com procedimento cirúrgico. Dentre os fatores que influenciam a tomada de decisão quanto a intervenção em idade precoce, destaca-se o tipo de maloclusão apresentada, fase de crescimento do paciente e a possibilidade de colaboração no tratamento tanto por parte dos pacientes como também dos responsáveis. No quesito colaboração, a idade e maturidade do paciente conta muito na aceitação e adesão ao tratamento (Da Silva Filho et al., 1995; McNamara, 1996; White, 1998; Dugoni e Aubert, 2006).

O procedimento de expansão rápida da maxila, realizado pela primeira vez por Angell (1860) e posteriormente aperfeiçoado e difundido por Haas (1961) e Biederman (1968), consiste no aumento das dimensões transversais da arcada superior por meio de aparelhos disjuntores. Para que este procedimento não cause maiores transtornos e incômodos aos pacientes, o ideal é que o tratamento seja realizado antes do surto máximo de crescimento puberal que ocorre aproximadamente aos 10-11 anos para as meninas e aos 12-13 anos para os meninos. Nesta faixa etária, na maioria dos casos, ainda não ocorreu a ossificação da sutura palatina mediana, a qual tende a fusionar-se com o aumento da idade dificultando e muitas vezes inviabilizando o procedimento de disjunção convencional (Bishara e Staley, 1987; Graber \& Vanarsdall, 1996; McNamara, 2000; Proffit et al., 2007).

Participaram desta pesquisa 34 pacientes com idade entre 6 e 12 anos, sendo 18 do sexo masculino e 16 do sexo feminino, a média de idade destes pacientes foi de 9,2 anos para os meninos e 9,1 anos para as meninas. O número de pacientes que participaram deste estudo e a média de idade estão de acordo com os dados apresentados por outros autores como Cepera et al. (2012), que também avaliaram a influência do laser de baixa potência na formação óssea após disjunção e contou com a participação de 27 crianças com idade entre 8 e 12 anos, sendo a média de idade de 10,2 anos. Os autores De Melo et al. (2013) contaram com uma amostra de 31 pacientes em seu estudo onde avaliou a formação óssea por meio de radiografias digitais, sendo 11 meninas e 20 meninos, com idade média de 11,6 anos. Outros estudos que avaliaram o procedimento de disjunção sob outros aspectos continham na amostra pacientes com média de idade semelhante as citadas. No trabalho de Chung e Font (2004), a média de idade dos 20 participantes da pesquisa foi 11,7 anos. Franchi et al. (2010) utilizaram em seu estudo uma amostra de 17 pacientes com média de idade de 11,2 anos, Christie et al. (2010) contaram com a participação de 44 crianças com 
média de idade de 9,9 anos, Ugolini et al. (2016) avaliaram 33 pacientes submetidos ao procedimento de disjunção com média de idade de 8,8 anos. No presente estudo, optamos por utilizar pacientes nesta faixa etária devido a grande possibilidade de abertura de sutura e facilidade de correção de problemas oclusais.

O principal instrumento atualmente utilizado para avaliar a viabilidade da abertura da sutura é a radiografia oclusal, descrita pela primeira vez por Simpson em 1916 (Alvares e Tavano, 2002). A ascensão dos sistemas digitais para obtenção de radiografias trouxe avanços em diversas áreas da Odontologia além de benefícios aos pacientes como o menor índice de radiação. Anissi e Geibel (2014), avaliaram o sistema convencional e o sistema digital quanto a dose de radiação necessária para obtenção da imagem radiográfica e encontraram que apesar do ligeiro aumento do número de radiografias que tende a acontecer com o sistema digital, existe redução significativa na dose de irradiação aplicada no momento da tomada radiográfica. Os autores afirmam que a dose de radiação com o sistema digital é reduzida à metade quando comparado ao sistema convencional e que essa redução é decorrente do menor tempo de exposição que o sistema digital necessita. Com relação ao aumento do números de tomadas radiográficas que o sistema digital tende a propiciar, Berkhout et al. (2003) avaliaram essa questão por meio de questionários enviados a profissionais que utilizavam ambos sistemas e concluíram que os profissionais que utilizam o sistema digital são mais propensos a executarem maior número de radiografias que os dentistas que utilizam os métodos convencionais. Os autores afirmam ainda, que embora a radiografia digital intraoral utilize $50-80 \%$ menos exposição por radiação do que a película convencional, é provável que a real redução da dose seja inferior a $25 \%$, devido à maior números de tomadas radiográficas. Parece haver um consenso entre os pesquisadores com relação aos benefícios da utilização do sistema de radiografia digital principalmente quanto a redução da dose de radiação e qualidade das imagens obtidas (Versteeg et al., 1997; Hayakawa et al., 1997; Yoshiura et al., 1999a; Yoshiura et al., 1999b) embora a tendência em aumentar o número de tomadas radiográficas quando utilizado o sistema digital necessite de atenção (Berkhout et al. 2003; Anissi e Geibel, 2014).

A utilização de radiografias digitais no diagnóstico inicial da possibilidade de abertura da sutura palatina mediana, para confirmação desta abertura ao final da fase ativa e também acompanhamento da formação óssea durante a fase de contenção, foi o método escolhido nesta pesquisa, pois visa a segurança e o conforto do paciente durante as tomadas radiográficas. Os autores De Melo et al. (2013) também utilizaram o mesmo método e afirmaram que as radiografias digitais podem ser ferramentas valiosas para avaliar as alterações que ocorrem na sutura palatina durante o tratamento com ERM. 
A formação ou regeneração óssea pós disjunção é complexa e envolve vários processos (Katchburian e Arana, 2012; Junqueira e Carneiro, 2013) sendo que a estimulação das células envolvidas no sistema de secreção da matriz óssea é alvo de inúmeros estudos que buscam elucidar tal mecanismo (Dörtbudak et al., 2000; Pretel et al., 2007; De Souza Merli et al., 2012; Guzzardella et al., 2012; Crisan et al., 2015).

Um dos aspectos que este trabalho se propôs a avaliar foi a influência do laser na formação óssea da sutura palatina mediana após o procedimento de disjunção. A metodologia empregada foi a irradiação do laser de Diodo (Einsten DL, 980nm, 0,3W), uma vez por semana durante 8 semanas em 6 pontos distribuídos bilateralmente na região anterior do palato, tendo a irradiação em cada um dos pontos a duração de 10 segundos, totalizando 1 minuto por consulta semanal. A avaliação foi realizada por meio de análise no programa Image $\mathrm{J}$ de pontos previamente selecionados nas radiografias oclusais digitais obtidas no momento da imobilização do parafuso (R1), 1 mês (R2), 2 meses (R3), 3 meses (R4) e 6 meses (R5). Os resultados deste trabalho mostraram que a irradiação do laser com a utilização deste protocolo não foi suficiente para influenciar a formação óssea na sutura palatina mediana, não havendo diferença estatística entre os grupos controle e experimental. Cepera et al. realizaram em 2012, estudo semelhante onde utilizaram laser de Diodo (Twin Laser, $780 \mathrm{~nm}, 40 \mathrm{~mW}$ ) em 10 pontos distribuídos na parte anterior e posterior da maxila por 10 segundos em cada ponto. Os autores realizaram as aplicações em etapas, sendo a etapa 1 (diariamente do $1^{0}$ ao $5^{\circ}$ dia de ativação), etapa 2 (após a imobilização do parafuso expansor, durante 3 dias consecutivos), etapas 3, 4 e 5 (após a etapa 2, aos 7, 14 e 21 dias respectivamente). Após análise dos resultados obtidos por meio de avaliação das radiografias convencionais digitalizadas e analisadas pelo programa Image Tool (Image Tool, Uthscsa, TX, USA), realizadas nos tempos T1 (inicial), T2 (imobilização do parafuso), T3 (3-5 dias após a T2), T4 (30 dias após a T3), e T5 (60 dias após a T4), os autores concluíram que o laser de baixa potência influenciou o processo de regeneração óssea da sutura, acelerando a cicatrização. As diferenças na metodologia utilizada em ambos estudos e a forma de avaliação das radiografias em distintos programas podem ser a explicação para a diferença entre os resultados das pesquisas, com ênfase no tempo entre elas e no número de aplicações do laser.

Existem na literatura, diversos estudos in vitro analisando a influência do laser de baixa potência na formação óssea da sutura palatina. Um trabalho clássico é o estudo de Saito e Shimizu que em 1997, avaliaram o laser de Diodo (830nm, 100mW) durante a expansão rápida da maxila em ratos. Os pesquisadores utilizaram o método histomorfométrico para avaliar a regeneração óssea da sutura palatina e encontraram que a 
irradiação laser de baixa potência acelerou a regeneração óssea da sutura palatina mediana submetida ao procedimento de disjunção e que este efeito é dependente não só da dose total de irradiação do laser, mas também do tempo e frequência das irradiações. Santiago et al. (2012), avaliaram a influência do tratamento com laser de baixa potência Photon Lase III (DMC Equipamentos, São Carlos, SP, Brasil) sobre o processo de reparação óssea após a expansão da sutura palatina mediana em cães e observaram diferença significativa na qualidade das suturas palatinas entre os animais dos grupos controle e experimental. Os autores encontraram após análises histológicas que os tecidos conjuntivos das suturas dos animais do grupo experimental foram semelhantes às configurações originais porém com osteogênese e fibrogênese mais avançada quando comparada ao grupo controle e afirmaram que estudos adicionais são necessários para determinar quais fases são mais críticas para otimizar este processo de regeneração. Os estudos recentes de Amini et al. (2015) e Aras et al. (2015) também avaliaram o efeito da irradiação com o laser sobre a cicatrização de sutura palatina após a expansão da sutura palatina em ratos e encontraram que o laser foi capaz de aumentar a taxa de osteogênese na sutura palatina acelerando a regeneração óssea após a disjunção. Embora nosso estudo não tenha apresentado os resultados descritos acima, eles concordam com Saito e Shimizu (1987) na afirmação que tais resultados não dependem somente da dose total de irradiação do laser, mas também do tempo e frequência das irradiações, sendo esta uma das prováveis justificativas para estas diferenças.

Outro fator que influencia na ação do laser de baixa potência está relacionado aos parâmetros que cada aparelho oferece. Muitos estudos que avaliaram a ação do laser na regeneração óssea utilizaram o laser de Diodo, com variação do tempo e frequência das radiações, comprimento de onda e potência. Saito e Shimizu (1987) que foram pioneiros nesta linha de pesquisa, utilizaram o laser de Diodo com comprimento de onda de 830nm e a potência de $100 \mathrm{~mW}$, assim como Da Silva et al (2012) que também utilizaram o laser de Diodo no mesmo comprimento de onda embora a potência tenha sido $30 \mathrm{~mW}$. Santiago et al. (2012) utilizaram o equipamento Photon Lase III que possui comprimento de onda variando entre 790 a $904 \mathrm{~nm}$ e potência de 90 a $120 \mathrm{~J} / \mathrm{cm}^{2}$, Amini et al. (2015) utilizaram o equipamento com $810 \mathrm{~nm}$ e $4 \mathrm{~J} / \mathrm{cm}^{2}$ e Aras et al. (2015) utilizaram o laser de Diodo com comprimento de onda de $808 \mathrm{~nm}$ e potência de $250 \mathrm{~mW}$. Cepera et al. (2012) que assim como em nosso estudo tinham como objetivo avaliar a influência do laser de Diodo na sutura palatina mediana in vivo, utilizaram equipamento com comprimento de onda de $780 \mathrm{~nm}$ e 40mW. Jawad et al. (2013), analisando a ação de diferentes potências e tempos de irradiação com comprimento de onda de 940nm do laser de Diodo, evidenciaram a 
importância de trabalhos que avaliem a ação dos diferentes parâmetros de um mesmo equipamento. Nosso trabalho utilizou o laser de Diodo Einstein DL (DC International, Carmel, CA, USA) no comprimento de onda 980 $\mathrm{nm}$ e potência de $0,3 \mathrm{~W}(300 \mathrm{~mW})$, sendo escolhido para este estudo por haver poucos trabalhos na Odontologia que utilizaram este comprimento de onda (Azma e Safavi, 2013; Luers et al., 2014) embora nenhum deles tenha avaliado sua influência na sensação dolorosa e fotobiomodulação óssea em pacientes submetidos a expansão rápida da maxila.

Uma das principais preocupações do tratamento com aparelhos disjuntores é o tempo de contenção uma vez que a grande maioria dos pacientes são jovens e tendem a não colaborar com tratamentos demorados e incômodos. A questão central gira em torno da remoção do aparelho sem que ocorra recidivas, para isto é necessário que a formação óssea na sutura palatina mediana tenha se concretizado de forma plena, caso contrário a remoção do aparelho disjuntor pode levar a recidiva da maloclusão. Neste contexto, a grande maioria dos autores afirma enfaticamente sobre a necessidade de um período mínimo de 6 meses de contenção após o final da fase ativa da disjunção (McNamara, 1996; Simões et al., 2003; Da Silva Filho et al., 2006; Cepera et al., 2008; Da Silva Filho et al., 2008; Lione et al., 2008; Martins et al., 2009, Franchi et al., 2010; De Melo et al., 2013). O trabalho De Melo et al. (2013), analisou a densidade da sutura palatina mediana por meio de radiografias digitais antes do procedimento de ERM, imediatamente após a expansão desejada (final da fase ativa) e ao final de 3 meses de contenção de 31 pacientes com a finalidade de avaliar se este período seria suficiente para reparação óssea. Os autores encontraram que a densidade óptica foi reduzida nas radiografias após a expansão e aos 3 meses de contenção em comparação com a radiografia inicial. Concluíram que a formação óssea não ocorreu como esperado após 3 meses e que um período de contenção maior pode ser necessário para que ocorra a reparação óssea. Simões et al. (2003) avaliaram por meio de radiografias digitalizadas, a densidade óptica da sutura palatina mediana em 109 radiografias de 37 pacientes, previamente ao tratamento, após a abertura da sutura (final da fase ativa) e após 3 meses de contenção. Os autores encontraram que houve diminuição da densidade óptica ao final da fase ativa e aumento gradativo até o final do terceiro mês, e que a densidade óptica ao final do terceiro mês não foi estatisticamente significante quando comparada com a radiografia inicial pré tratamento. Com base nos resultados, os autores sugerem que ao terceiro mês de contenção já ocorreu formação óssea, no entanto, este tecido pode estar ainda imaturo, sendo importante diferenciar estes dois estágios.

Este trabalho comparou a formação óssea aos 3 meses e ao final do tratamento após 6 meses de contenção. Foi encontrado que o valor de pixel obtido nestes diferentes 
tempos foi estatisticamente significante, ou seja, o valor aumentou do $3^{\circ}$ para o $6^{\circ}$ mês, indicando que aos três meses ainda não ocorreu a formação óssea desejada ou que este tecido ósseo ainda não está maduro o suficiente para suportar as forças fisiológicas intrabucais sem que ocorram recidivas. Embora a metodologia empregada para avaliar esta variável tenha sido diferente, nossos resultados estão de acordo com os encontrados por De Melo et al. (2013) e outros autores que defendem maior tempo de contenção com a finalidade de evitar recidivas (McNamara, 1996; Simões et al., 2003; Da Silva Filho et al., 2006; Da Silva Filho et al., 2008; Lione et al., 2008; Martins et al., 2009, De Melo et al., 2013), ainda que existam na literatura autores que preconizem tempo de contenção inferior a 6 meses (Angell, 1860; Ekastrom et al., 1977; Ten Cate et al., 1977; Bell, 1982).

Os incômodos causados pelo tratamento e pelo tempo de contenção são comunmente relatados pelos pacientes, sendo a sensação dolorosa presente durante a fase de ativação do parafuso uma queixa frequente. Joviliano et al. (2008) conseguiram comprovar em seu estudo que ocorre ativação de estruturas cerebrais relacionadas a nocicepção durante o procedimento de disjunção palatina em camundongos. Os autores afirmam que ativação do aparelho pode provocar sensação dolorosa em humanos. Gecgelen et al. (2012) encontraram níveis de cortisol aumentado em crianças submetidas ao procedimento de disjunção, indicando estresse e ansiedade causados pelo tratamento.

A ocorrência de sensação dolorosa durante o tratamento de ERM parece estar intimamente relacionado a idade dos pacientes. Pacientes mais jovens tendem a apresentar menor sensibilidade a dor, o que pode estar relacionado com a facilidade de abertura da sutura quando esta ainda não iniciou o processo de consolidação (Haas, 1970, Handelman, 1997; Handelman et al., 2000; Needleman et al., 2000). Baldini et al. (2015) investigaram a influência de dois protocolos de ativação sobre a percepção dolorosa em 112 indivíduos (54 masculinos e 58 femininos), com média de idade de 11 ( \pm 1,8 anos). Os pacientes foram divididos em 2 grupos: no primeiro grupo foi realizado 1 ativação/dia e no segundo 2 ativações/dia. Os autores observaram por meio das avalições em escalas visuais de dor que os indivíduos que foram submetidos a 2 ativações diárias relataram maior sensação dolorosa do que os indivíduos submetidos a apenas 1 ativação diária. Outro achado dos autores que influenciaram no resultado da pesquisa foi com relação ao sexo e idade, sendo que os pacientes mais jovens e do sexo feminino foram mais sensíveis ao protocolo com 2 ativações/dia. Os autores concluíram que uma menor expansão diária está relacionada a menor dor e que essa sensação dolorosa pode ser influenciada pelo sexo e maturação esquelética dos indivíduos. Needleman et al. (2000) em estudo semelhante avaliando as mesmas variáveis também encontraram a mesma relação da dor com a taxas de expansão 
maiores (2 ativações diárias) embora o sexo e a idade não tenham apresentado diferença estatística nesse estudo.

A utilização de lasers em procedimentos ortodônticos que provoquem dor com o intuito de diminuir esta sensação tem crescido entre os profissionais da área. Diversos autores tem relatado resultados positivos da ação do laser nas odontalgias decorrentes de movimentação dentária e outros procedimentos com finalidade ortodôntica que causam dor, como por exemplo, extração de pré-molares e inserção de elásticos para separação interproximal (Lim et al., 1995; Turhani et al., 2006; Tortamano et al., 2009; Doshi-Mehta e Bhad-Patil, 2012).

No presente estudo buscou-se avaliar por meio de escala visual analógica de dor, baseada na "Wong-Baker Faces Pain Scale" (FPS) (Garra et al., 2013; Baldini et al., 2015), se o laser de baixa potência foi capaz de influenciar na sensação dolorosa provocada pelo procedimento de disjunção. Encontramos que não houve diferença estatística entre os grupos controle e experimental embora a ausência de dor tenha sido relatada com maior frequência no grupo controle. Sabe-se que o grupo experimental apresentou média de idade maior ( 9,2 anos) quando comparado ao grupo controle (8,3 anos) e que esta diferença foi estatisticamente significante, podendo ser uma das justificativas para o grupo experimental ter reportado maior sensação dolorosa durante a fase ativa do tratamento, levando a crer que a idade influenciou na sensação dolorosa e não o procedimento de disjunção, uma vez que este foi o mesmo para todos os pacientes. No presente estudo, após terem sido controlados os fatores sexo e idade, foi encontrado que os pacientes na faixa etária de 7 anos demonstraram menor dor que as crianças de 11 anos de idade, ao contrário do que foi exposto acima por Baldini et al. (2015) que encontraram uma relação de maior dor em paciente de menor idade e do sexo feminino e do exposto por Needleman et al. (2000) que não encontraram influência da idade nos resultados. Com relação a influência do sexo, os resultados encontrados nesta pesquisa diferem de Baldini et al. (2015) que não encontraram influência desta variável na sensibilidade dolorosa e concordam com Needleman et al. (2000) que assim como em nosso estudo, não encontraram diferença estatística entre os sexos.

As principais modificações descritas após o procedimento de disjunção normalmente são reportadas ao arco superior onde o primeiro sinal clinico de abertura da sutura é o aparecimento de diastema entre os incisivos centrais. Haas (1965, 1970), já descreveu esta alteração como um sinal clássico do tratamento e indicativo de sucesso na abertura da sutura. No presente trabalho foi notado o diastema entre os incisivos centrais em todos indivíduos que participaram da pesquisa, estando de acordo com outros pesquisadores (Bishara e Staley, 1987, Da Silva Filho et al., 1995; Lagravère et al., 2006; Perillo et al., 
2014). Outras alterações frequentemente descritas no arco superior, porém não analisadas em nosso estudo são a abertura e aumento da permeabilidade na cavidade nasal, deslocamento da maxila para frente e para baixo, aumento da largura interorbital e maxilar (Haas, 1970; Da Silva Filho et al., 1995; Chung e Font, 2004, Lagravère et al., 2006; Christie et al., 2010; Izuka et al., 2015).

O ganho de espaço no arco superior com consequente aumento de perímetro e da distância intermolar, decorrente da expansão das dimensões transversais das maxila é frequentemente relatado entre os autores (Bishara e Staley, 1987; Adkins et al., 1990; McNamara et al., 2003; Lagravère et al., 2006; Lagravère et al., 2010; Mutinelli et al., 2008; Domann et al., 2011; Wong et al., 2011; D'Souza et al., 2015). Adkins et al. (1990) ressalta a importância de prever mudanças no perímetro do arco para uma determinada quantidade de expansão. Os autores afirmam que esta previsão é muito útil no planejamento terapêutico de casos que necessitem de expansão rápida da maxila, podendo facilitar o tratamento ortodôntico sem extrações. No presente estudo mostrou que ao final do tratamento, os pacientes submetidos a disjunção apresentaram ganho de espaço considerável neste arco. Na situação inicial, onde a ADM foi realizada previamente ao procedimento de disjunção, a média de espaço no arco superior foi de $-1,54 \mathrm{~mm}$, sendo o valor negativo um indicativo de falta de espaço. Após o procedimento de disjunção, esse valor passou para $+0,64 \mathrm{~mm}$ indicando um aumento médio do perímetro do arco superior de 2,18mm. Este resultado está de acordo com as diferentes pesquisas citados que também relataram esse aumento do perímetro e das dimensões transversais deste arco após ERM.

No arco inferior, no entanto, embora existam poucos estudos analisando o espaço após ERM, existe uma divergência de informações quanto a este aspecto. Ugolini et al. (2016) investigaram os efeitos indiretos nas dimensões do arco mandibular de pacientes submetidos a ERM após 1 ano e encontraram um aumento de 1,9mm na distância intermolar mandibular destes pacientes. Os autores Baccetti et al. (2001) e Grassia et al. (2015) também relataram em seus estudos um aumento do perímetro no arco inferior em pacientes submetidos a ERM na dentição mista.

Os autores Lagravère et al. realizaram em 2006 uma meta-análise que buscou trabalhos que avaliassem as mudanças imediatas decorrentes do tratamento de ERM e afirmaram que apesar de alguns autores relatarem expansão indireta no arco inferior (Baccetti et al., 2001; Grassia et al., 2015; Ugolini et al., 2016), os resultados encontrados na meta-análise não identificaram qualquer mudança significativa nas dimensões do arco mandibular. Os autores afirmaram ainda que são necessários mais estudos avaliando este parâmetro uma vez que estas alterações poderiam ser temporárias e poderiam apresentar 
recidiva após um certo período. Estas afirmações estão de acordo com Bishara e Staley (1987) que afirmaram que as alterações na dimensão do arco inferior após a ERM não são significantes e que tendem a apresentar recidiva após finalizado o tratamento.

O presente estudo está de acordo com os trabalhos avaliados na meta-análise de Lagravère et al. (2006) e Bishara e Staley (1987) pois observamos que o perímetro do arco inferior se mostra constante nas análises iniciais e finais evidenciando manutenção do espaço já existente no início do tratamento, sendo a ERM incapaz de influenciar a arcada inferior com relação ao espaço, em um período de 6 meses após o procedimento de disjunção.

Parece claro que o laser de baixa potência possui efeitos positivos na regeneração óssea da sutura palatina mediana em estudos que utilizaram metodologias in vitro, no entanto, o número limitado de trabalhos que utilizaram metodologias in vivo não permite extrapolar com segurança estes resultados. O grande número de aparelhos de lasers de baixa potência existentes no mercado, com grande variação nos parâmetros como comprimento de onda, potência, além de diferenças metodológicas quanto ao tempo e frequência das irradiações, padronização das radiografias e programas de análises são alguns dos pontos desfavoráveis para a comparação entre os estudos. São necessárias mais pesquisas que visem padronizar e definir critérios para a utilização do laser de baixa potência como estimulador da formação óssea em procedimentos de expansão rápida da maxila.

Os resultados apresentados em neste trabalho indicam maior necessidade de pesquisas na área de laserterapia em procedimentos de disjunção levando-se em consideração outros protocolos. Também é importante a padronização da metodologia empregada nestas avaliações para melhor comparação entre os resultados. São necessários também, mais estudos que avaliem a influência da ERM nas dimensões do arco inferior em diferentes tempos após a disjunção. 
6. Canclusãa 


\section{CONCLUSÃo}

1. O laser de baixa potência não influenciou na formação óssea da sutura palatina mediana após o procedimento de ERM nos parâmetros (980nm, 0,3W) e de acordo com a metodologia utilizada neste trabalho.

2. A formação óssea aos 3 meses de contenção obteve níveis de radiopacidade menor que aos 6 meses.

3. O laser de baixa potência não influenciou na sensibilidade dolorosa durante a fase ativa do tratamento de ERM.

4. Houve ganho de espaço no arco superior após ERM, porém o arco inferior não sofreu alteração. 
Referencias 


\section{REFERÊNCIAS*}

1. Adkins MD, Nanda RS, Currier GF. Arch perimeter changes on rapid palatal expansion. Am J Orthod Dentofacial Orthop. 1990;97:194-9.

2. Adrian JC. Pulp effects of neodymium laser. A preliminary report. Oral Surg, Oral Med, Oral Pathol. 1977;44:301-5.

3. Adrian JC, Bernier JL, Sprague WG. Laser and dental pulp. J Am Dent Ass. 1971;83:113.

4. Alvares LC, Tavano O. Curso de Radiologia em Odontologia. São Paulo: Santos; 2002.

5. Amini F, Najaf Abadi MP, Mollaei M. Evaluating the effect of laser irradiation on bone regeneration in midpalatal suture concurrent to rapid palatal expansion in rats. J Orthod Sci. 2015;4:65-71.

6. Angell, EH. Treatment of irregularity of the permanent or adult teeth. Dent Cosmos. $1860 ; 1: 540-544$.

7. Angle EH. Bone Growing. Dental Cosmos. 1910;52:261.

8. Anissi HD, Geibel MA. Intraoral radiology in general dental practices - a comparison of digital and film-based X-ray systems with regard to radiation protection and dose reduction. Rofo. 2014;186:762-7.

9. Aras MH, Erkilic S, Demir T, Demirkol M, Kaplan DS, Yolcu U. Effects of low-level laser therapy on osteoblastic bone formation and relapse in an experimental rapid maxillary expansion model. Niger J Clin Pract. 2015;18:607-11.

10. Azma E, Safavi N. Diode laser application in soft tissue oral surgery. J Lasers Med Sci. 2013;4:206-11.

11. Bahrololoomi Z, Ezoddini F, Halvani N. Comparison of Radiography, Laser Fluorescence and Visual Examination for Diagnosing Incipient Occlusal Caries of Permanent First Molars. J Dent (Tehran). 2015;12:324-32.

12. Baldini A, Nota A, Santariello C, Assi V, Ballanti F, Cozza P. Influence of activation protocol on perceived pain during rapid maxillary expansion. Angle Orthod. 2015;85:1015-20.

13. Baptista A, Kato IT, Prates RA, Suzuki LC, Raele MP, Freitas AZ, Ribeiro MS. Antimicrobial photodynamic therapy as a strategy to arrest enamel demineralization: a short-term study on incipient caries in a rat model. Photochem Photobiol. 2012;88:5849.

14. Baccetti T, Franchi L, Cameron CG, McNamara JA Jr. Treatment timing for rapid maxillary expansion. Angle Orthod 2001;71:343-50.

15. Bell RA. A review of maxillary expansion in relation to rate of expansion and patient's age. Am J Orthod. 1982;81:132-7. 
16. Berkhout WE, Sanderink GC, Van der Stelt PF. Does digital radiography increase the number of intraoral radiographs? A questionnaire study of Dutch dental practices. Dentomaxillofac Radiol. 2003;32:124-7.

17. Betts NJ, Vanarsdall RL, Barber HD, Higgins-Barber $K$, Fonseca RJ. Diagnosis and treatment of transverse maxillary deficiency. Int J Adult Orthodon Orthognath Surg. $1995 ; 10: 75-96$.

18. Biederman, W. A hygienic appliance for rapid expansion. J Pract Orthod. 1968;2:67-70.

19. Bishara SE, Staley RN. Maxillary expansion: Clinical implications. Am J Orthod Dentofacial Orthop. 1987;91:3-14.

20. Brugnera Júnior A, Villa RG, Genovese WJ. Laser na Odontologia. São Paulo: Pancast; 1991.

21. Capelozza Filho L, Da Silva Filho OM. Expansão Rápida da Maxila: Considerações Gerais e Aplicação Clínica. Parte I. R Dental Press Ortodon Ortop Facial. 1997a;2:88-102

22. Capelozza Filho L, Da Silva Filho OM. Expansão Rápida da Maxila: Considerações Gerais e Aplicação Clínica. Parte II. . R Dental Press Ortodon Ortop Facial. 1997b;2:86-108.

23. Carroll JD, Milward MR, Cooper PR, Hadis M, Palin WM. Developments in low level light therapy (LLLT) for dentistry. Dent Mater. 2014;30:465-75.

24. Carvalho-Lobato P, Garcia VJ, Kasem K, Ustrell-Torrent JM, Tallón-Walton V, Manzanares-Céspedes MC. Tooth movement in orthodontic treatment with low-level laser therapy: a systematic review of human and animal studies. Photomed Laser Surg. 2014;32:302-9.

25. Cepera F, Angelieri F, Bommarito S, Siqueira DF. Low intensity laser effects on maxilla rapid expansion. Ortodontia SPO. 2008;41:222-6.

26. Cepera F, Torres FC, Scanavini MA, Paranhos LR, Capelozza Filho L, Cardoso MA, Siqueira DC, Siqueira DF. Effect of a low-level laser on bone regeneration after rapid maxillary expansion. Am J Orthod Dentofacial Orthop. 2012;141:444-50.

27. Chang JY, McNamara JA Jr, Herberger TA. A longitudinal study of skeletal side effects induced by rapid maxillary expansion. Am J Orthod Dentofacial Orthop. 1997;112:330-7.

28. Christie $\mathrm{KF}$, Boucher $\mathrm{N}$, Chung $\mathrm{CH}$. Effects of bonded rapid palatal expansion on the transverse dimensions of the maxilla: A cone-beam computed tomography study. Am J Orthod Dentofacial Orthop. 2010;137:579-85.

29. Chung $\mathrm{CH}$, Font $\mathrm{B}$. Skeletal and dental changes in the sagittal, vertical, and transverse dimensions after rapid palatal expansion. Am J Orthod Dentofacial Orthop. 2004;126:569-75.

30. Consolaro A, Rebellato Júnior V, Consolaro MFMO, Carvalho Júnior JAR. Lesões necróticas na disjunção palatina: explicação e prevenção. $R$ Dental Press Ortodon Ortop Facial. 2009;14:20-6. 
31. Crisan L, Soritau O, Baciut M, Baciut G, Crisan BV. The influence of laser radiation on human osteoblasts cultured on nanostructured composite substrates. Clujul Med. 2015;88:224-32.

32. Da Silva AP, Petri AD, Crippa GE, Stuani AS, Stuani AS, Rosa AL, Stuani MB. Effect of low-level laser therapy after rapid maxillary expansion on proliferation and differentiation ofosteoblastic cells. Lasers Med Sci. 2012;27:777-83.

33. Da Silva Filho OG. Expansão Rápida da Maxila: um ensaio sobre a sua instabilidade. R Dental Press Ortodon Ortop Facial. 2003;8:17-36.

34. Da Silva Filho OG, Ferrari Júnior FM, Aiello CA, Zopone N. Correction of posterior crossbite in the primary dentition. J Clin Pediatr Dent. 2000;24:165-80.

35. Da Silva Filho OG, Graziani GF, Lauris RCMC, Lara TS. Midpalatal suture ossification post rapid palatal expansion: a radiographic study. $\mathrm{R}$ Dental Press Ortodon Ortop Facial. 2008;13:124-31.

36. Da Silva Filho OG, Lara TS, Da Silva HC, Bertoz FA. Post expansion evaluation of the midpalatal suture in children submitted to rapid palatal expansion: a CT study. J Clin Pediatr Dent. 2006;31:142-8.

37. Da Silva Filho OG, Montes LA, Torelly LF. Rapid maxillary expansion in the deciduous and mixed dentition evaluated through posteroanterior cephalometric analysis. Am J Orthod Dentofacial Orthop. 1995;107:268-75.

38. De Melo M de F, Melo SL, Zanet TG, Fenyo-Pereira M. Digital radiographic evaluation of the midpalatal suture in patients submitted to rapid maxillary expansion. Indian J Dent Res. 2013;24:76-80.

39. Derichsweiler, H. La disjonction de la suture palatine mediane. In: Congresso of the European Orthodontics Society Transations. Europ Orthodont Soc Trans. 1953;1:257-65.

40. De Souza Merli LA, de Medeiros VP, Toma L, Reginato RD, Katchburian E, Nader HB, Faloppa F. The low level laser therapy effect on the remodeling of bone extracellular matrix. Photochem Photobiol. 2012;88:1293-301.

41. Diggle PJ, Liang KY, Zeger SL. Analysis of Longitudinal Data. Oxford: Oxford Science; 1994.

42. D'Souza IM, Kumar HC, Shetty KS. Dental arch changes associated with rapid maxillary expansion: A retrospective model analysis study. Contemp Clin Dent. 2015;6:51-7.

43. Domann CE, Kau CH, English JD, Xia JJ, Souccar NM, Lee RP. Cone beam computed tomography analysis of dentoalveolar changes immediately after maxillary expansion. Orthodontics (Chic.). 2011;12:202-9.

44. Dörtbudak O, Haas R, Mallath-Pokorny G. Biostimulation of bone marrow cells with a diode soft laser. Clin Oral Implants Res. 2000;11:540-5.

45. Doshi-Mehta G, Bhad-Patil WA. Efficacy of low-intensity laser therapy in reducing treatment time and orthodontic pain: a clinical investigation. Am J Orthod Dentofacial Orthop. 2012;141:289-97. 
46. Dugoni SA, Aubert MM. Orthodontic treatment in the early mixed dentition: is this the optimum time to start care? J Calif Dent Assoc. 2006;34:807-12.

47. Ekastrom C, Henrikson CO, Jensen R. Mineralization in the midpalatal suture after orthodontic expansion. Am J Orthod Dentofacial Orthop. 1977;71:449-55.

48. Fisher SE, Frame JW. The effects of the carbono dioxide surgical laser on oral tissues. $\mathrm{Br}$ J Maxillofac Surg. 1984;22:414-25.

49. Frame JW. Carbon dioxide laser surgery for benign oral lesions. $\mathrm{Br}$ Dent J. 1985;158:123-8.

50. Franchi L, Baccetti T, Lione R, Fanucci E, Cozza P. Modifications of midpalatal sutural density induced by rapid maxillary expansion: A low-dose computed-tomography evaluation. Am J Orthod Dentofacial Orthop. 2010;137:486-8.

51. Garra G, Singer AJ, Domingo A, Thode HC. The Wong-Baker pain FACES scale measures pain, not fear. Pediatr Emerg Care. 2013;29:17-20.

52. Garib DG, Henriques JF, Carvalho PE, Gomes SC. Longitudinal effects of rapid maxillary expansion. Angle Orthod. 2007;77:442-8.

53. Gecgelen M, Aksoy A, Kirdemir P, Doguc DK, Cesur G, Koskan O, Ozorak O. Evaluation of stress and pain during rapid maxillary expansion treatments. J Oral Rehabil. 2012;39:767-75.

54. Gift AG. Visual analogue scales: measurement of subjective phenomena. Nurs Res $1989 ; 38: 286-8$.

55. Glez D, Hourdin S, Sorel O. Er:YAG laser in periodontics and implication in the orthodontic treatment plan. Orthod Fr. 2010;81:19-26.

56. Goldman L, Gray JA, Goldman J, Goldman B, Meyer R. Effects of laser impacts on teeth. J Am Dent Ass. 1965;70:601-6.

57. Graber TM, Vanarsdall RL. Ortodontia: principios e tecnicas atuais. Rio de Janeiro: Guanabara Koogan; 1996.

58. Grassia V, d'Apuzzo F, Jamilian A, Femiano F, Favero L, Perillo L. Comparison between rapid and mixed maxillary expansion through an assessment of arch changes on dental casts. Prog Orthod. 2015;16:1-7.

59. Guzzardella GA, Fini M, Torricelli P, Giavaresi G, Giardino R. Laser Stimulation on Bone Defect Healing: An In Vitro Study. Lasers Med Sci. 2002;17:216-20.

60. Hakimiha N, Khoei F, Bahador A, Fekrazad R. The susceptibility of Streptococcus mutans to antibacterial photodynamic therapy: a comparison of two different photosensitizers and light sources. J Appl Oral Sci. 2014;22:80-4.

61. Hass AJ. Rapid expansion on the maaxillary dental arch and nasal cavity by opening the midpalatal suture. Angle Orthod 1961;31:73-90.

62. Haas AJ. The treatment of maxillary deficiency by opening the midpalatal suture. Angle Orthod. 1965;35:200-17. 
63. Haas AJ. Palatal expansion: just the beginning of dentofacial orthopedics. Am J Orthod. 1970;57:219-55.

64. Haas AJ. Rapid palatal expansion: a recommented pre requisito to class III treatmment. Europ Orthodont Soc Trans. 1973;1:218.

65. Haas AJ. Long-term post-treatment evaluation of rapid palatal expansion. Angle Orthodont. 1980;50:189-217.

66. Hahn GW. Edward Hartley Angle (1855 - 1930). Am J Orthod. 1965;51:529-35.

67. Handelman CS. Nonsurgical rapid maxillary alveolar expansion in adults: a clinical evaluation. Angle Orthod. 1997;67:291-306.

68. Handelman CS, Wang L, BeGole EA, Haas AJ. Nonsurgical Rapid Maxillary Expansion in Adults: Report on 47 Cases Using the Haas Expander. Angle Orthod. 2000;70:129-44.

69. Hayakawa $Y$, Shibuya $H$, Ota $Y$, Kuroyanagi $K$. Radiation dosage reduction in general dental practice using intraoral radiographic systems. Bull Tokyo Dent Coll. 1997;38:21-5.

70. Inoue N, Ohyama K, Ishiguro K, Azumo M, Ozaki T, Kosugi R. Radiographic observation of rapid expansion of human maxilla. Bull Tokyo Med Dent Univ. 1970;17:149-61.

71. Izuka EN, Feres MF, Pignatari SS. Immediate impact of rapid maxillary expansion on upper airway dimensions and on the quality of life of mouth breathers. Dental Press J Orthod. 2015;20:43-9.

72. Jawad MM, Husein A, Azlina A, Alam MK, Hassan R, Shaari R. Effect of $940 \mathrm{~nm}$ low-level laser therapy on osteogenesis in vitro. J Biomed Opt. 2013;18:128001-6.

73. Jenatschke $F$, Elsenberger $E$, Welte $H D$, Schlagenhauf $U$. Influence of repeated chlorhexidine varnish applications on mutans streptococci counts and caries increment in patients treated with fixed orthodontic appliances. J Orofac Orthop. 2001;62:36-45.

74. Joviliano $\quad P$, Junqueira $\quad A A$, Stabile $\quad A C$, Leite-Panissi $\quad C R$, Rocha $M J$. Rapid maxillary expansion causes neuronal activation in brain structures of rats. Brain Res Bull. 2008;76:396-401.

75. Junqueira LC, Carneiro J. Histologia Básica: Texto e Atlas. São Paulo: Guanabara Koogan; 2013.

76. Katchburian E, Arana V. Histologia e Embriologia Oral. São Paulo: Guanabara Koogan; 2012.

77. Korkhaus, G. Present Orthodontic thought in Germany. Amer J Orthodont. 1960;46:187206.

78. Kusnoto B, Evans CA. A reliability of a 3D surface laser scanner for orthodontics applications. Am J Orthod Dentofacial Orthop. 2002;122:342-8.

79. Lacerda ÂS, Hanashiro FS, de Sant'Anna GR, Steagall Júnior W, Barbosa PS, De SouzaZaroni WC. Effects of near infrared laser radiation associated with photoabsorbing cream in preventing white spot lesions around orthodontic brackets: an in vitro study. Photomed Laser Surg. 2014;32:686-93. 
80. Lagravère MO, Carey J, Heo G, Toogood RW, Major PW. Transverse, vertical, and anteroposterior changes from bone-anchored maxillary expansion vs traditional rapid maxillary expansion: A randomized clinical trial. Am J Orthod Dentofacial Orthop. 2010;137:304.e1-304.e12.

81. Lagravère MO, Heo G, Major PW, Flores-Mir C. Meta-analysis of immediate changes with rapid maxillary expansion treatment. J Am Dent Assoc. 2006;137:44-53.

82. Lagravère MO, Major PW, Flores-Mir C. Long-term Skeletal Changes with Rapid Maxillary Expansion: A Systematic Review. Angle Orthod. 2005;75:1046-52.

83. Lilge L, Tierney K, Nussbaum E. Low-level laser therapy for wound healing: feasibility of wound dressing transillumination. J Clin Laser Med Surg. 2000;18:235-40.

84. Lim HM, Lew KK, Tay DK. A clinical investigation of the efficacy of low level laser therapy in reducing orthodontic postadjustment pain. Am J Orthod Dentofacial Orthop. 1995;108:614-22.

85. Lione R, Ballanti F, Franchi L, Baccetti T, Cozza P. Treatment and posttreatment skeletal effects of rapid maxillary expansion studied with low-dose computed tomography in growing subjects. Am J Orthod Dentofacial Orthop. 2008;134:389-92

86. Lione $R$, Franchi L, Cozza P. Does rapid maxillary expansion induce adverse effects in growing subjects? Angle Orthod. 2013;83:172-82.

87. Luebbert J, Ghoneima A, Lagravère MO. Skeletal and dental effects of rapid maxillary expansion assessed through three-dimensional imaging: A multicenter study. Int Orthod. 2016;14:15-31.

88. Lundström F, Hamp SE. Effect of oral hygiene education on children with and without subsequent orthodontic treatment. Scand J Dent Res. 1980;88:53-9.

89. Luers JC, Petry-Schmelzer JN, Hein WG, Gostian AO, Hüttenbrink KB, Beutner D. Fragmentation of salivary stones with a 980nm diode laser. Auris Nasus Larynx. 2014;41:76-80.

90. Macri RT, de Lima FA, Bachmann L, Galo R, Romano FL, Borsatto MC, Matsumoto MA. $\mathrm{CO} 2$ laser as auxiliary in the debonding of ceramic brackets. Macri Lasers Med Sci. 2015;30:1835-41.

91. Maia LG, Monini Ada C, Jacob HB, Gandini LG Jr. Maxillary ulceration resulting from using a rapid maxillary expander in a diabetic patient. Angle Orthod. 2011;81:546-50.

92. Maiman TH. Stimulated optical radiation in ruby. Nature. 1960;187:493-4.

93. Mansour S, Ajdaharian J, Nabelsi T, Chan G, Wilder-Smith P. Comparison of caries diagnostic modalities: A clinical study in 40 subjects. Lasers Surg Med. 2016 Mar 21. doi: $10.1002 / \mathrm{lsm} .22460$. [Epub ahead of print]

94. Martins MCF, Costa C, Abrão J, Borri ML. Rapid maxillary expansion: radiographic analysis of the midpalatal suture density and its correlation in the osteogenesis stages by digital image. Rev Dent Press Ortodon Ortop Facial. 2009;14:381-9. 
95. Matos DS. Influência da fonte de luz e do tempo de polimerização na resistência ao cisalhamento da colagem de bráquetes metálicos e cerâmicos [Monografia]. São Paulo: Associação Odontológica de Ribeirão Preto; 2013b.

96. Matos DS. Resistência ao cisalhamento de bráquetes ortodônticos cerâmicos colados com diferentes compósitos e irradiados com laser de $\mathrm{CO}_{2}$ [Dissertação]. São Paulo: Faculdade de Odontologia de Ribeirão Preto; 2013a.

97. Matsuoka E, Santos DAG, Marchesan IQ. Speech-language and swallowing pattern in functional orthopaedic device's users with and without the use of the device. Rev CEFAC. 2006;8:198-204.

98. McNamara JA. In: Graber TM, Vanarsdall, RL. Ortodontia. Princípios e Técnicas Atuais. São Paulo: Elsevier; 1996. p. 466-97.

99. McNamara JA. Maxillary transverse deficiency. Am J Ortho Dentofacial Orthop 2000;117:567-70.

100. McNamara JA, Baccetti T, Franchi L, Herberger TA. Rapid maxillary expansion followed by fixed appliances: a long-term evaluation of changes in arch dimensions. Angle Orthod. 2003;73:344-53.

101. McNamara JA, Brudon WL. Bonded rapid maxillary expansion Appliances. In: Orthodontic and orthopedic treatment in the mixed dentition. Ann Arbor: Needham Press; 1993. p.145-9.

102. Melsen BA. A histological study of the influence of sutural morphology and skeletal maturation on rapid palatal expansion in children. Trans Eur Orthod Soc. 1972;1:499507.

103. Morton LM, Dover JS, Phillips TJ, Krakowski AC, Uebelhoer NS. Treatment of ulcers with ablative fractional lasers. Semin Cutan Med Surg. 2015;34:37-41.

104. Mottola CA. Measurement strategies: the visual analogue scale. Decubitus. 1993;6:568.

105. Moyers RE. Ortodontia. Rio de Janeiro: Guanabara Koogan; 1991.

106. Mutinelli S, Cozzani M, Manfredi M, Bee M, Siciliani G. Dental arch changes following rapid maxillary expansion. Eur J Orthod. 2008;30:469-76.

107. Navarro PR, de Assis GB, Souza LL, Macluf Filho E, Azenha CR, Tessitore A. Changes in oral functions in presence of fixed orthodontic appliances with features intraoral. Rev CEFAC. 2013;15:1281-90.

108. Needleman $\mathrm{HL}$, Hoang CD, Allred E, Hertzberg J, Berde C. Reports of pain by children undergoing rapid palatal expansion. Pediatr Dent. 2000;22:221-6.

109. Pejcic A, Kojovic D, Kesic L, Obradovic R. The effects of low level laser irradiation on gingival inflammation. Photomed Laser Surg. 2010;28:69-74.

110. Perillo L, De Rosa A, Iaselli F, d'Apuzzo F, Grassia V, Cappabianca S. Comparison between rapid and mixed maxillary expansion through an assessment of dento-skeletal effects on posteroanterior cephalometry. Prog Orthod. 2014;15:1-8. 
111. Pinheiro ALB, Brugnera Júnior A, Zanin FAA. Aplicação do Laser na Odontologia. São Paulo: Santos; 2010.

112. Pinto CMS, Ferreira JTL, Matsumoto MAN, Borsatto MC, Silva RAB, Romano FL. Evaluation of different LED light-curing devices for bonding metallic orthodontic brackets. Braz Dent J. 2011;22:249-53.

113. Pretel H, Lizarelli RF, Ramalho LT. Effect of low-level laser therapy on bone repair: histological study in rats. Lasers Surg Med. 2007;39:788-96.

114. Proffit WR, Fields HW, Sarver DM. Ortodontia contemporânea. Rio de Janeiro: Elsevier; 2007.

115. Rajesh S, Koshi E, Philip K, Mohan A. Antimicrobial photodynamic therapy: An overview. J Indian Soc Periodontol. 2011;15:323-7.

116. Ring ME. Dentistry: an illustrated history. New York: Abradale Press; 1993.

117. Romeo A, Canal F, Roma M, De La Higuera B, Ustrell JM, Von Arx JD. Holograms in orthodontics: a universal system for the production, development, and illumination of holograms for the storage and analysis of dental casts. Am J Orthod Dentofacial Orthop. 1995; 108:443-7.

118. Saito S, Shimizu N. Stimulatory effects of low-power laser irradiation on bone regeneration in midpalatal suture during expansion in the rat. Am J Orthod Dentofacial Orthop. 1997;111:525-32.

119. Santiago VC, Piram A, Fuziy A. Effect of soft laser in bone repair after expansion of the midpalatal suture in dogs. Am J Orthod Dentofacial Orthop. 2012;142:615-24.

120. Schuster G, Borel-Scherf I, Schopf PM. Frequency of and complications in the use of RPE appliances--results of a survey in the Federal State of Hesse, Germany. J Orofac Orthop. 2005;66:148-61.

121. Simões FXPC; Araújo TM, Bittencourt MAV. Evaluation of osseous maturation in the midpalatal suture, after maxillary rapid expansion, using digitalized image. $\mathrm{R}$ Dental Press Ortodon Ortop Facial. 2003;8:59-67.

122. Stangler LP, Romano FL, Shirozaki MU, Galo R, Afonso AM, Borsatto MC, Matsumoto MA. Microhardness of enamel adjacent to orthodontic brackets after $\mathrm{CO} 2$ laser irradiation and fluoride application. Braz Dent J. 2013;24:508-12.

123. Stern RH, Sogannaes RF. Laser beam on dental hard tissue. J Dent Res. 1964;43:873.

124. Stewart $L$, Powell GL, Wright $S$. Hydroxyapatite attached by laser: A potential sealant for pits and fissures. Oper Dent. 1985;10:2-5.

125. Strauss RA. Laser in oral and maxillofacial surgery. Dent Clin North Am. 2000;44:85173.

126. Sulieman M. An overview of the use of laser in general dental practice: Laser wavelenghts soft and hard tissue clinical applications. Dent Update. 2005;32:286-8. 
127. Ten Cate AR, Freeman E, Dicknson JB. Sutural development: structure and its response to rapid expansion. Amer J Orthodont. 1977;71:622-36.

128. Tortamano A, Lenzi DC, Haddad AC, Bottino MC, Dominguez GC, Vigorito JW. Low-level laser therapy for pain caused by placement of the first orthodontic archwire: $A$ randomized clinical trial. Am J Orthod Dentofacial Orthop. 2009;136:662-7.

129. Turhani D, Scheriau M, Kapral D, Benesch T, Jonke E, Bantleon HP. Pain relief by single low-level laser irradiation in orthodontic patients undergoing fixed appliance therapy. Am J Orthod Dentofacial Orthop. 2006;130:371-7.

130. Ugolini A, Doldo T, Ghislanzoni LT, Mapelli A, Giorgetti R, Sforza C. Rapid palatal expansion effects on mandibular transverse dimensions in unilateral posterior crossbite patients: a three-dimensional digital imaging study. Prog Orthod. 2016;17:1-7.

131. Velázquez $P$, Benito $E$, Bravo LA. Rapid maxillary expansion. A study of the long-term effects. Am J Orthod Dentofacial Orthop. 1996;109:361-7.

132. Verma SK, Maheshwari S, Singh RK, Chaudhari PK. Laser in dentistry: An innovative tool in modern dental practice. Natl J Maxillofac Surg. 2012;3:124-32.

133. Versteeg $\mathrm{CH}$, Sanderink GC, van der Stelt PF. Efficacy of digital intra-oral radiography in clinical dentistry. J Dent. 1997;25:215-24.

134. Vilella, OV Development of Orthodontics in Brazil and in the world. R Dental Press Ortodon Ortop Facial. 2007;12:131-56.

135. Wahl, N. Orthodontics in 3 millennia. Chapter 2: Entering the modern era. Am. J. Orthod. Dentofacial Orthop. 2005;127:510-15.

136. Weinberger, BS. Orthodontics: an historical review of its origin and evolution. St. Louis: C. V. Mosby; 1926.

137. Weissheimer A, de Menezes LM, Mezomo M, Dias DM, de Lima EM, Rizzatto SM. Immediate effects of rapid maxillary expansion with Haas-type and hyrax-type expanders: a randomized clinical trial. Am J Orthod Dentofacial Orthop. 2011;140:36676

138. Wertz RA. Changes in nasal airflow incident to rapid maxillary expansion. Angle Orthod. 1968;38:1-11.

139. White L. Early orthodontic intervention. Am J Orthod Dentofacial Orthop. 1998;113:248.

140. Wigdor HA, Walsh JT, Featherstone JD, Visuri SR, Fried D, Waldvogel JL. Laser in dentistry. Lasers Surg Med. 1995;16:103-33.

141. Wong CA, Sinclair PM, Keim RG, Kennedy DB. Arch dimension changes from successful slow maxillary expansion of unilateral posterior crossbite. Angle Orthod. 2011;81:61623.

142. Yassaei S, Shahraki N, Aghili H, Davari A. Combined effects of Er: YAG laser and casein phosphopeptide-amorphous calcium phosphate on the inhibition of enamel demineralization: An in vitro study. Dent Res J (Isfahan). 2014;11:193-8. 
143. Yoshiura K, Kawazu T, Chikui T, Tatsumi M, Tokumori K, Tanaka T, Kanda S. Assessment of image quality in dental radiography, part 1. Oral Surg Oral Med Oral Pathol Oral Radiol Endod. 1999a;87:115-22.

144. Yoshiura K, Kawazu T, Chikui T, Tatsumi M, Tokumori K, Tanaka T, Kanda S. Assessment of image quality in dental radiography, part 2: optimum exposure conditions for detection of small mass changes in 6 intraoral radiography systems. Oral Surg Oral Med Oral Pathol Oral Radiol Endod. 1999b;87:123-9. 
Anexas 
ANEXo 1 - COMITÊ de ÉTICA

\section{FACULDADE DE ODONTOLOGIA DE RIBEIRÃO Slotoforme PRETO/FORP/USP}

\section{PARECER CONSUBSTANCIADO DO CEP}

\section{DADOS DO PROJETO DE PESQUISA}

Título da Pesquisa: Avaliação in vivo da ação osteoindutora do laser de baixa potência na formação óssea da sutura palatina mediana após expansão rápida da maxila

Pesquisador: Fábio Lourenço Romano

Área Temática:

Versão: 1

CAAE: 50417215.4 .0000 .5419

Instituição Proponente: Universidade de Sao Paulo

Patrocinador Principal: Financiamento Próprio

\section{DADOS DO PARECER}

Número do Parecer: 1.338 .908

\section{Apresentação do Projeto:}

O diagnóstico e intervenção precoce em maloclusões onde o paciente apresenta mordida cruzada posterior esquelética ou atresia de maxila é

extremamente importante sendo que o crescimento transversal dos arcos dentários é o primeiro a cessar. $\mathrm{O}$ tratamento de escolha para estas

maloclusões é o uso de aparelhos disjuntores com a finalidade de aumentar as dimensões do arco superior. que pode ser demorado e trazer algum

desconforto ao paciente. Pesquisa relevante para a área da odontologia e ortodontia, apresenta referências bibliográficas atualizadas e os pesquisadores são plenamente habilitados para o desenvolvimento do projeto em tela. Serão selecionados 40 crianças divididos em 2 grupo $(n=20)$ sendo um Grupo Controle e outro Experimental. Todos os participantes da pesquisa deverão entre outros critérios de inclusão, apresentar atresia de maxila para que seja executado o tratamento com o aparelho Disjuntor Hyrax. Os particpantes do Grupo Experimental serão submetidos a aplicações periódicas de Laser de Diodo com $808 \mathrm{~nm}$ cerca de $100 \mathrm{~mW}$,

já para os participantes do Grupo Controle as aplicações do Laser serão no modo Standby para caracterizar 0 efeito placebo. Durante o tratamento,

os participantes da pesquisa de ambos os grupos realizarão exames radiográficos digitais para

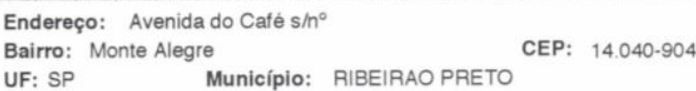




\section{FACULDADE DE ODONTOLOGIA DE RIBEIRÃO PRETO/FORP/ USP}

Continuaçăo đo Parecer: 1.338.908

posterior comparação entre eles utilizando o

programa Image J 1.50b. A influência do Laser na sensação dolorosa entre os grupos será avaliada por meio de Escala Visual de Dor.

\section{Objetivo da Pesquisa:}

Objetivo Primário:

O objetivo deste estudo será avaliar a ação osteoindutora do laser de baixa potência na sutura palatina mediana de pacientes com atresia maxilar

esquelética submetidos à expansão rápida da maxila.

Objetivo Secundário:

Avaliar as alterações pós-disjunção nos arcos superior e inferior e a sensação dolorosa durante o procedimento de expansão rápida da maxila com aparelho disjuntor Hyrax.

\section{Avaliação dos Riscos e Benefícios:}

Os procedimentos executados durante a pesquisa não causarão nenhum desconforto ao participante da pesquisa. Não haverá dor ou danos em

nenhum momento da aplicação do Laser por isso, os riscos em participar desta pesquisa serão mínimos. Durante as tomadas radiográficas, 0

participante da pesquisa estará devidamente protegido com avental de chumbo e colar protetor de tireoide, conforme as orientações especificas da

Portaria do Ministério da Saúde/Serviço de Vigilância Sanitária n453, de 1 de junho de 1998 D.O.U. 02/06/98, que aprova o regulamento técnico

que estabelece as diretrizes básicas de proteção radiológica em radiodiagnóstico médico e odontológico. Beneficios:

Os participantes desta pesquisa terão um acompanhamento odontológico com maior cuidado. Sua higiene bucal será monitorada afim de que o uso

do aparelho não traga nenhum risco ou aumento da atividade de cárie para o participante. Quando a Odontopediatra que o acompanhar achar

necessário, serão realizados procedimentos de profilaxia e aplicação de flúor. Caso o participante da pesquisa apresente alguma cárie ou qualquer

outro problema odontológico que necessite de atenção, este será encaminhado para tratamento o mais rápido possivel a fim de evitar 0

agravamento da situação. Após o tratamento de expansão rápida da maxila, os participantes da

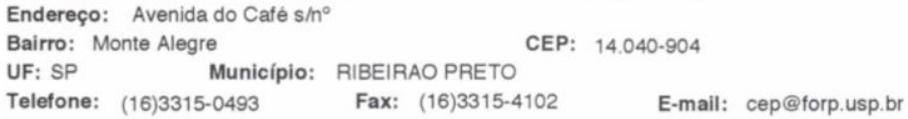




\section{FACULDADE DE ODONTOLOGIA DE RIBEIRÃO PRETO/FORP/USP}

Continuação do Parecer: 1.338 .908

pesquisa continuarão o tratamento ortodôntico de

acordo com o tipo de maloclusão apresentada.

Comentários e Considerações sobre a Pesquisa:

O projeto de pesquisa é relevante, o uso do laser e todas as suas possiveis aplicações é um estudo atual na odontologia, projeto tem fundamentação científica adequada e os pesquisadores são plenamente capazes de realizá-las.

Considerações sobre os Termos de apresentação obrigatória:

Adequados. Cronograma, orçamento, TCLE, termo de assentimento, declaração de infraestrutura.

\section{Recomendações:}

Aprovado

Conclusões ou Pendências e Lista de Inadequações:

Aprovado

Considerações Finais a critério do CEP:

Conforme deliberado na $186^{\text {a }}$ Reunião Ordinária do CEP, realizada em 25/11/2015.

Este parecer foi elaborado baseado nos documentos abaixo relacionados:

\begin{tabular}{|c|c|c|c|c|}
\hline Tipo Documento & Arquivo & Postagem & Autor & Situação \\
\hline $\begin{array}{l}\text { Informações Básicas } \\
\text { do Projeto }\end{array}$ & $\begin{array}{l}\text { PB_INFORMAÇŌES_BÁSICAS_DO_P } \\
\text { ROJETO 598098.pdf }\end{array}$ & $\begin{array}{c}19 / 10 / 2015 \\
18: 23: 31 \\
\end{array}$ & & Aceito \\
\hline Folha de Rosto & folha_rosto.pdf & $\begin{array}{c}19 / 10 / 2015 \\
18: 22: 30 \\
\end{array}$ & $\begin{array}{l}\text { Fábio Lourenço } \\
\text { Romano } \\
\end{array}$ & Aceito \\
\hline $\begin{array}{l}\text { TCLE / Termos de } \\
\text { Assentimento / } \\
\text { Justificativa de } \\
\text { Ausência }\end{array}$ & Termo_Assentimento.docx & $\begin{array}{c}06 / 10 / 2015 \\
20: 23: 16\end{array}$ & $\begin{array}{l}\text { Fábio Lourenço } \\
\text { Romano }\end{array}$ & Aceito \\
\hline $\begin{array}{l}\text { TCLE / Termos de } \\
\text { Assentimento / } \\
\text { Justificativa de } \\
\text { Ausência }\end{array}$ & Termo_Consentimento.docx & $\begin{array}{c}06 / 10 / 2015 \\
20: 23: 06\end{array}$ & $\begin{array}{l}\text { Fábio Lourenço } \\
\text { Romano }\end{array}$ & Aceito \\
\hline $\begin{array}{l}\text { Projeto Detalhado / } \\
\text { Brochura } \\
\text { Investigador }\end{array}$ & Projeto_detalhado.docx & $\begin{array}{c}06 / 10 / 2015 \\
20: 22: 47\end{array}$ & $\begin{array}{l}\text { Fábio Lourenço } \\
\text { Romano }\end{array}$ & Aceito \\
\hline $\begin{array}{l}\text { Declaração de } \\
\text { Instituição e } \\
\text { Infraestrutura } \\
\end{array}$ & Infraestrutura2.pdf & $\begin{array}{c}26 / 09 / 2015 \\
12: 29: 10\end{array}$ & $\begin{array}{l}\text { Fábio Lourenço } \\
\text { Romano }\end{array}$ & Aceito \\
\hline $\begin{array}{l}\text { Declaração de } \\
\text { Instituicão e }\end{array}$ & Infraestrutura.pdf & $\begin{array}{c}26 / 09 / 2015 \\
12: 28: 58 \\
\end{array}$ & $\begin{array}{l}\text { Fábio Lourenço } \\
\text { Romano }\end{array}$ & Aceito \\
\hline
\end{tabular}

Endereço: Avenida do Café $s / \mathrm{n}^{\circ}$

Bairro: Monte Alegre CEP: $14.040-904$

UF: SP Município: RIBEIRAO PRETO

Telefone: (16)3315-0493 Fax: (16)3315-4102 E-mail: cep@forp.usp.br 


\section{FACULDADE DE \\ ODONTOLOGIA DE RIBEIRÃO \\ PRETO/ FORP/ USP}

Continuação do Parecer: 1.338.908

\begin{tabular}{|l|l|c|l|l|}
\hline Infraestrutura & Infraestrutura.pdf & $26 / 09 / 2015$ \\
$12: 28: 58$ & $\begin{array}{l}\text { Fábio Lourenço } \\
\text { Romano }\end{array}$ & Aceito \\
\hline
\end{tabular}

Situação do Parecer:

Aprovado

Necessita Apreciação da CONEP:

Não

RIBEIRAO PRETO, 26 de Novembro de 2015

Assinado por:

Simone Cecilio Hallak Regalo

(Coordenador)

Endereço: Avenida do Café $\mathrm{s} / \mathrm{n}^{\circ}$

Bairro: Monte Alegre

UF: SP Município: RIBEIRAO PRETO

Telefone: (16)3315-0493 Fax: (16)3315-4102

CEP: $14.040-904$

Fax: (16)3315-4102 E-mail: cep@forp.usp.br 


\section{UNIVERSIDADE DE SÃO PAULO \\ FACULDADE DE ODONTOLOGIA DE RIBEIRÃO PRETO DEPARTAMENTO DE CLÍNICA INFANTIL}

Convido

você

RG

, responsável por

participar da pesquisa "Avaliação in vivo da ação osteoindutora do laser de baixa potência na formação óssea da sutura palatina mediana após expansão rápida da maxila", sob a responsabilidade dos pesquisadores Prof. Dr. Fábio Lourenço Romano, Telefone para contato (16) 33153995 / 33154146, e-mail: fabioromano@forp.usp.br e Denise de Souza Matos, Telefone para contato (16) 981372525 e-mail: denisesouzamatos@yahoo.com.br.

\section{Por que está sendo feita a pesquisa (objetivos)?}

Este trabalho tem a finalidade (objetivo) de avaliar a formação de osso ocorrida após aplicação do Laser de baixa potência (aparelho que emite luz da cor vermelha) na sutura palatina mediana ("céu da boca") dos participantes da pesquisa com atresia maxilar (crescimento menor da maxila - arco dentário superior da boca), mordida cruzada posterior (dente em posição cruzada na região posterior dos arcos dentários) ou palato ogival ("céu da boca" fundo) e que foram submetidos à expansão rápida da maxila (uso do aparelho disjuntor Hyrax que separa os dois ossos do arco superior da boca).

\section{Por que meu filho é importante nesta pesquisa?}

Seu(Sua) filho(a) apresenta as condições necessárias para a realização da pesquisa, pois ele possui um problema nos dentes que pode ser corrigido utilizando o aparelho que deixa o arco superior maior. Depois de usar este aparelho, você não terá mais este problema no arco superior.

\section{O que tenho que fazer para que meu filho(a) participe da pesquisa?}

Se você concordar que seu filho(a) participe, um dentista irá acompanhar o tratamento ortodôntico do seu filho(a) e fará aplicações de Laser (aparelho que emite luz na cor vermelha) no céu da boca. A luz será aplicada durante 1 minuto em seis pontos do céu da boca. A aplicação em cada ponto será de 10 segundos. Seu(Sua) filho(a) será acompanhado(a) por 6 meses e no $1^{\circ}, 2^{\circ}, 3^{\circ}$ e $6^{\circ}$ meses, nova radiografia do arco superior da boca será tirada. Esta pesquisa terá dois grupos de tratamento. Em todos os grupos os participantes irão utilizar o aparelho fixo no arco superior da boca. Em um grupo o laser (luz) será aplicado e no outro grupo o laser (luz) não será aplicado. Seu(Sua) filho(a) poderá ser tratado em qualquer um dos grupos. Caso ele(ela) fique no grupo sem aplicação da luz, não acontecerá nenhum problema, porque o aparelho para corrigir a alteração do arco superior da boca e dos dentes será utilizado e ativado, corrigindo, dessa forma, o seu problema.

\section{Existirá algum risco/desconforto para meu filho(a) em participar na pesquisa?}

O tratamento não causará nenhum desconforto a seu(sua) filho(a). Não haverá dor ou danos em nenhum momento da aplicação do Laser (luz) por isso. Seu(Sua) filho(a) sentirá uma pressão leve toda vez que o aparelho for aberto. Na hora de tirar a radiografia, seu(sua) filho(a) estará devidamente protegido com avental de chumbo e colar protetor de tireoide, conforme as orientações específicas da Portaria do Ministério da Saúde/Serviço de Vigilância Sanitária n0453, de 1 de junho de 1998 Diário Oficial da União 02/06/98, que aprova o regulamento técnico que estabelece as diretrizes básicas de proteção radiológica em radiodiagnóstico médico e odontológico. Os desconfortos que irão ocorrer serão na escolha e adaptação de anéis que serão colocados nos dentes de trás no arco superior da boca. 


\section{Quais são os benefícios desta pesquisa para meu filho(a)?}

Caso concorde que seu(sua) filho(a) participe da pesquisa, ele(ela) terá um acompanhamento com um dentista durante todo o tratamento. Sua higiene bucal será acompanhada para que o uso do aparelho não traga nenhum risco ou aumento do aparecimento de cárie para o participante da pesquisa. Quando o(a) dentista achar necessário, será feito limpeza da boca e aplicação de flúor. Caso seu(sua) filho(a) apresente alguma cárie ou qualquer outro problema odontológico que necessite de atenção, um dentista irá tratar seus dentes o mais rápido possível.

\section{O que acontecerá se eu não quiser que meu filho(a) participe desta pesquisa?}

Absolutamente nada! A participação do seu(sua) filho(a) é livre e acontecerá somente se você concordar que ele(ela) participe. Caso você não queira que seu(sua) filho(a) participe, o tratamento ortodôntico continuará da mesma forma, sem nenhum prejuízo. Se você optar para que seu(sua) filho(a) participe da pesquisa e durante a realização da pesquisa você não quiser mais que ele(ela) participe, garantimos à criança e a você o direito de desistir e ela não sofrerá nenhuma penalização. Seu tratamento será realizado sem nenhum prejuízo.

Nós, pesquisadores responsáveis pela pesquisa, garantimos a você o direito de esclarecimentos de dúvidas a qualquer momento, durante e após o término da pesquisa. Caso aconteça algum problema durante a realização da pesquisa prestaremos atendimento até a solução do problema, pelo tempo que for necessário. Caso ocorra algum dano devido à sua participação na pesquisa, você será indenizado por isso. Você não terá gastos para participar desta pesquisa. Caso seja necessário o seu comparecimento em dias diferentes ao atendimento clínico relativo ao seu tratamento dentário, os pesquisadores irão restituir seus gastos. Você terá tempo suficiente para decidir se quer participar da pesquisa. Você pode levar este Termo de Consentimento para casa para poder conversar com amigos e parentes e então decidir se irá participar ou não da pesquisa. Garantimos a você que o material e os dados obtidos na pesquisa serão utilizados exclusivamente para ganhar conhecimento que irá ajudar no tratamento de mais pessoas; garantimos também que a pesquisa só será interrompida somente após análise e manifestação, por parte do Sistema CEP/CONEP/CNS/MS que a aprovou, das razões dessa descontinuidade, a não ser em casos de justificada urgência em benefício de seus participantes. Na divulgação dos resultados obtidos nesta pesquisa garantimos o sigilo e confidencialidade de suas informações. Nenhum dado do(a) seu(sua) filho(a) será divulgado. Somente serão divulgadas as informações relacionadas ao tratamento que foi feito no(a) seu(sua) filho(a).

Este Termo de Consentimento Livre e Esclarecido foi construído em duas vias, você e nós, pesquisadores responsáveis, deveremos assinar a última folha e rubricar as outras. Uma via deste termo será arquivada pelos pesquisadores e a outra você deverá guardar. Os CEPs são colegiados interdisciplinares e independentes, de relevância pública, de caráter consultivo, deliberativo e educativo, criados para defender os interesses dos participantes da pesquisa em sua integridade e dignidade e para contribuir no desenvolvimento da pesquisa dentro de padrões éticos. 0 horário de funcionamento é das 8 às 12 horas de 2a. à 6a. feira e o telefone para contato 33150493.

\section{Prof. Dr. Fábio Lourenço Romano Pesquisador Responsável}

\section{C.D. Denise de Souza Matos Pesquisador Participante}

Entendi o que foi explicado acima, por isso, concordo em participar desta pesquisa.

Ribeirão Preto

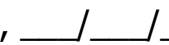




\section{AneXo 3 - Termo de Assentimento 7 a 12 Anos \\ UNIVERSIDADE DE SÃO PAULO
FACULDADE DE ODONTOLOGIA DE RIBEIRÃO PRETO DEPARTAMENTO DE CLÍNICA INFANTIL}

Convido você

a participar da pesquisa "Avaliação in vivo da ação osteoindutora

do laser de baixa potência na formação óssea da sutura palatina mediana após expansão rápida da maxila", sob a responsabilidade dos pesquisadores Prof. Dr. Fábio Lourenço Romano, Telefone para contato (16) 33153995 / 33154146, e-mail: fabioromano@forp.usp.br e Denise de Souza Matos, Telefone para contato (16) 981372525, e-mail: denisesouzamatos@yahoo.com.br.

\section{Por que está sendo feita a pesquisa (objetivos)?}

Este trabalho irá avaliar a formação de osso mais rápida causada pelo Laser (aparelho que emite luz da cor vermelha) no "céu da boca" dos participantes da pesquisa que apresentam crescimento menor da maxila (parte onde ficam os dentes de cima na boca), mordida cruzada posterior (dente de cima está cruzado com o dente de baixo) e o "céu da boca" fundo e que usarão um aparelho para separar o arco superior, deixando ele mais largo, corrigindo a mordida cruzada e o céu da boca fundo.

\section{Por que é importante participar nesta pesquisa?}

Você estará participando da pesquisa, pois você tem um problema nos dentes que pode ser corrigido utilizando o aparelho que deixa o arco superior maior. Depois de usar este aparelho, você não terá mais este problema no arco superior.

\section{0 que tenho que fazer para participar da pesquisa?}

Se você concordar participar, um dentista que trabalha com criança irá acompanhar seu tratamento ortodôntico e fará aplicações de Laser (aparelho que emite luz na cor vermelha) no céu da boca. A luz será aplicada durante 1 minuto em seis pontos do céu da boca. A aplicação em cada ponto será de 10 segundos. Você será acompanhado(a) por 6 meses e no $1^{\circ}, 2^{\circ}, 3^{\circ}$ e $6^{\circ}$ meses, nova radiografia do arco superior da boca será tirada. Esta pesquisa terá dois grupos de tratamento. Em todos os grupos os participantes irão utilizar o aparelho fixo no arco superior da boca. Em um grupo o Laser (luz) será aplicado e no outro grupo o Laser (luz) não será aplicado. Você poderá ser tratado em qualquer um dos grupos. Caso você fique no grupo sem aplicação da luz, não acontecerá nenhum problema, porque o aparelho para corrigir a alteração do arco superior da boca e dos dentes será utilizado e ativado, corrigindo, dessa forma, o seu problema.

\section{Existirá algum risco/desconforto em participar na pesquisa?}

$\mathrm{O}$ tratamento não causará nenhum desconforto a você. Não haverá dor ou danos em nenhum momento da aplicação do Laser (luz) por isso. Você sentirá uma pressão leve toda vez que o aparelho for aberto. Na hora de tirar a radiografia, você estará devidamente protegido com avental de chumbo e colar protetor de tireoide, para não trazer problemas à sua saúde. Os desconfortos que irão ocorrer serão na escolha e adaptação de anéis que serão colocados nos dentes de trás no arco superior da boca.

\section{Quais são os benefícios desta pesquisa?}

Caso você concorde em participar da pesquisa, você terá um acompanhamento com um(a) dentista durante todo o tratamento. Sua higiene bucal será acompanhada para que o uso do aparelho não traga nenhum risco ou aumento do aparecimento de cárie para o participante da pesquisa. Quando o(a) dentista achar necessário, será feito limpeza da boca e aplicação de flúor. Caso você 
tenha alguma cárie ou qualquer outro problema nos dentes, um(a) dentista irá tratar seus dentes o mais rápido possível.

\section{O que acontecerá se eu não quiser participar desta pesquisa?}

Absolutamente nada! Você irá participar somente se quiser. Caso você não queira participar, o tratamento ortodôntico continuará da mesma forma, sem nenhum prejuízo. Se você participar da pesquisa e durante a realização desta pesquisa você não quiser mais participar, garantimos à você o direito de desistir e ninguém ficará bravo com você. Seu tratamento será realizado sem nenhum prejuízo.

Nós, pesquisadores responsáveis pela pesquisa, garantimos a você o direito de esclarecimentos de dúvidas a qualquer momento, durante e após o término da pesquisa. Caso aconteça algum problema durante a realização da pesquisa atenderemos você para resolver o problema, pelo tempo que for necessário. Caso ocorra algum dano devido à sua participação na pesquisa, você será indenizado por isso. Você não terá gastos para participar desta pesquisa. Caso seja necessário o seu comparecimento em dias diferentes ao atendimento durante o seu tratamento dentário, os pesquisadores irão restituir seus gastos. Você terá tempo suficiente para decidir se quer participar da pesquisa. Você pode levar este Termo de Assentimento para casa para poder conversar com amigos e parentes e então decidir se irá participar ou não da pesquisa. Garantimos a você que o material e os dados obtidos na pesquisa serão utilizados para ganhar conhecimento que irá ajudar no tratamento de mais pessoas; garantimos também que a pesquisa só será interrompida somente após análise e manifestação, por parte do Sistema CEP/CONEP/CNS/MS que a aprovou, a não ser em casos de justificada urgência em seu benefício. Na divulgação dos resultados obtidos nesta pesquisa garantimos o sigilo e confidencialidade de suas informações. Nenhum dado seu será divulgado. Somente serão divulgadas as informações relacionadas ao seu tratamento.

Este Termo de Assentimento foi construído em duas vias, você e nós, pesquisadores responsáveis, deveremos assinar a última folha e rubricar as outras. Uma via deste termo será arquivada pelos pesquisadores e a outra você deverá guardar. Os CEPs são colegiados interdisciplinares e independentes, de relevância pública, de caráter consultivo, deliberativo e educativo, criados para defender os interesses dos participantes da pesquisa em sua integridade e dignidade e para contribuir no desenvolvimento da pesquisa dentro de padrões éticos. O horário de funcionamento é das 8 às 12 horas de 2a. à 6a. feira e o telefone para contato é 33150493 .

\section{Prof. Dr. Fábio Lourenço Romano} Pesquisador Responsável

\section{C.D. Denise de Souza Matos \\ Pesquisador Participante}

Entendi o que foi explicado acima, por isso, concordo em participar desta pesquisa.

Ribeirão Preto, 


\section{ANEXO 4 - FOLHETO EXPLICATIVO}

UNIVERSIDADE DE SÃO PAULO

FACULDADE DE ODONTOLOGIA DE RIBEIRÃO PRETO - USP

ORTODONTIA

\section{INFORMAÇÕES SOBRE O PROCEDIMENTO DE DISJUNÇÃO}

\section{ATIVAÇÃo do APARELHO}

- No dia seguinte após a cimentação do aparelho ativar 1/4 de volta de manhã e outro à noite até a consulta de retorno. NÃO SE ESQUECER DE ATIVAR, pois, a ausência de ativação como recomendado pode ocasionar dor nos dentes;

- NÃO FALTAR ÀS CONSULTAS DE RETORNO!

- Serão necessárias 12 consultas de retorno.

\section{HIGIENE DO APARELHO}

- Utilizar escova macia para higienizar todas as partes do aparelho;

- Não deixar acumular alimento embaixo dos fios e do parafuso;

- Utilizar seringa sem agulha cheia de água e "esquichar" perto do aparelho após as principais refeições (café da manhã, almoço e jantar) para remover restos alimentares;

- Remover restos grandes de alimento com a escova ou com palito de dente com bastante cuidado para não machucar o palato (céu da boca).

\section{COMPLICAÇÕES OU FERIMENTOS}

- Em casos de sangramento do palato (céu da boca), dor forte ou quebra do aparelho, entrar em contato com a Dra. Denise imediatamente;

- pressão na linha média da face, leve tontura ou "embaralhamento" da visão podem ocorrer logo após a ativação e estes sintomas devem desaparecer em poucos minutos. Caso persistam, entrar em contato com a Dra. Denise.

** AS ORIENTAÇÕES DEVEM SER SEGUIDAS CORRETAMENTE PARA EVITAR FALHAS NO PROCEDIMENTO. 